Fall 1926

\title{
1926 Cedrus Yearbook
}

\section{Cedarville College}

Follow this and additional works at: https://digitalcommons.cedarville.edu/yearbooks

Part of the Higher Education Commons, Organizational Communication Commons, and the Public Relations and Advertising Commons

\section{Recommended Citation}

Cedarville College, "1926 Cedrus Yearbook" (1926). Yearbooks. 83.

https://digitalcommons.cedarville.edu/yearbooks/83

This Book is brought to you for free and open access by DigitalCommons@Cedarville, a service of the Centennial Library. It has been accepted for inclusion in Yearbooks by an authorized administrator of DigitalCommons@Cedarville. For more information, please contact digitalcommons@cedarville.edu. 


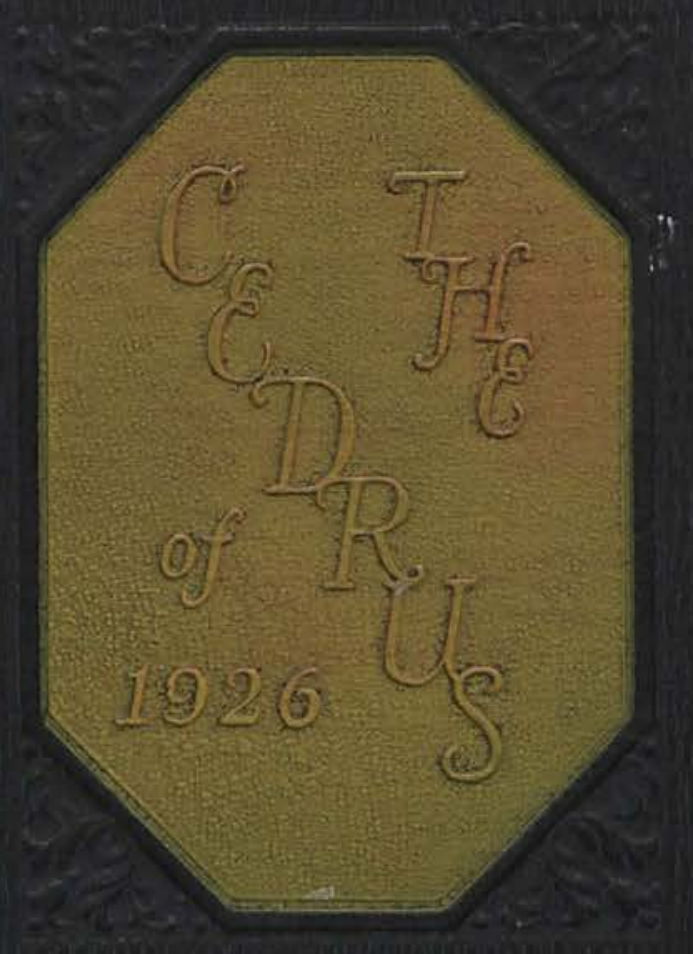




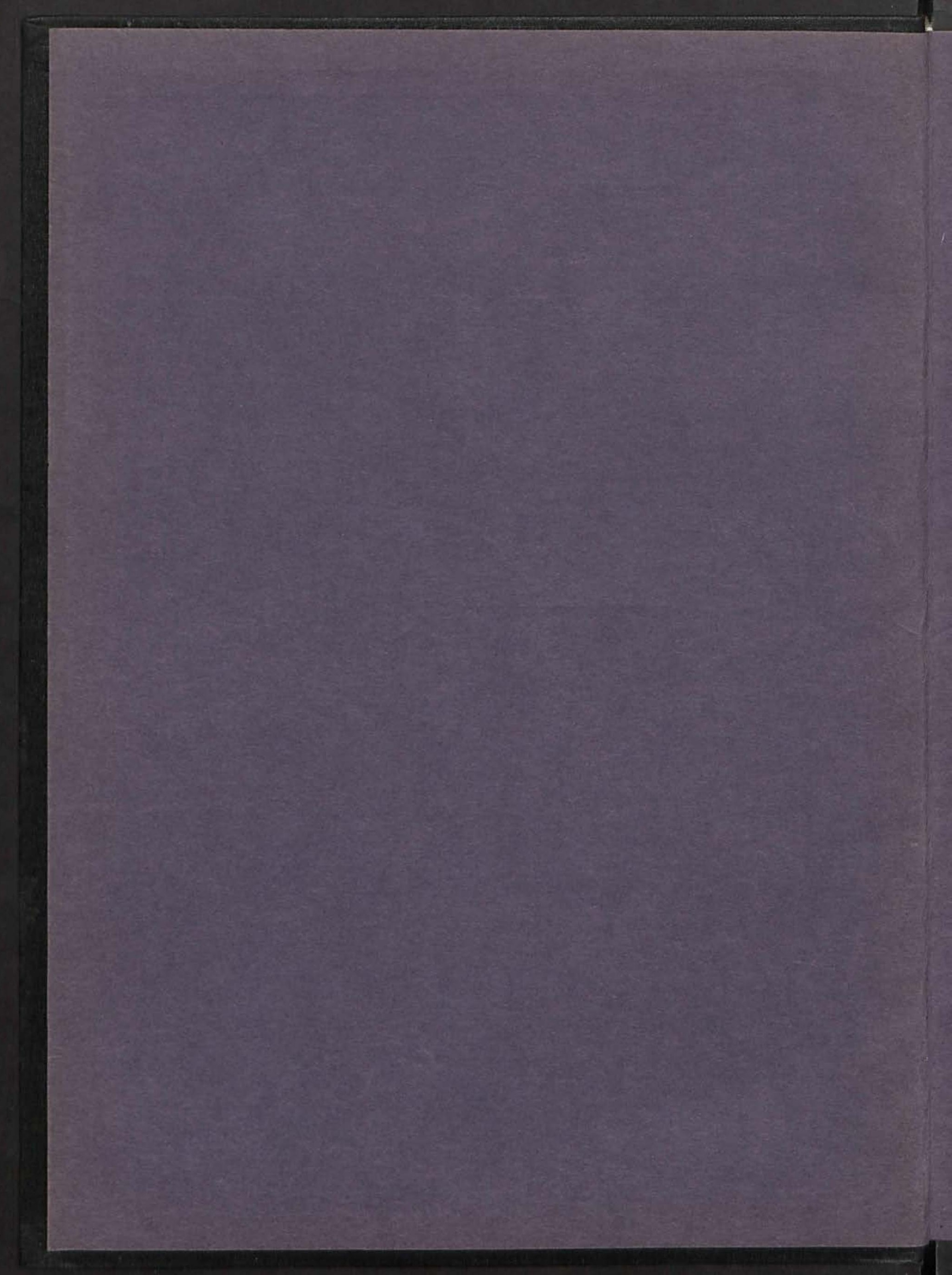




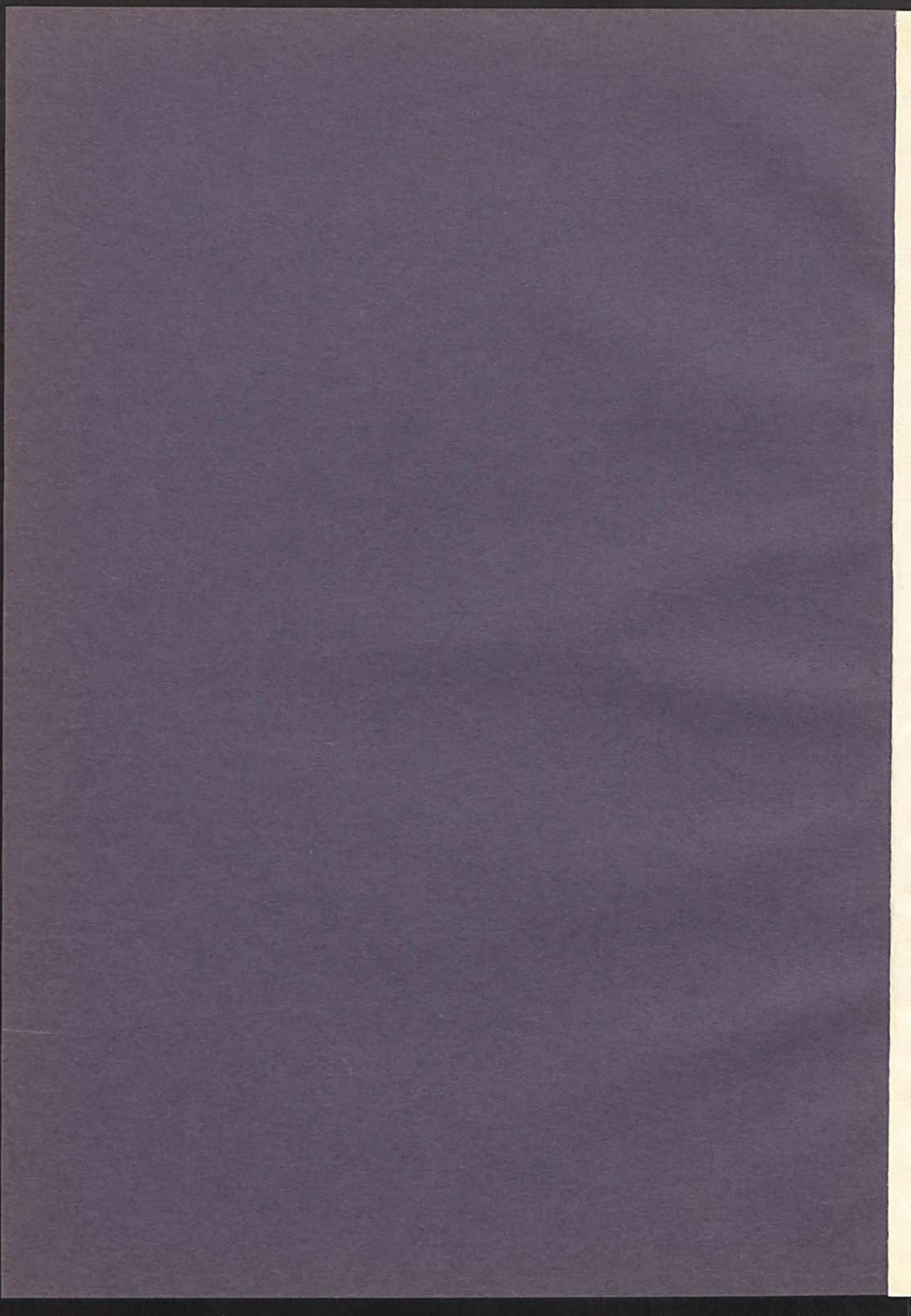





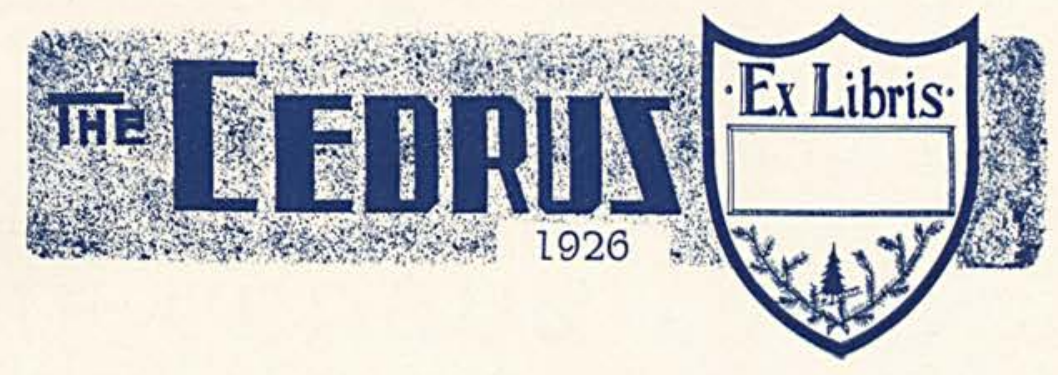


Compiled and edited for the students

of Cedarville College

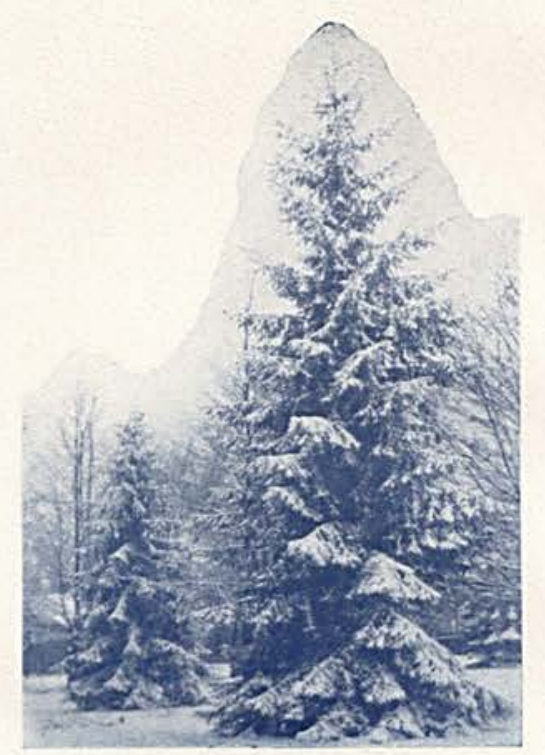

By the Cedrus Staff

of 1926. 


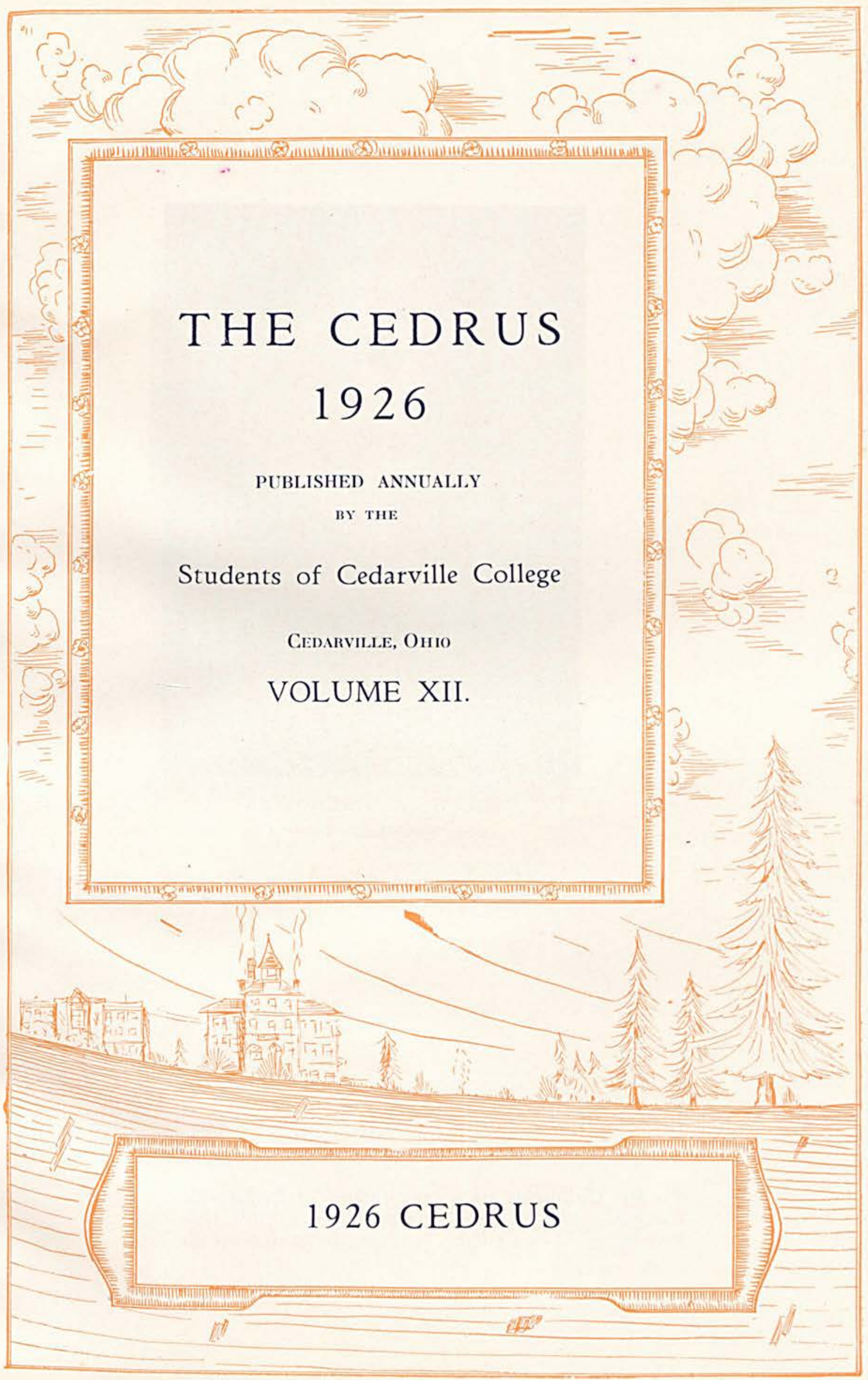




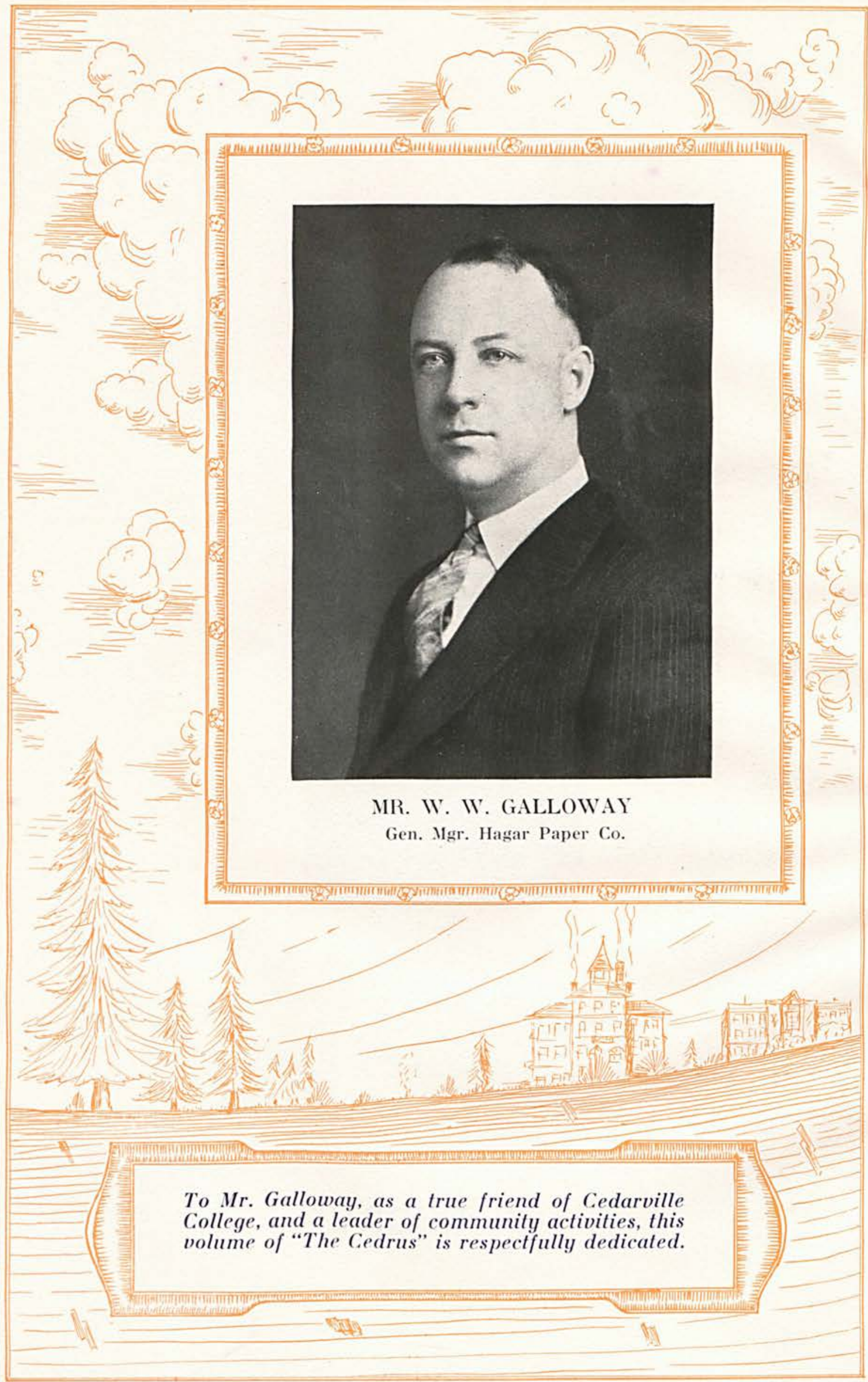




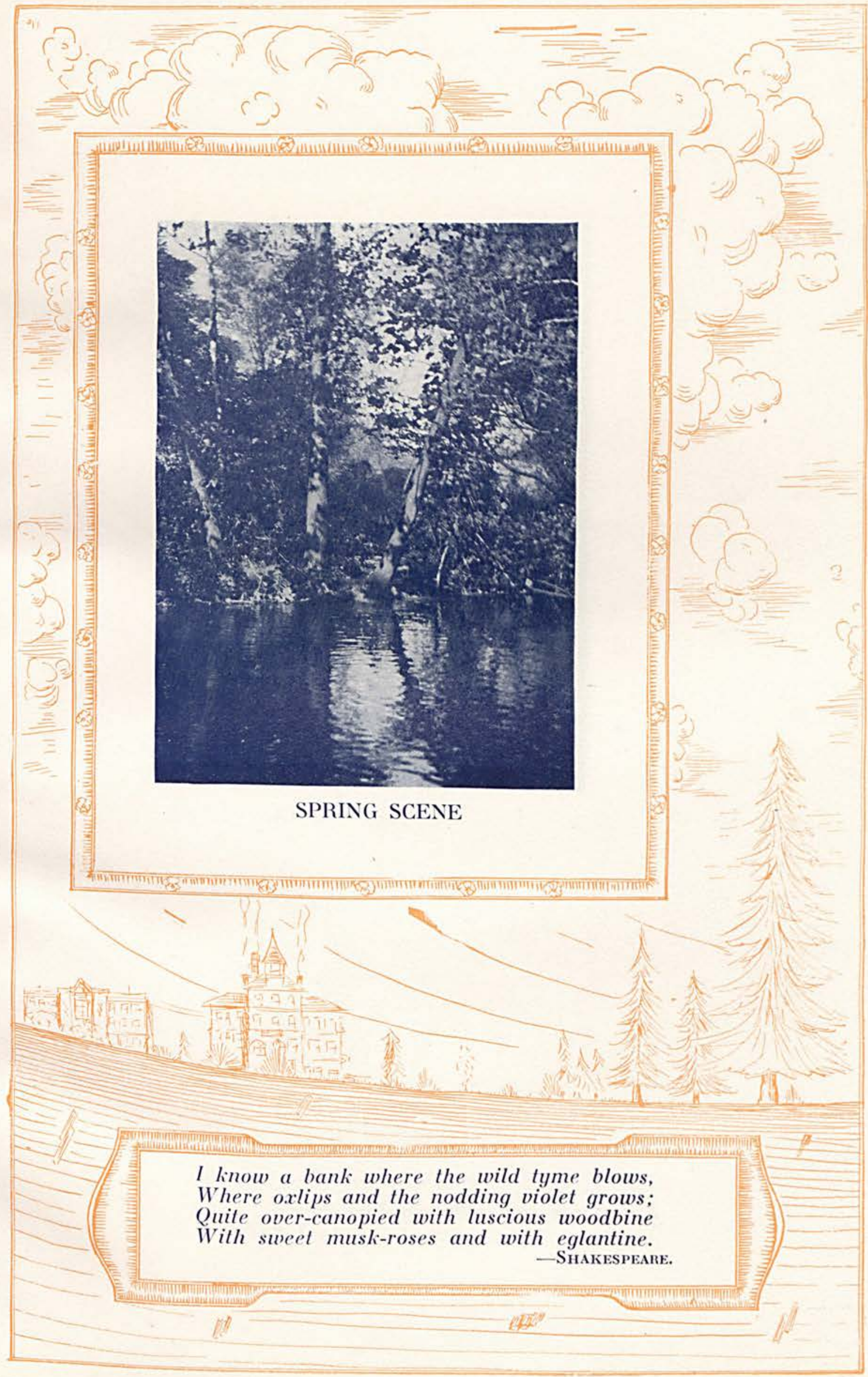




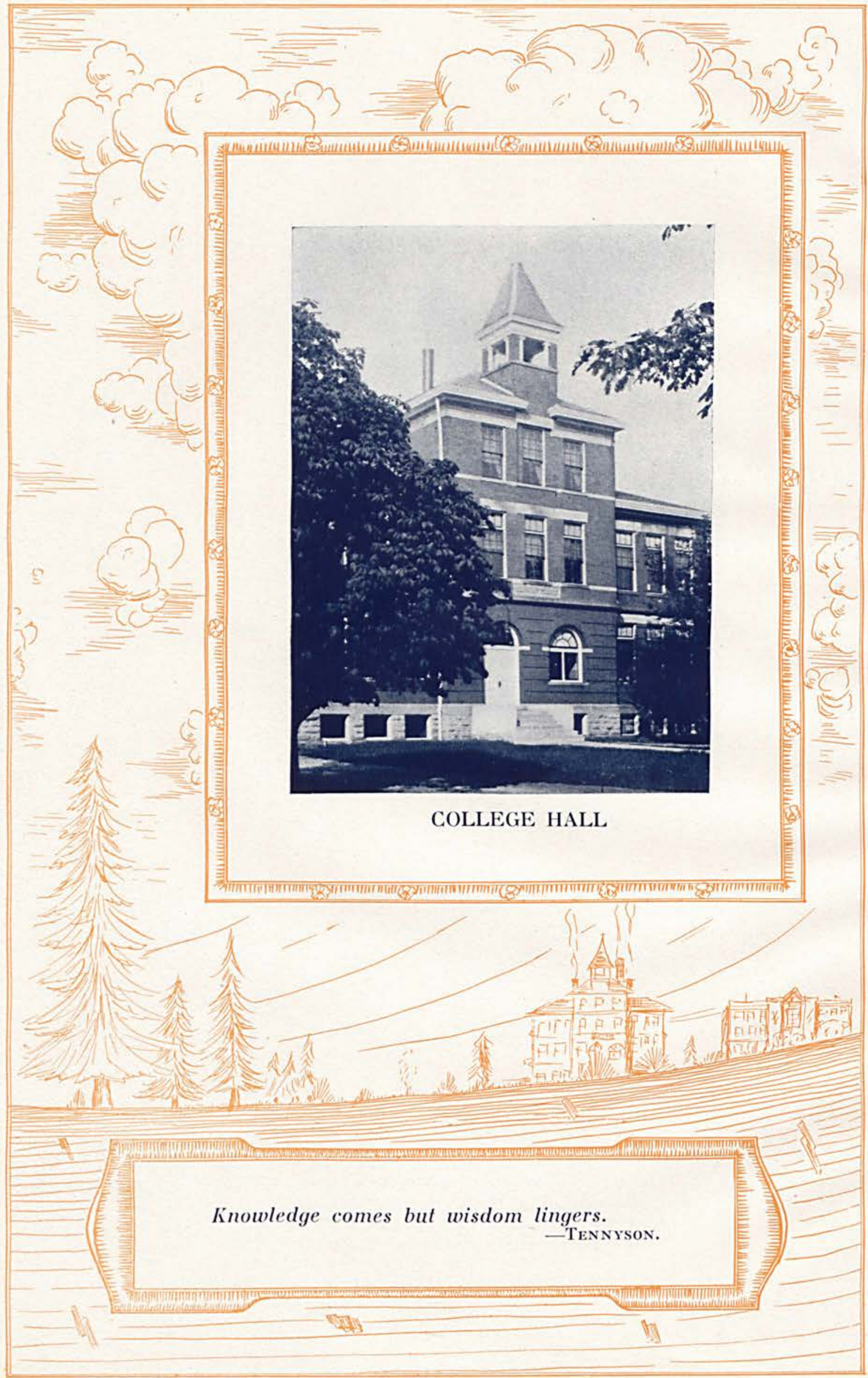




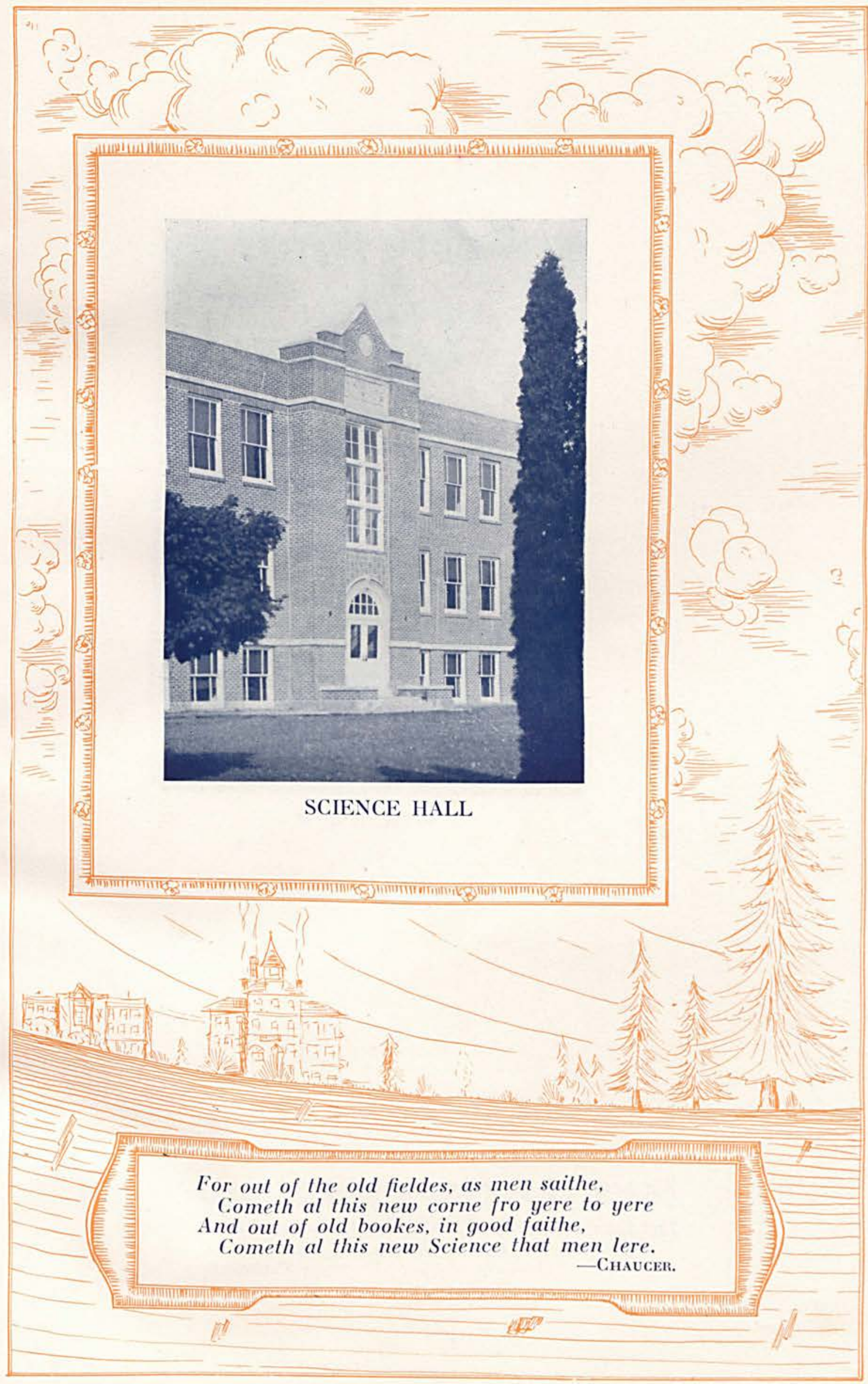




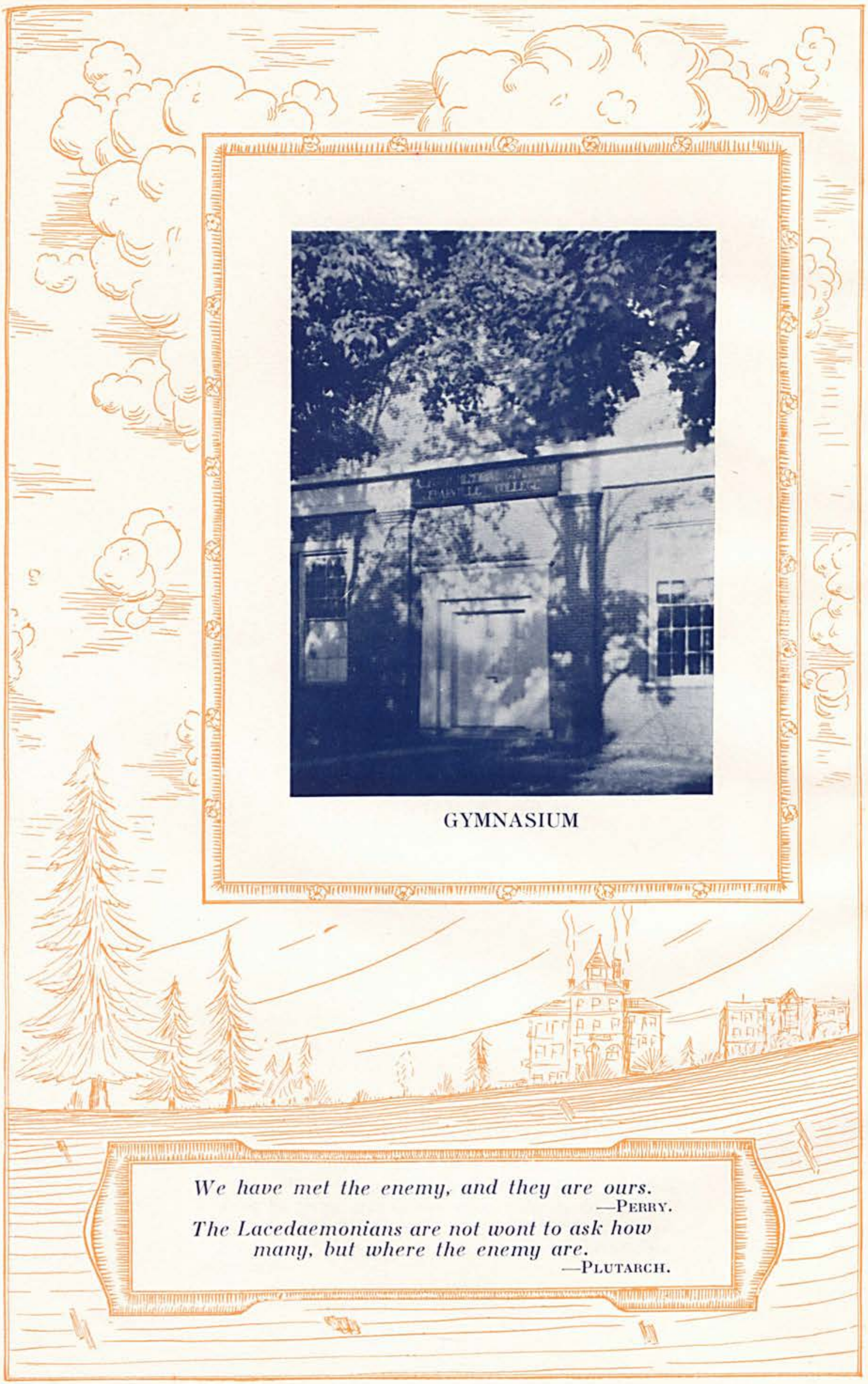




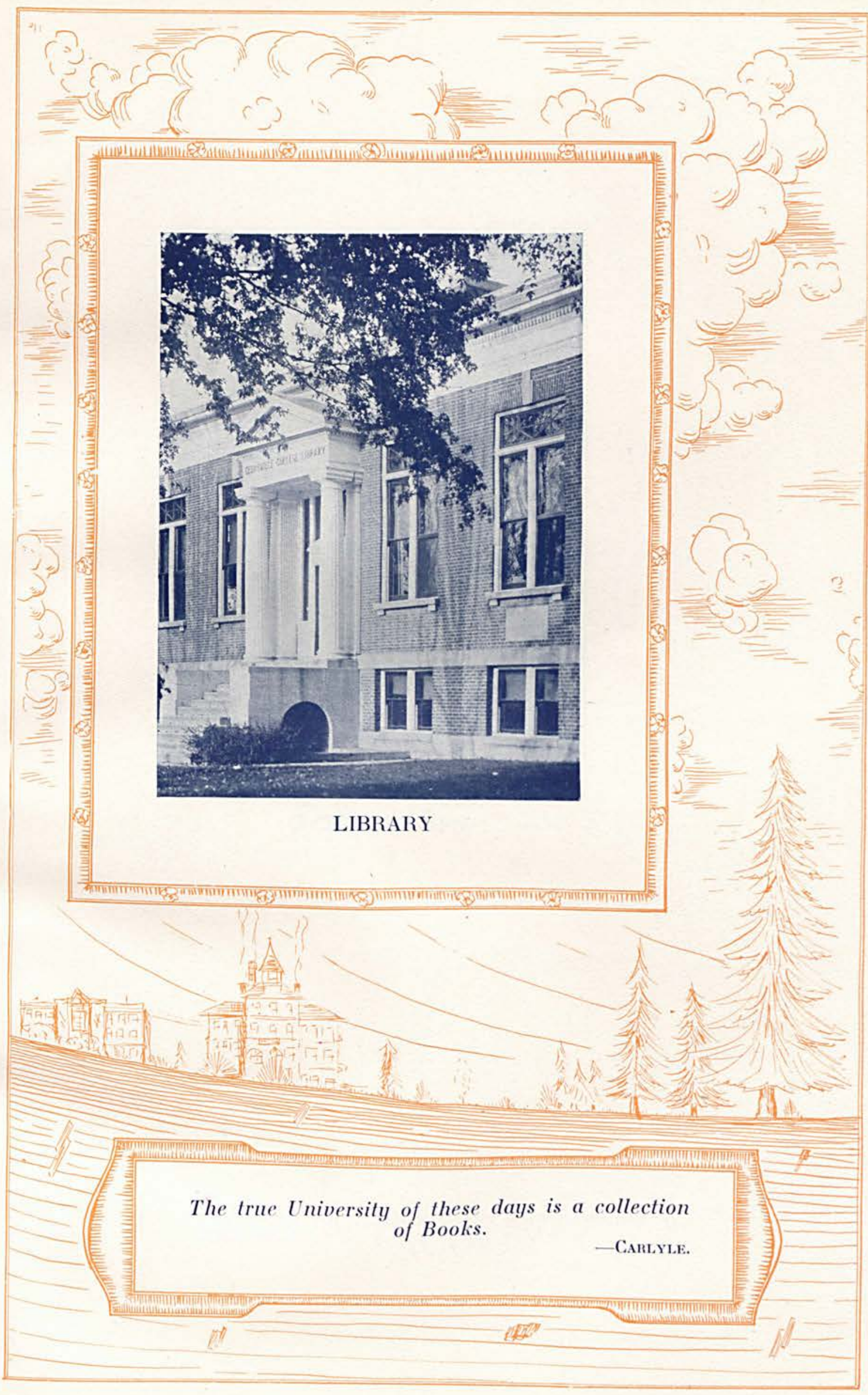




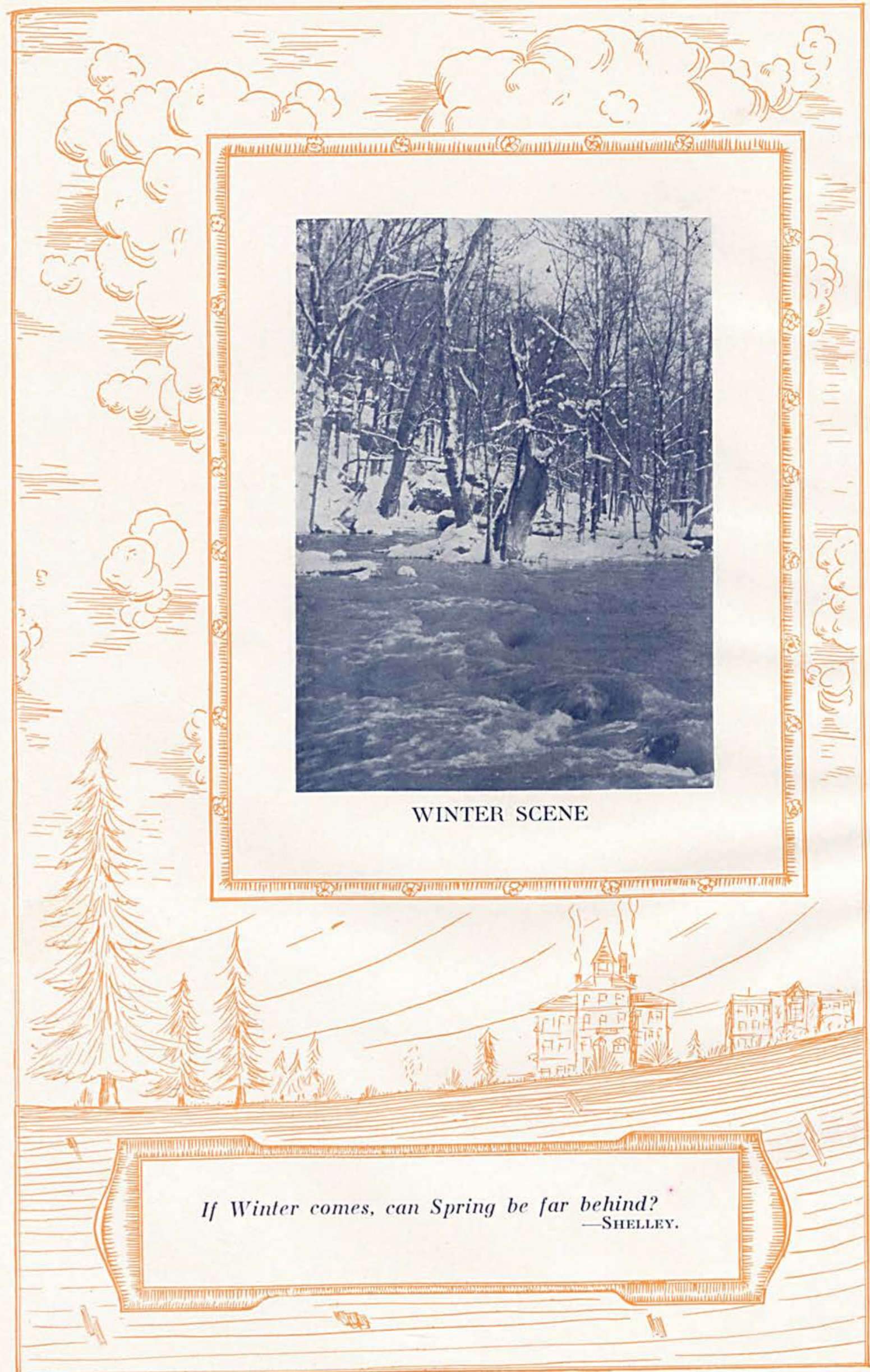




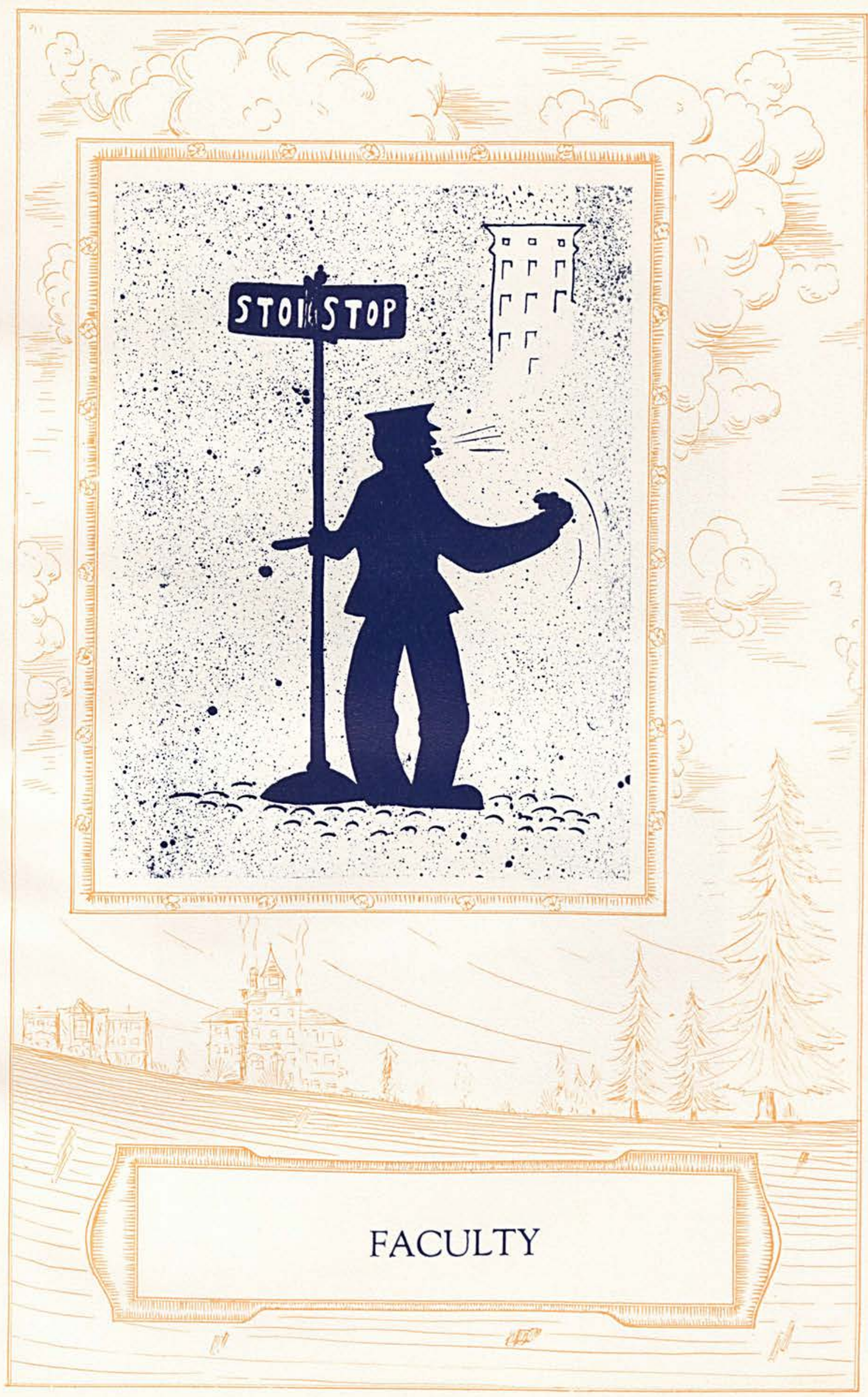





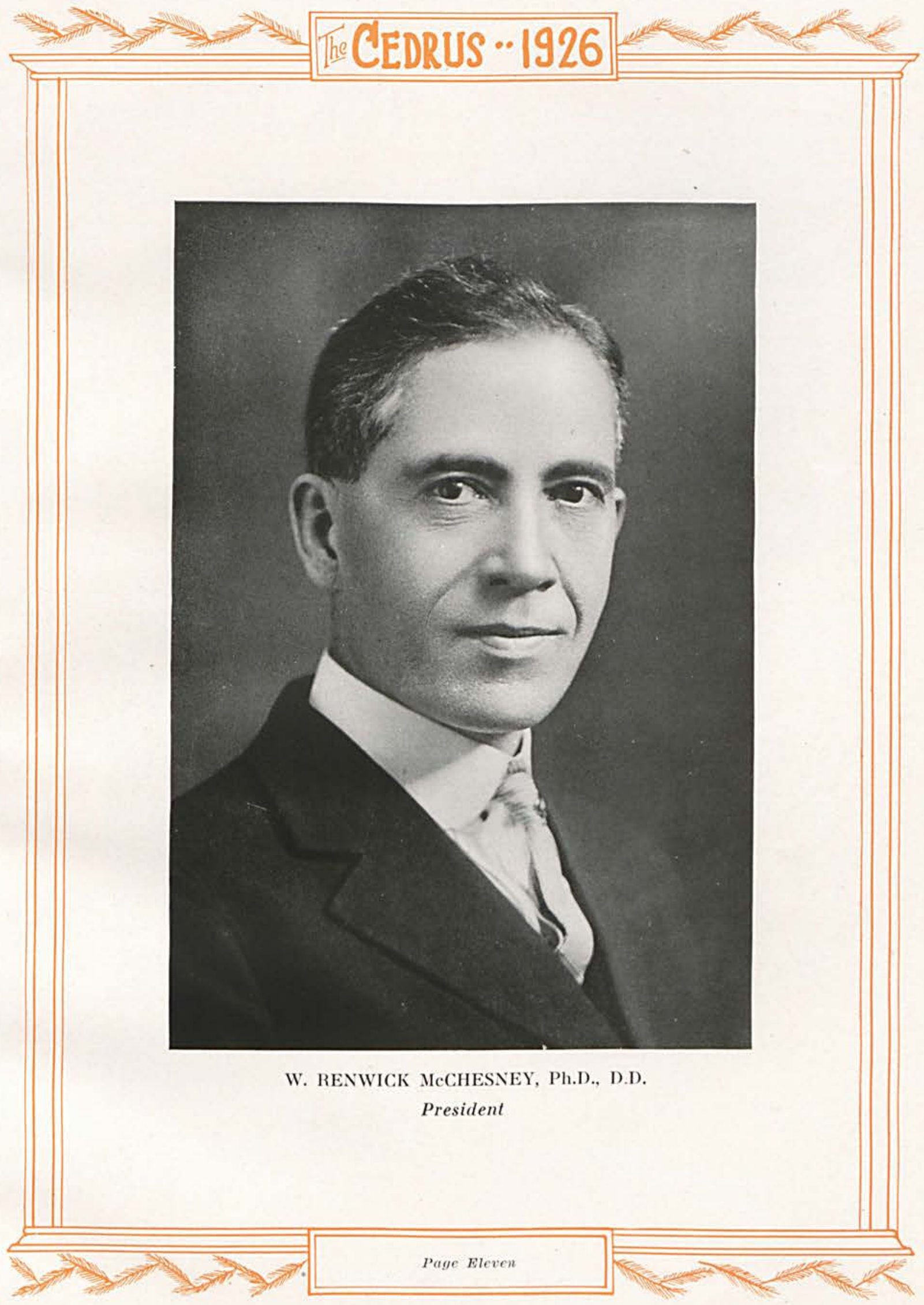




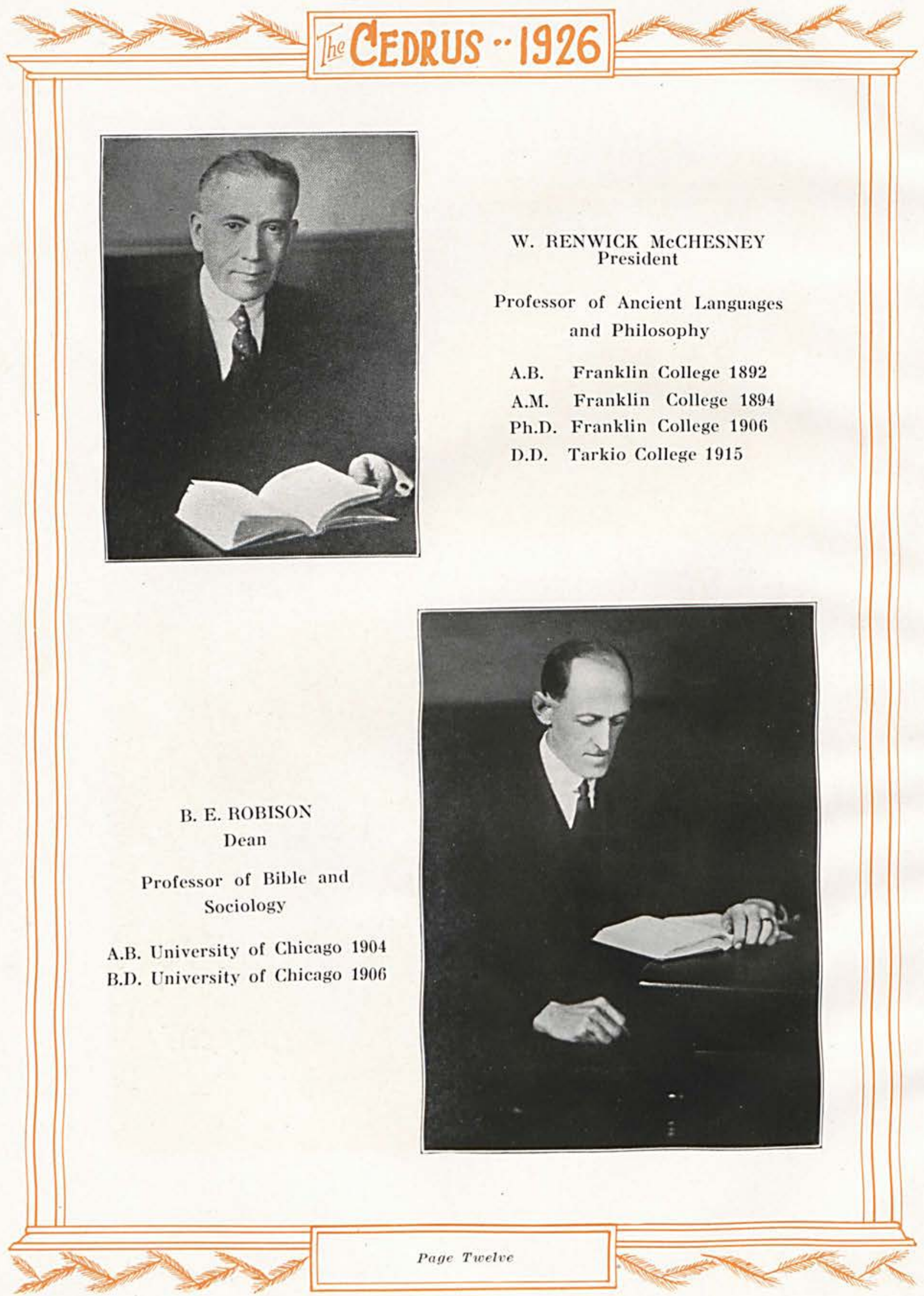




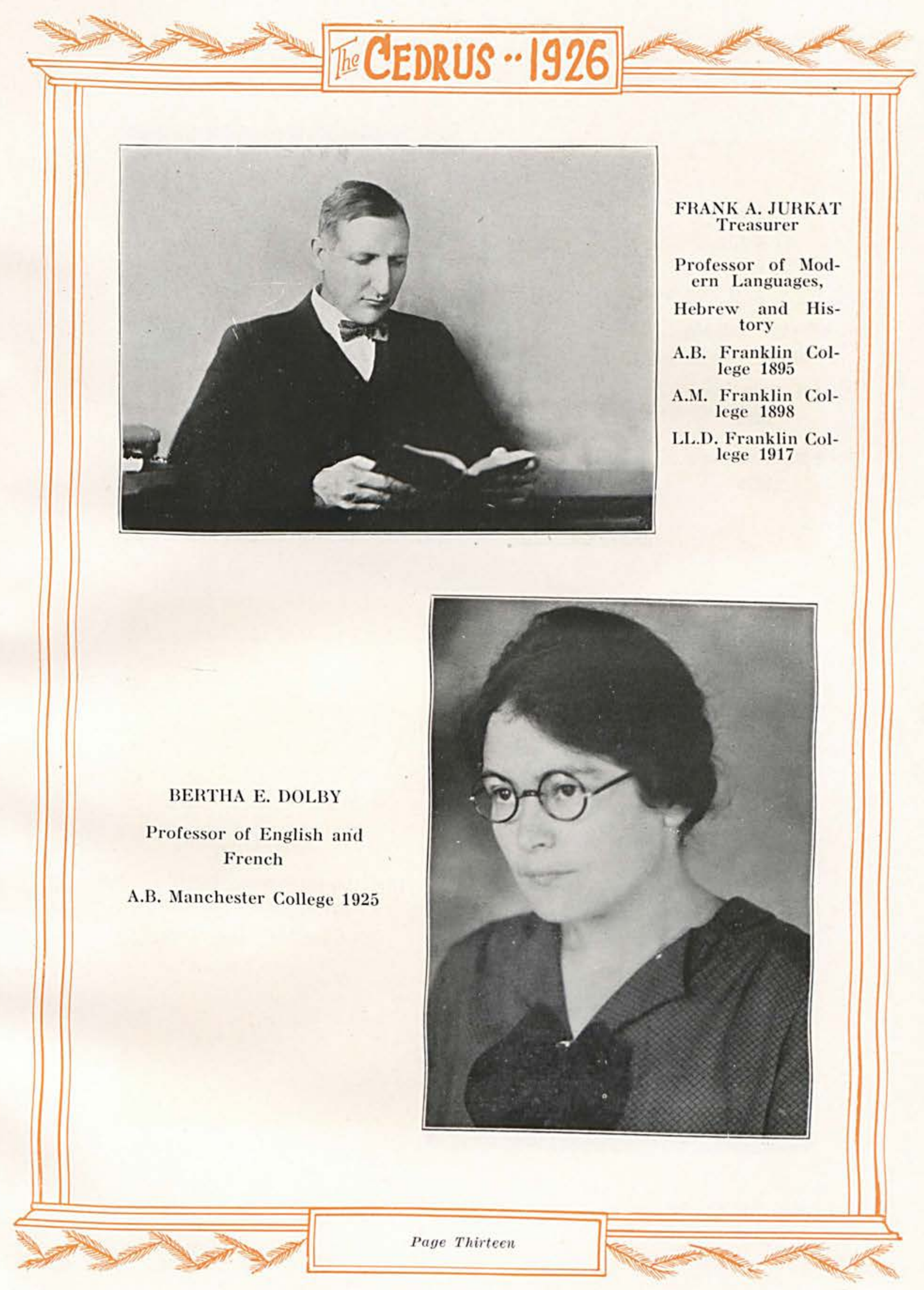




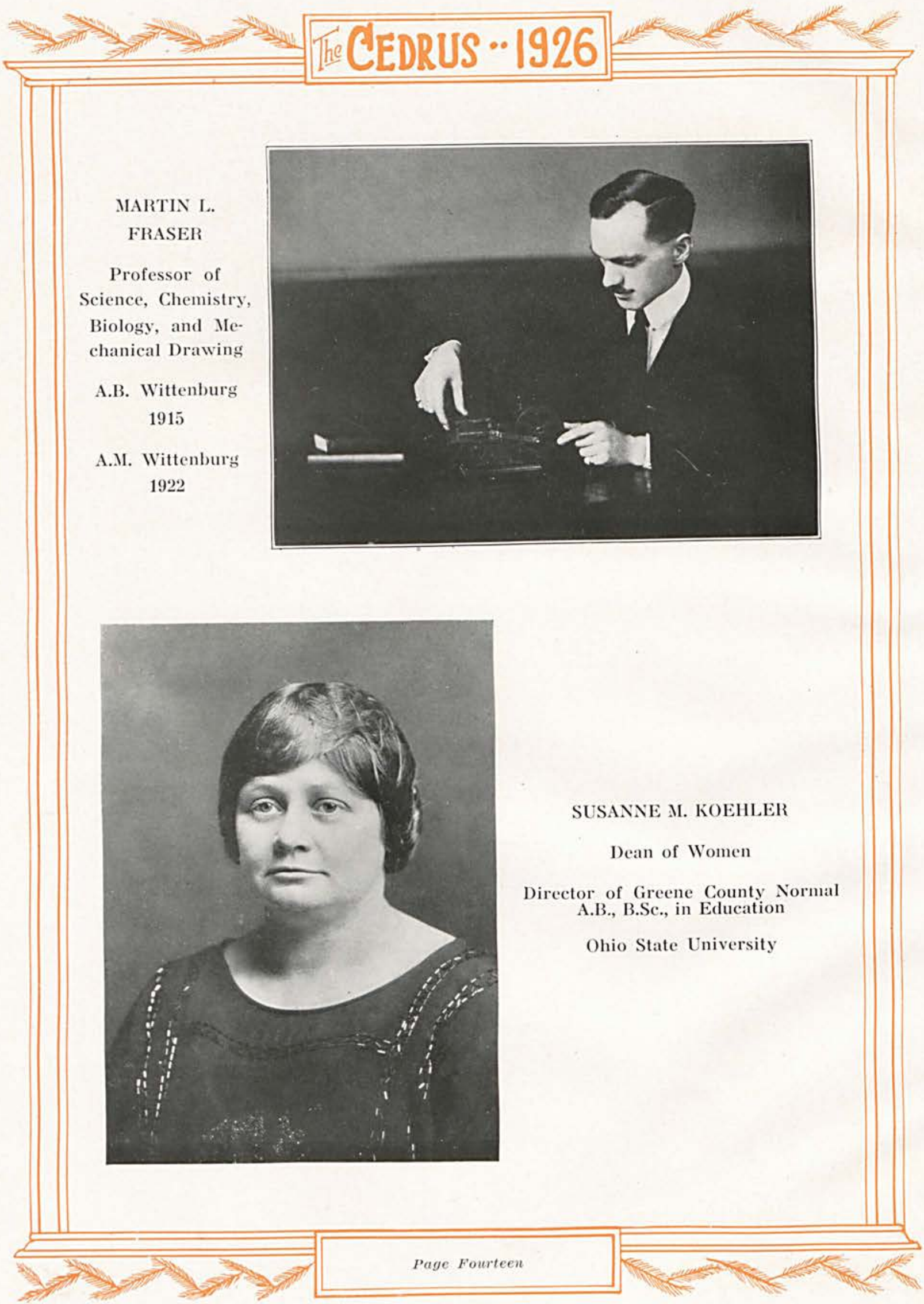




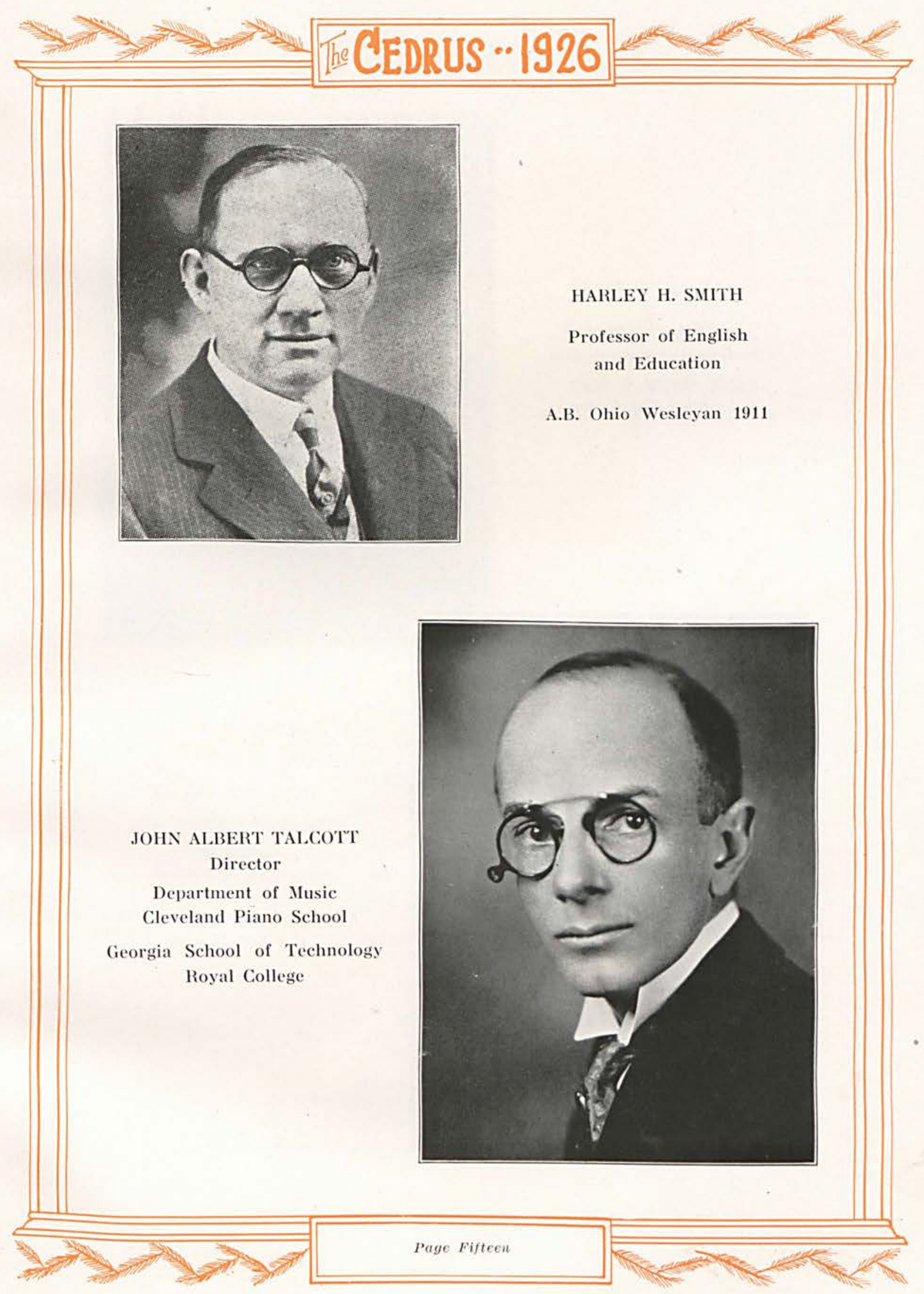




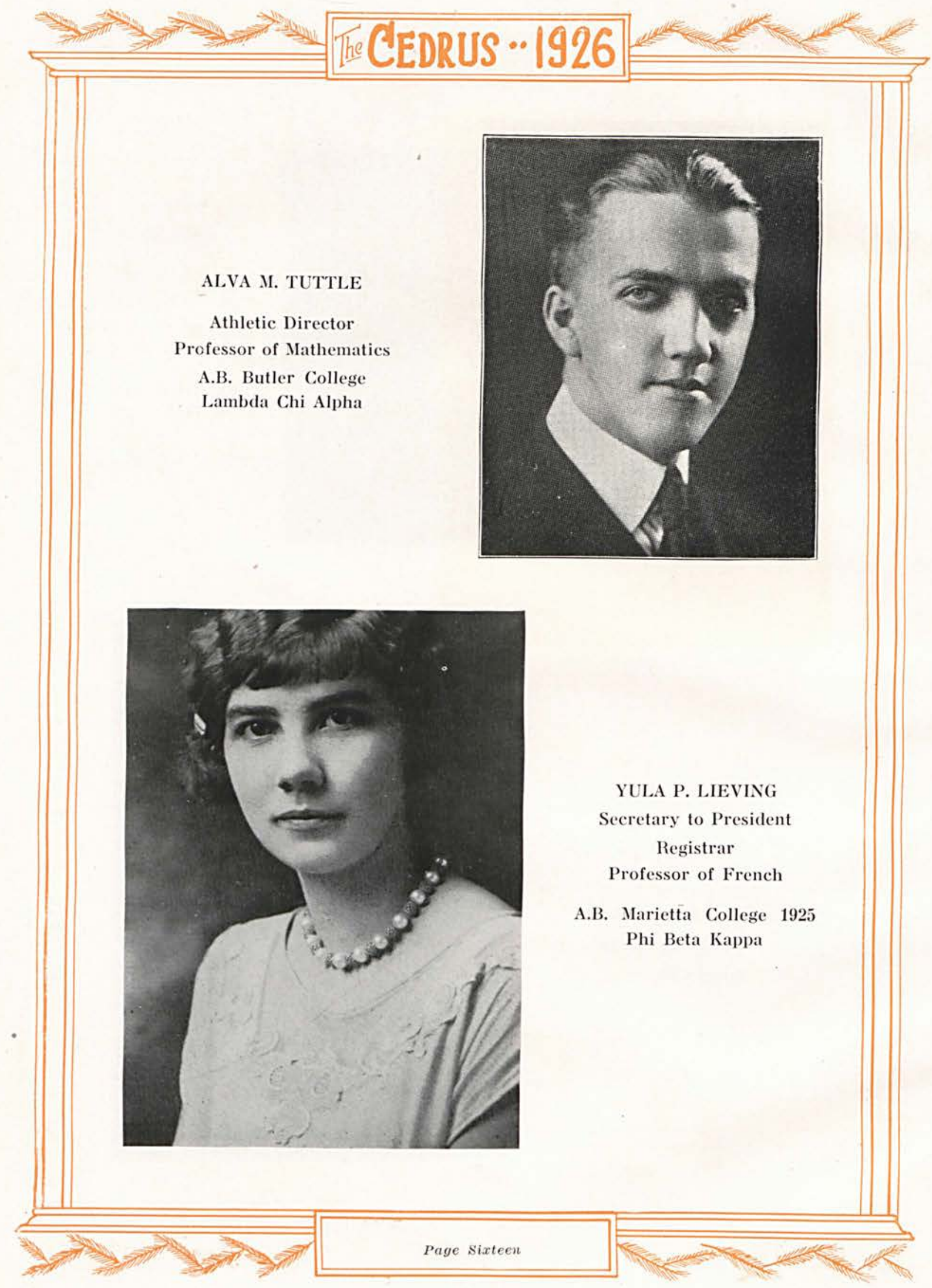




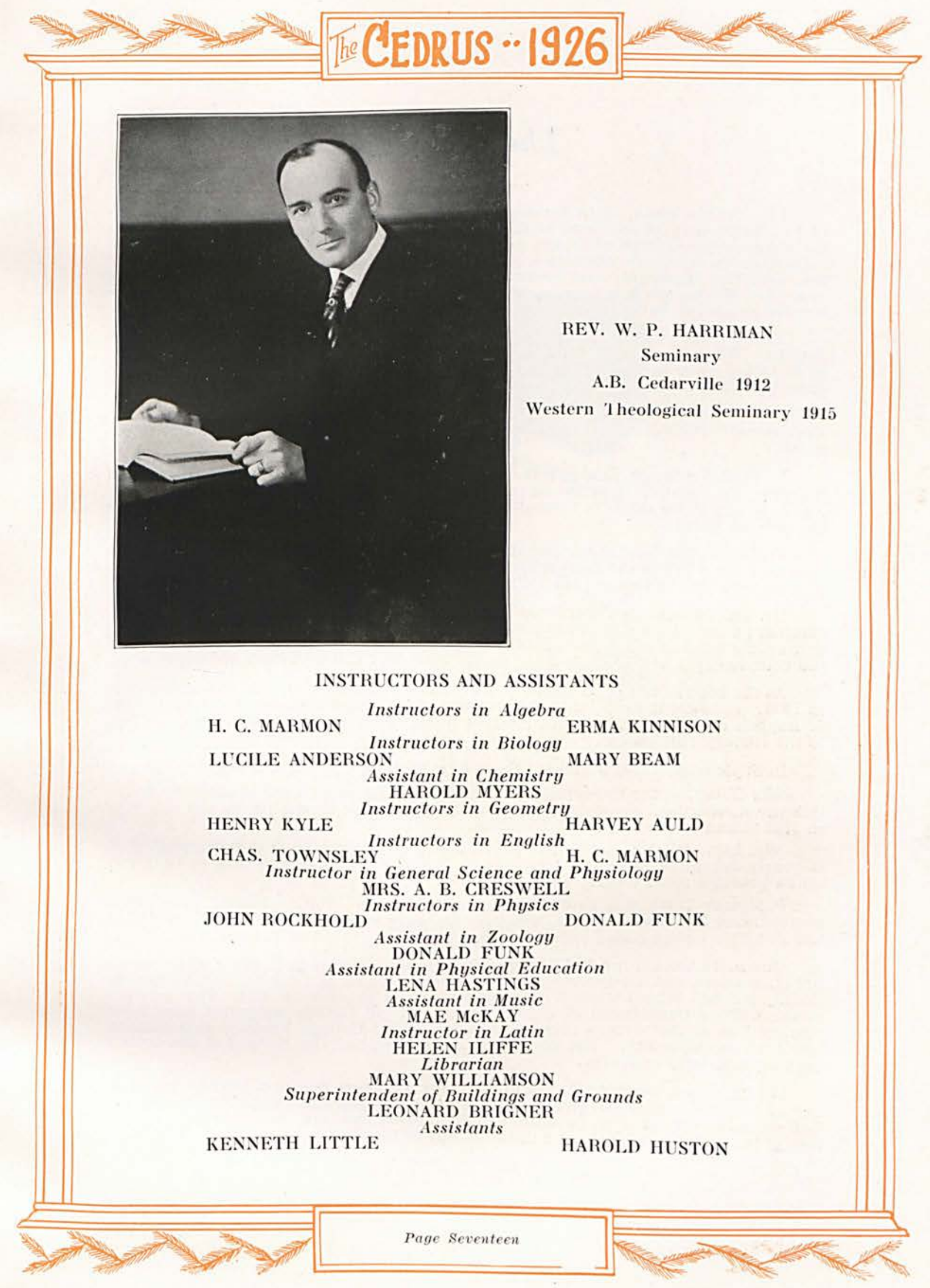




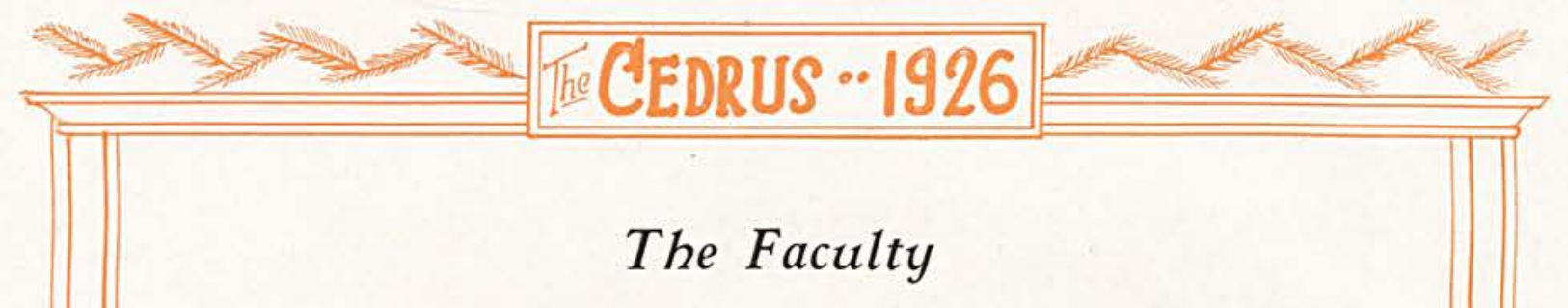

The Cedrus again, as in former years has the privilege of putting the name of Dr. McChesney at the head of the Faculty list. Under his efficient leadership the status of the College continues to become stronger. All on the campus, as well as former students, are conscious of the honor of having for President one who has held that honorable and onerous position for eleven years. For thirty-two years Dr. McChesney has been a member of the Faculty. May his years of active service reach the half-century mark!

Another one of our Faculty has seen all the classes, from 1897 to 1926 , come and go. When the members of the Class of 1930 graduate, we expect Dr. Jurkat to be in his office to receive the new Freshmen and also their money, and so help them take their first steps toward securing their college degrees.

From 1896 to 1921 many came as professors to add their contributions to the development of Cedarville College, but none of them are with us to-day except in spirit.

In 1922 Professor Fraser joined the Faculty as head of the Department of Science. In vacation days he serves the College as a fisher of men (Freshmen). As Chairman of the Athletic Committee he has done much to bring our athletics to the present status.

Professor Robison also came in 1922. In September of that year he took charge of the work in the Departments of Bible and Social Science. The following year he was chosen Dean of the College.

Dr. Talcott became Director of the Department of Music in 1923. Under his efficient guidance the department has advanced until it commands the admiration and commendation of ali friends of the College. He has given to the College and the community a higher regard for music than was known before he came to us.

As the head of the Department of Education Professor Smith became one of us in 1924. In order to keep him busy we have given him a share in the Departments of English and History. He has made it possible for us to add two new courses to the History curriculum.

In September, 1925, we added three new members to our numbers.

Miss Dolby, in the Department of French and English, is doing much to maintain the standards of these departments. She has made it possible to add a course in Journalism to the English curriculum.

Miss Lieving, as Registrar and Secretary to the President, is doing a work that is yearly becoming more important as the College grows in size and as its reputation becomes more widespread.

Professor Tuttle has guided the activities of our athletic teams. Creditable performance has been the rule, whether we were victors or victims. Courses in Coaching have been added to the department.

One more worker we feel honored in numbering with us because of her sympathy, counsel, and co-operation. Miss Koehler came as Director of the Greene County Normal School when it was located on our campus in 1923. Her services to the college Department of Education, and in all College activities have been rendered as if she were a regular member of the College Faculty, and thus in spirit we consider her. The successful achievement of the Normal is due to her untiring scholarly endeavor.

We know not what the future may bring; we know not how greatly the number of professors may be increased; but we trust that the Faculty of Cedarville College may ever, as now, be united in its desires and endeavors for the realization of the high ideals that were in the minds of the founders. B. E. R.

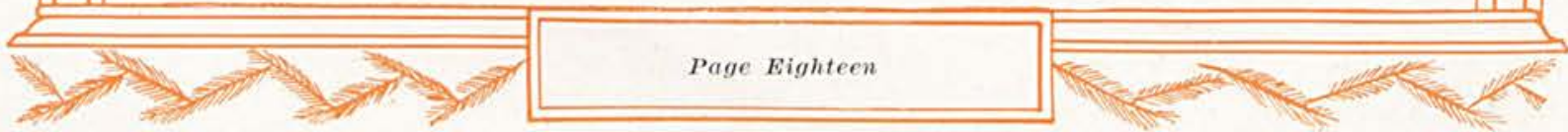




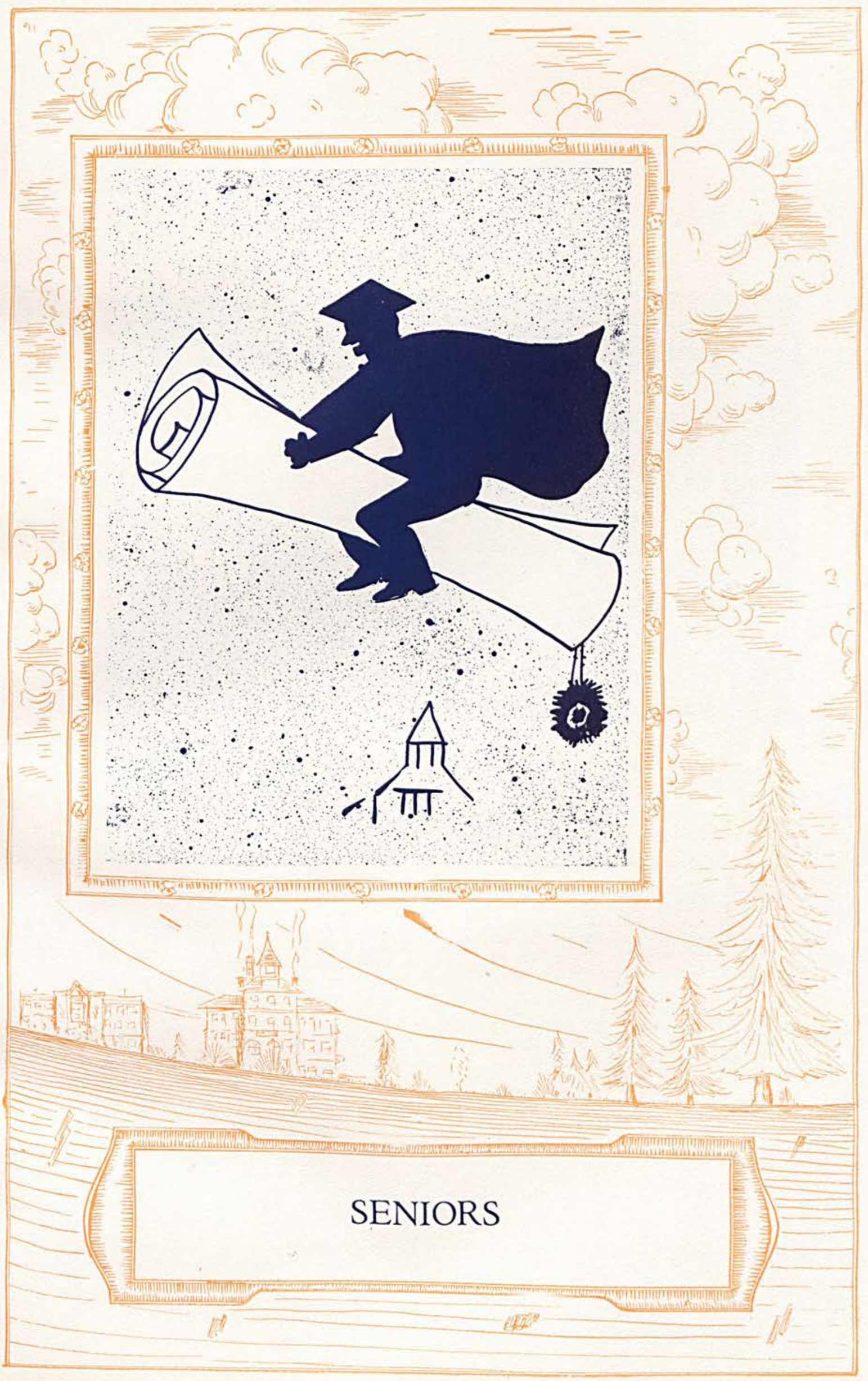




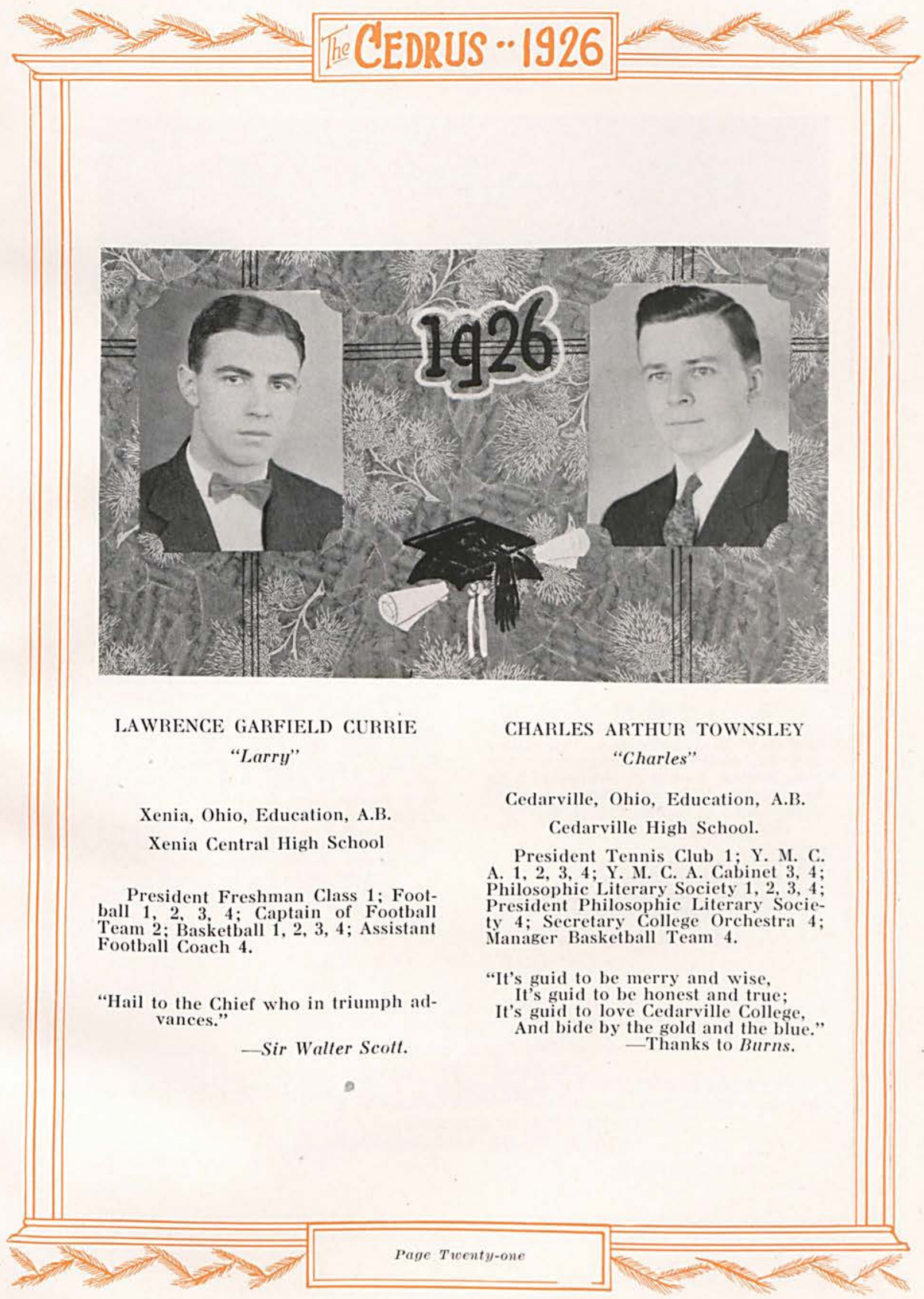




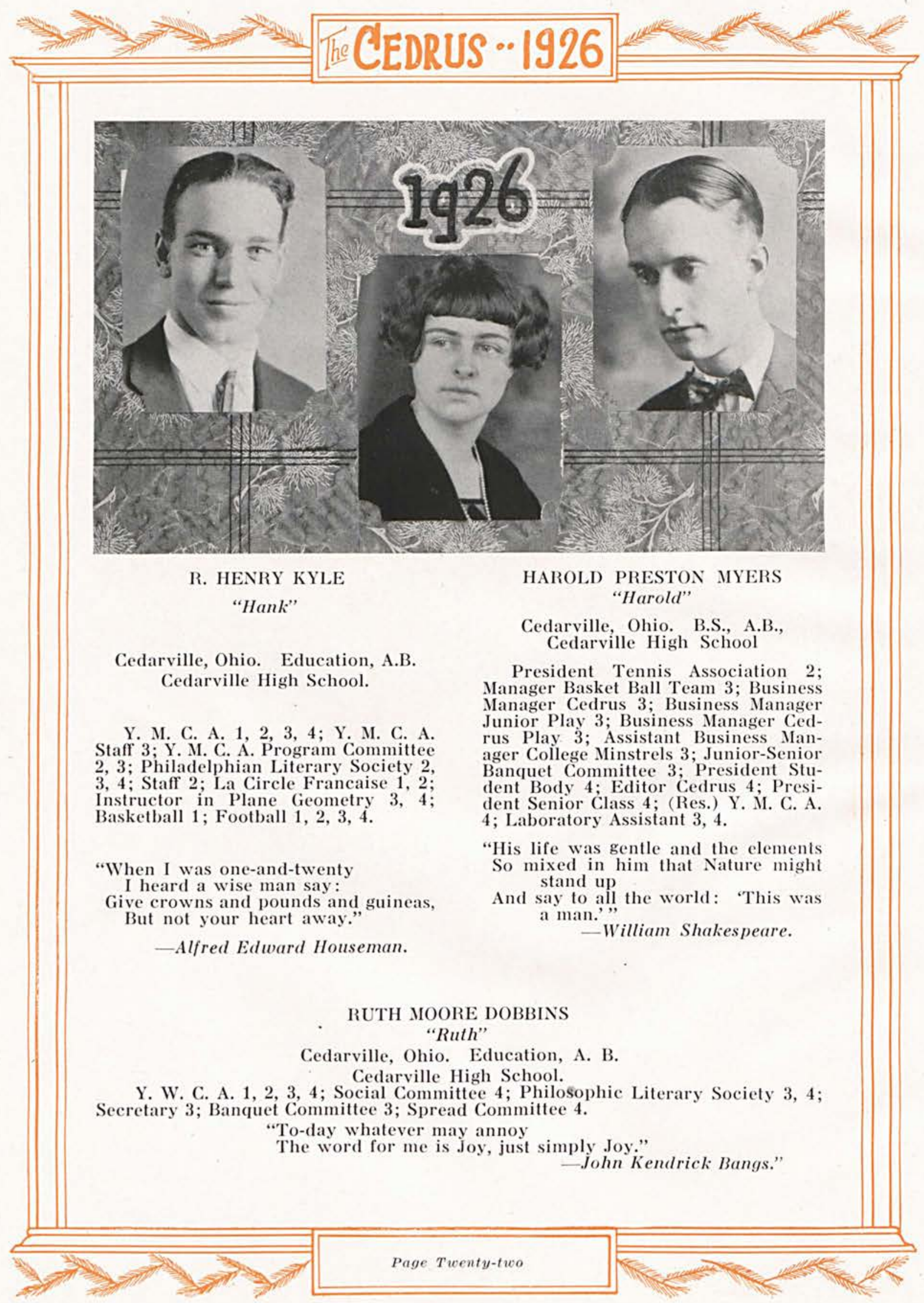




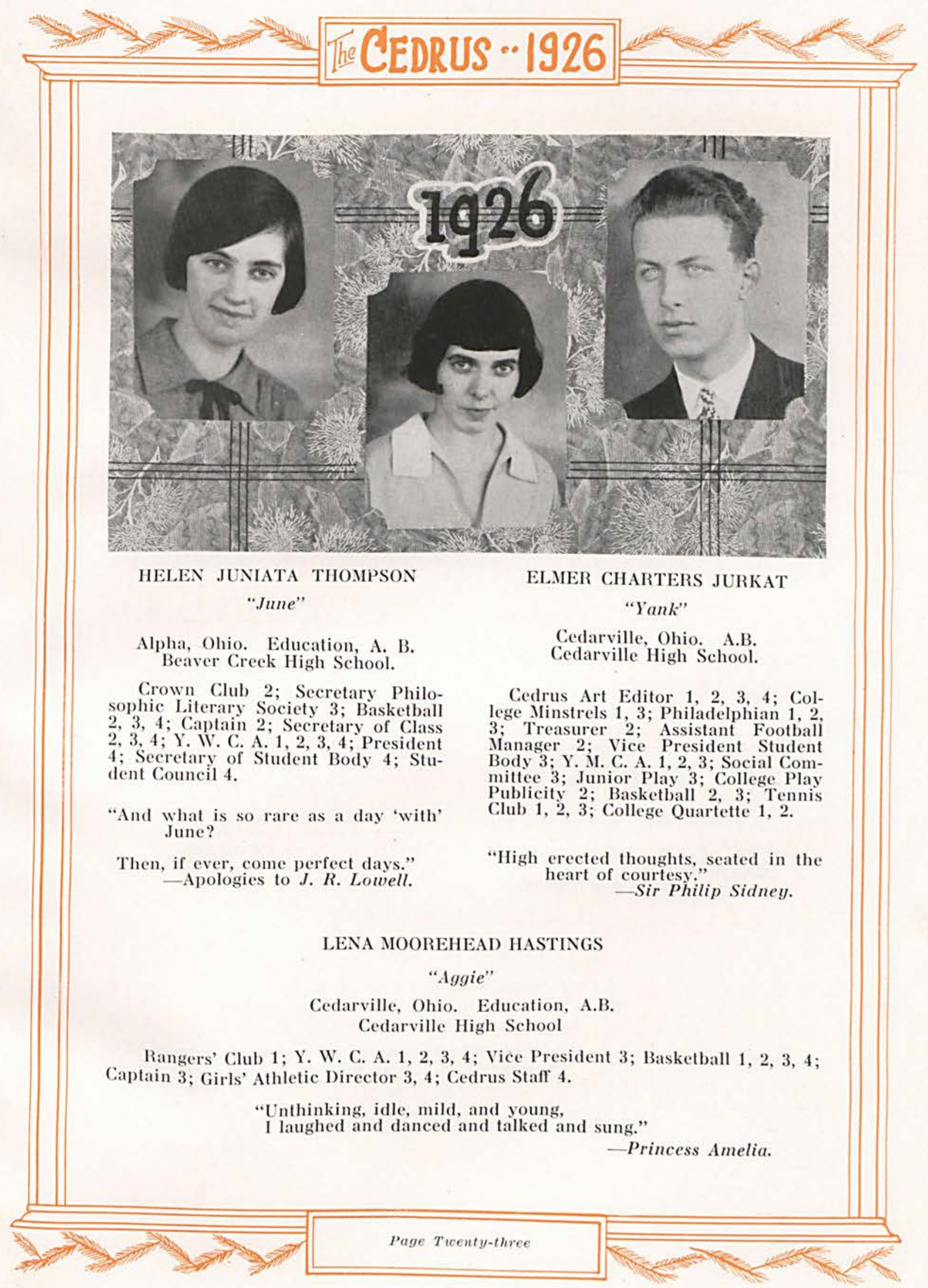




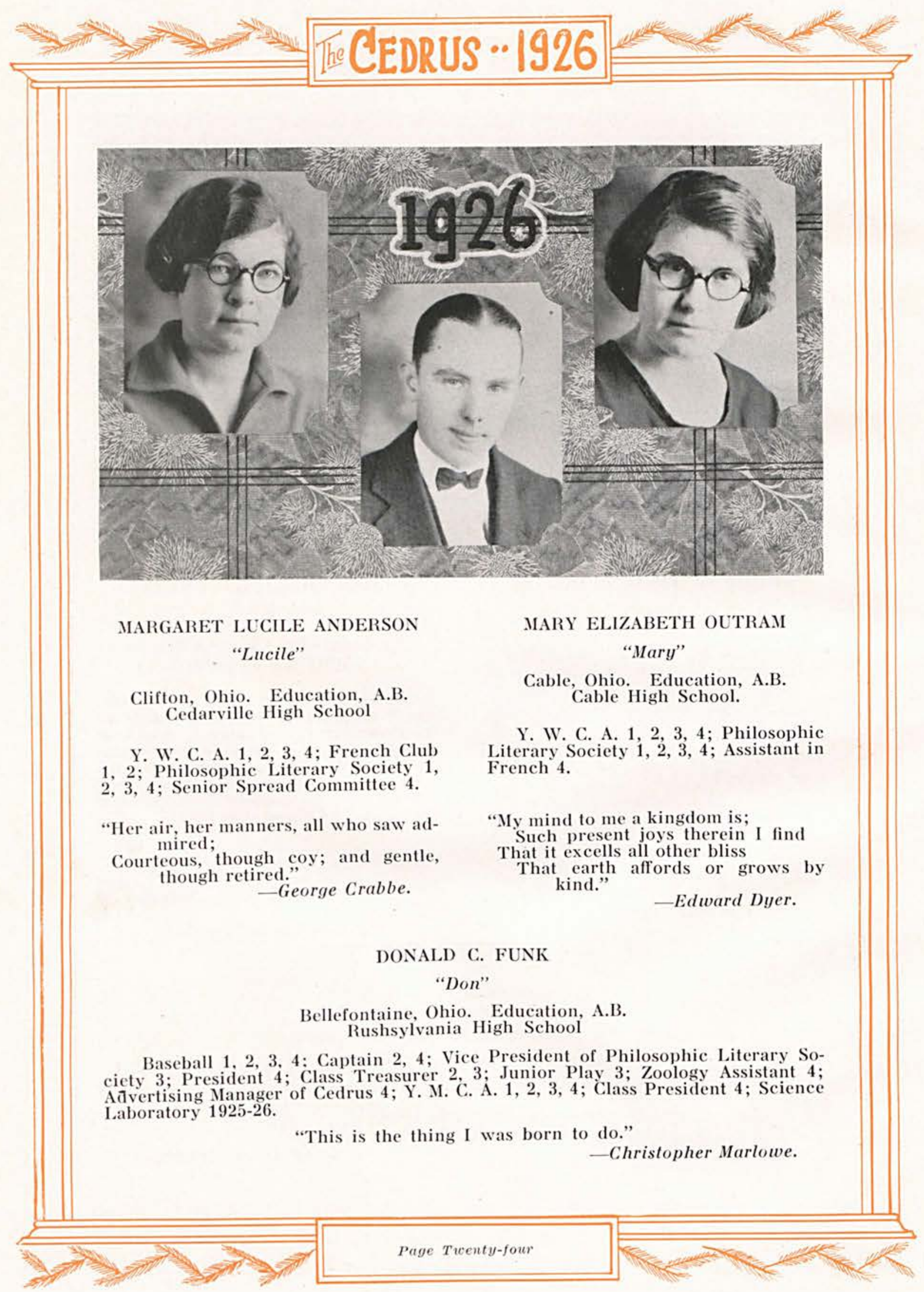




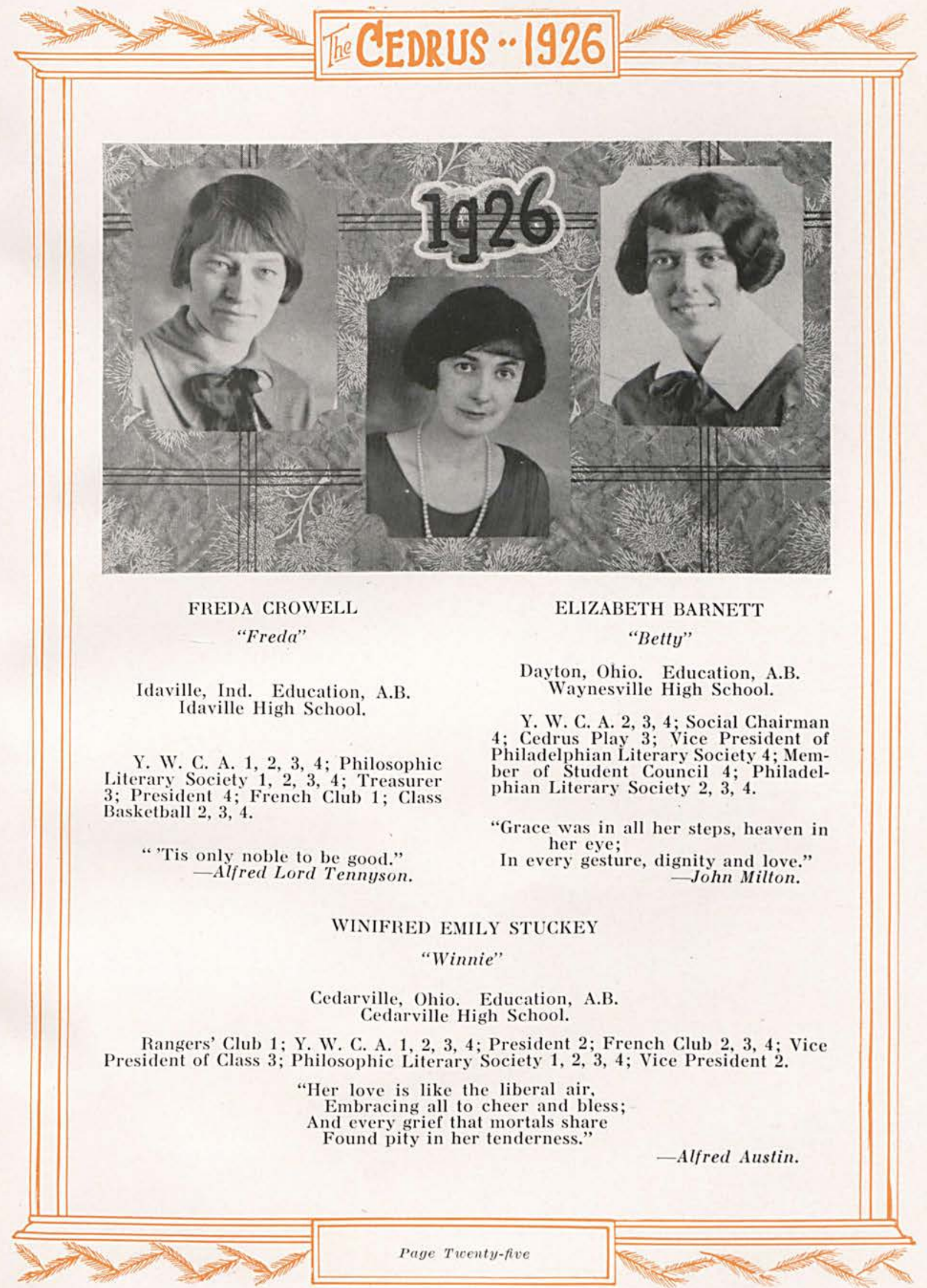




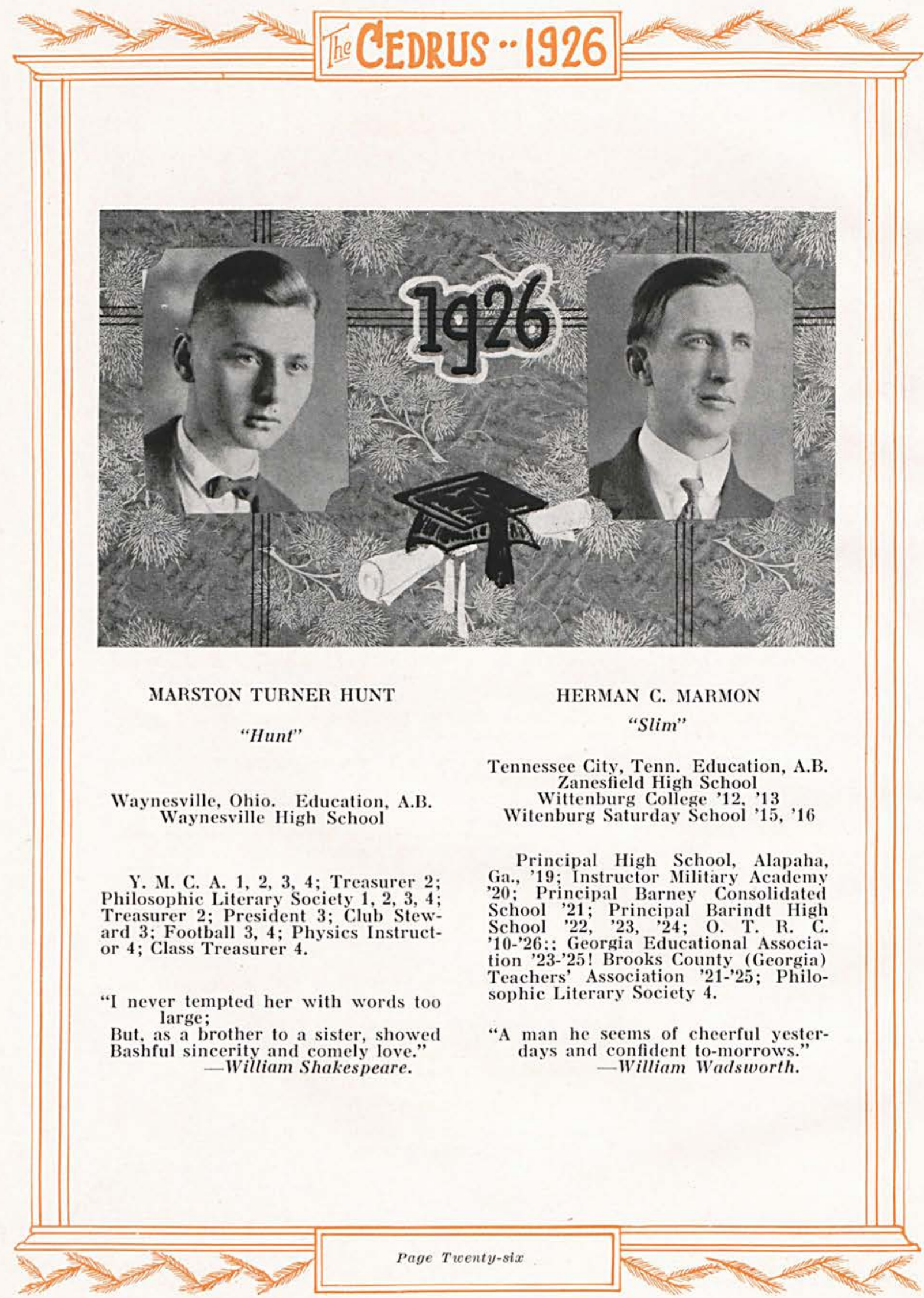




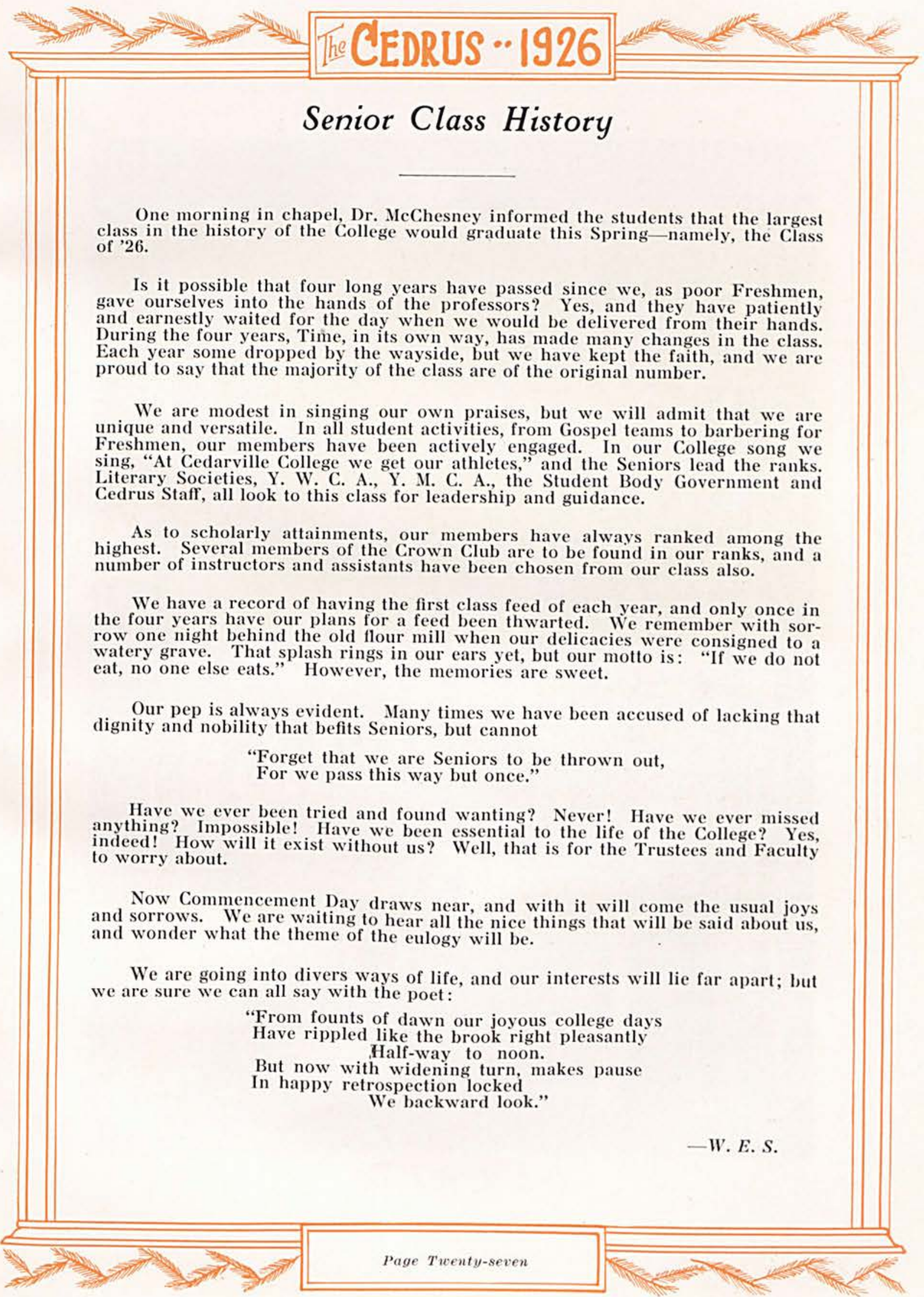




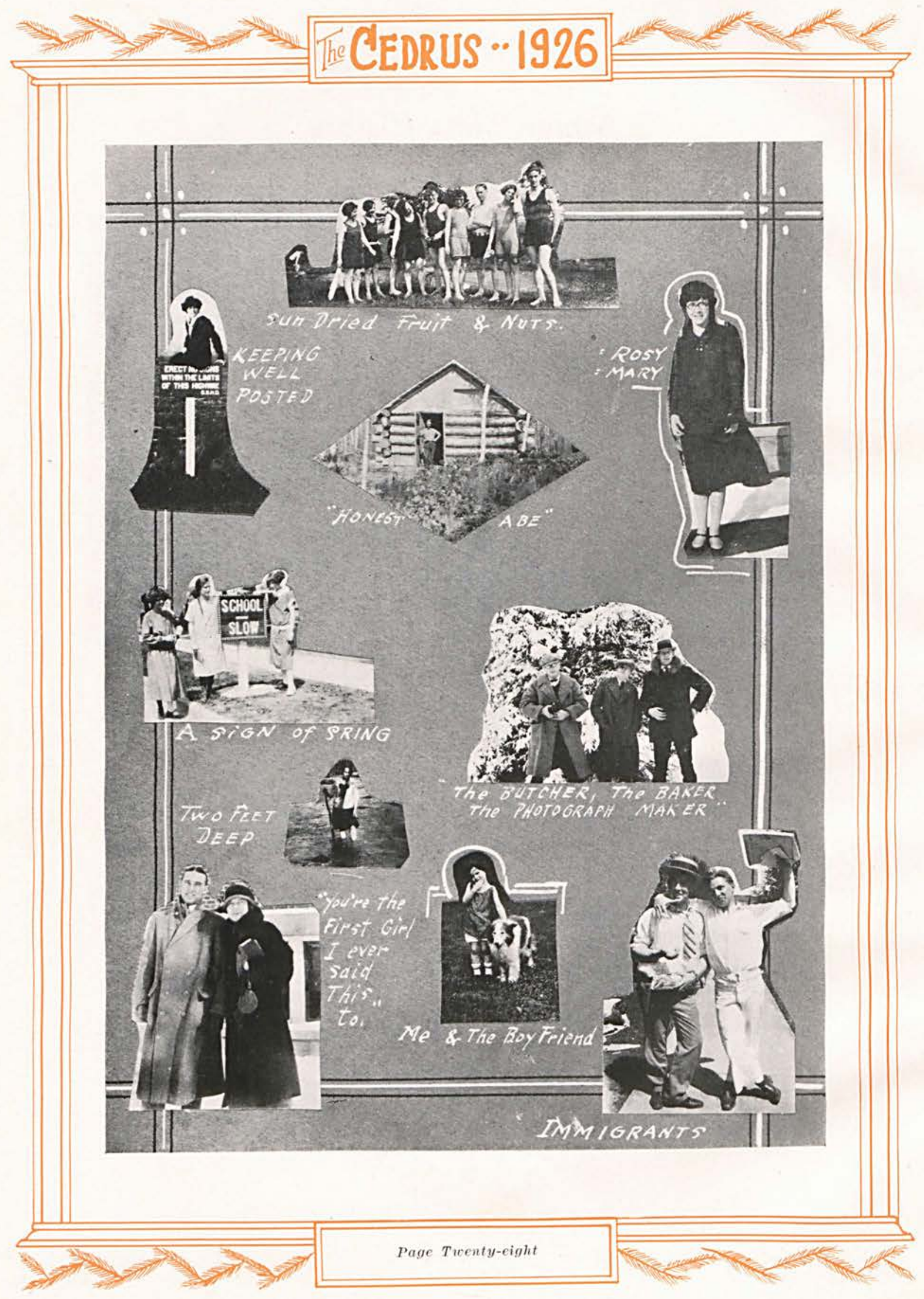




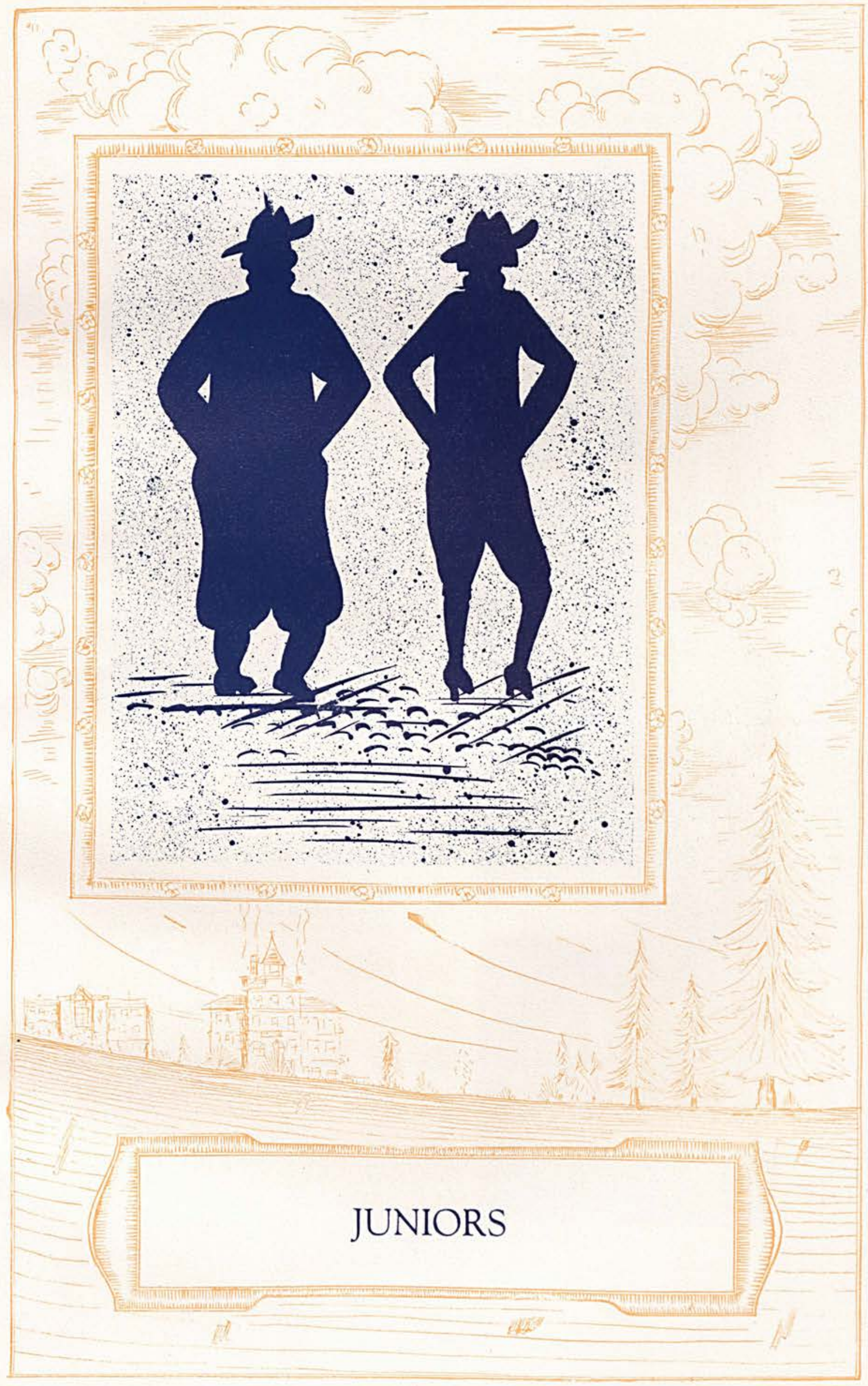





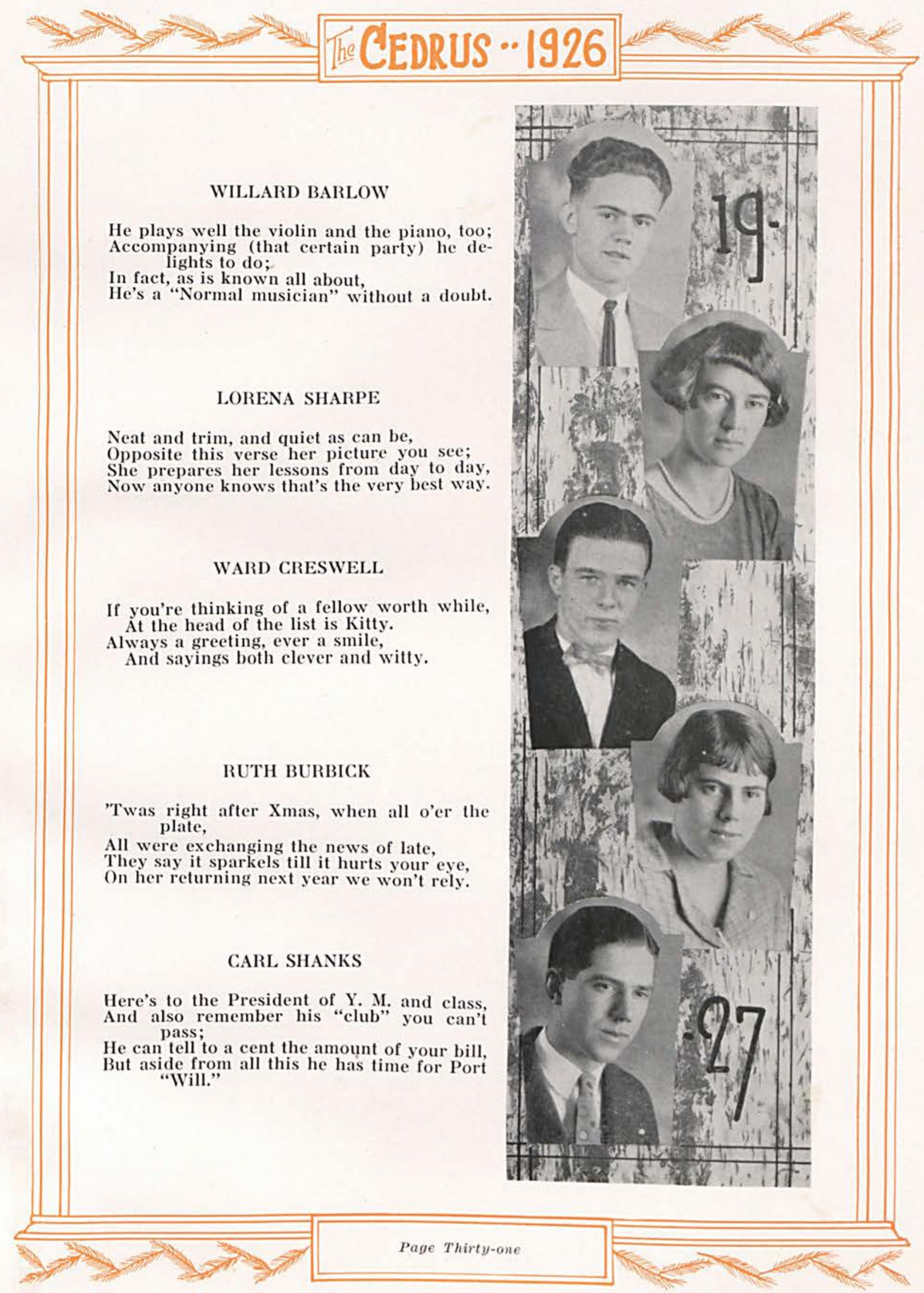




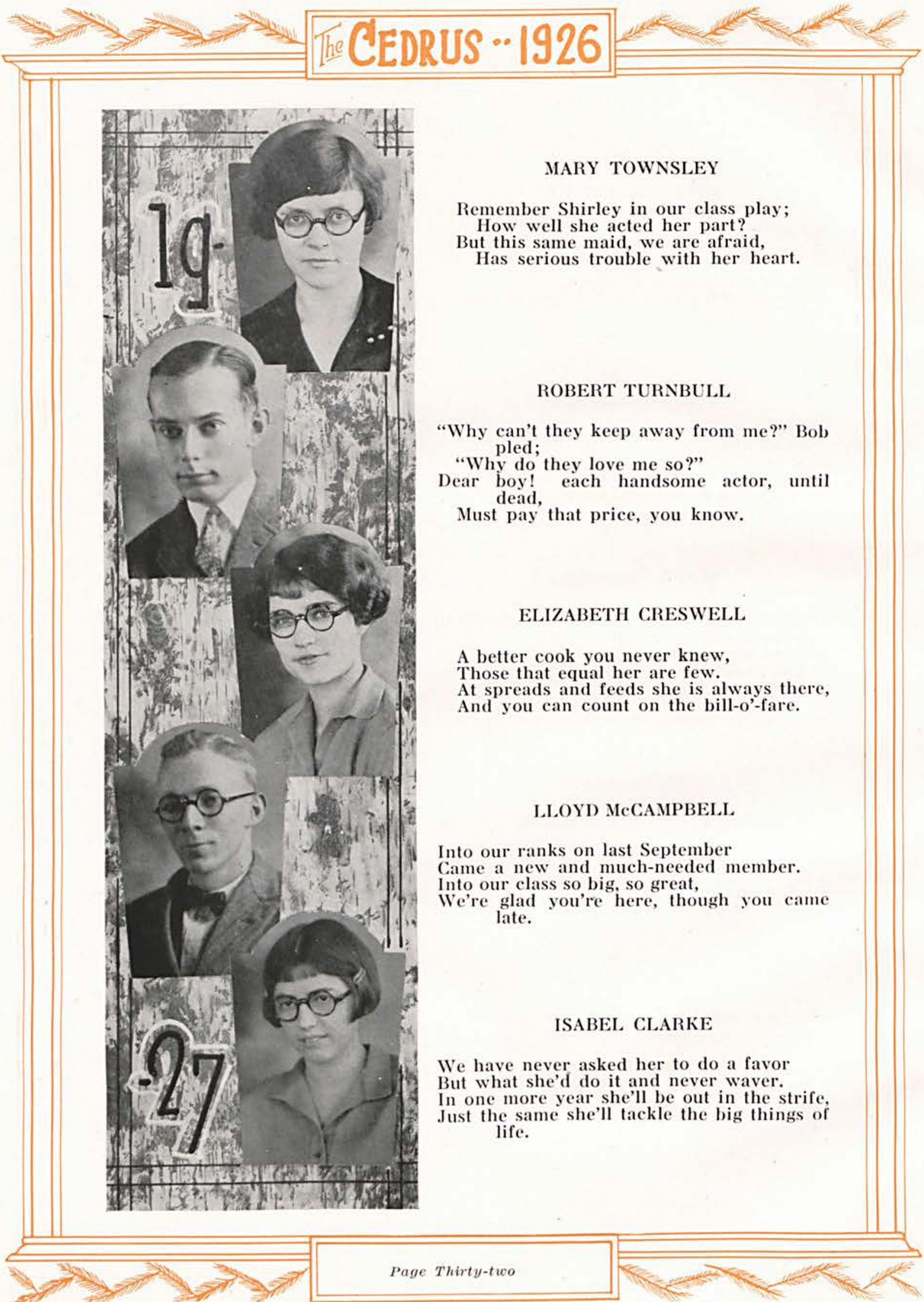




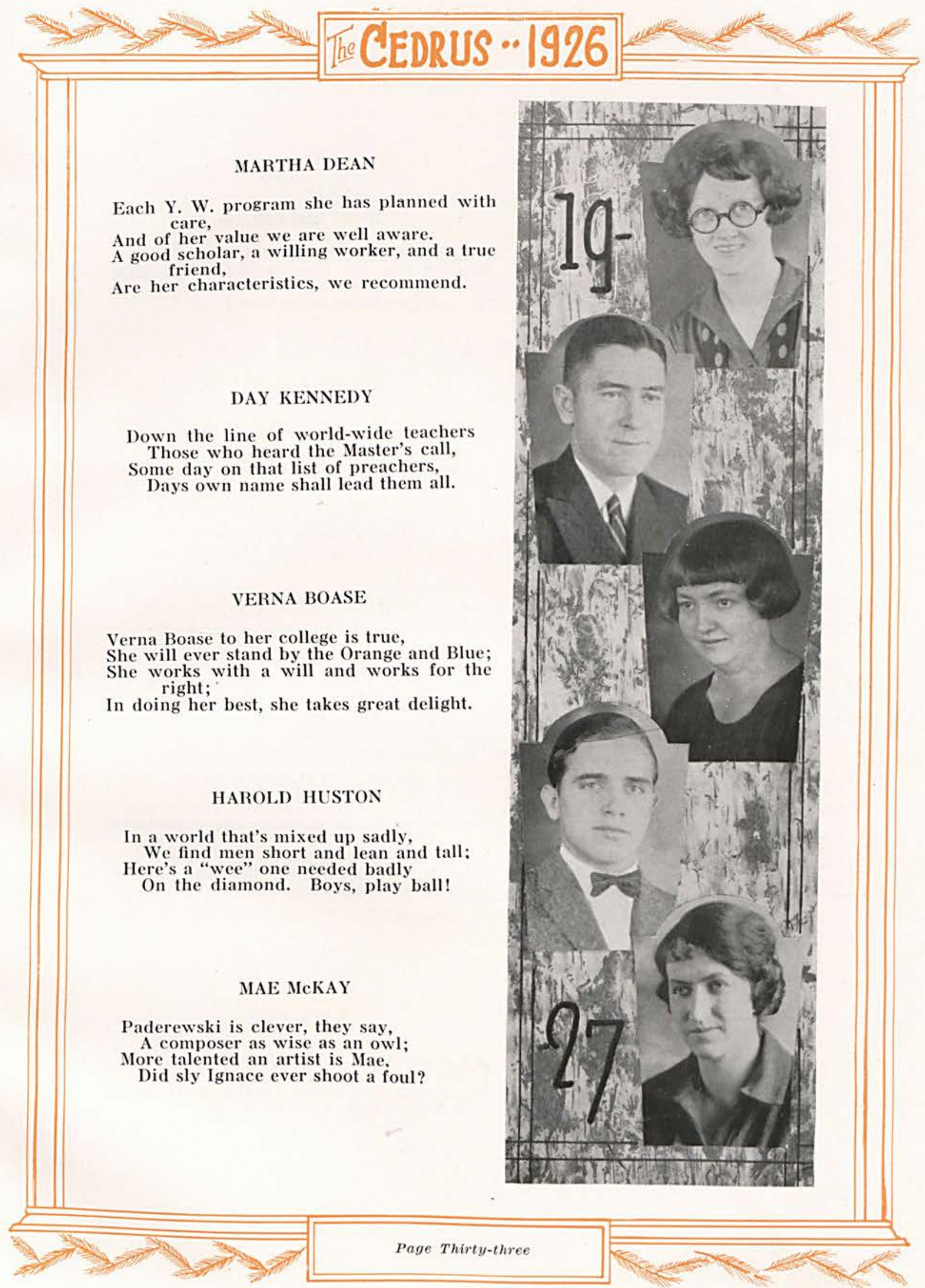




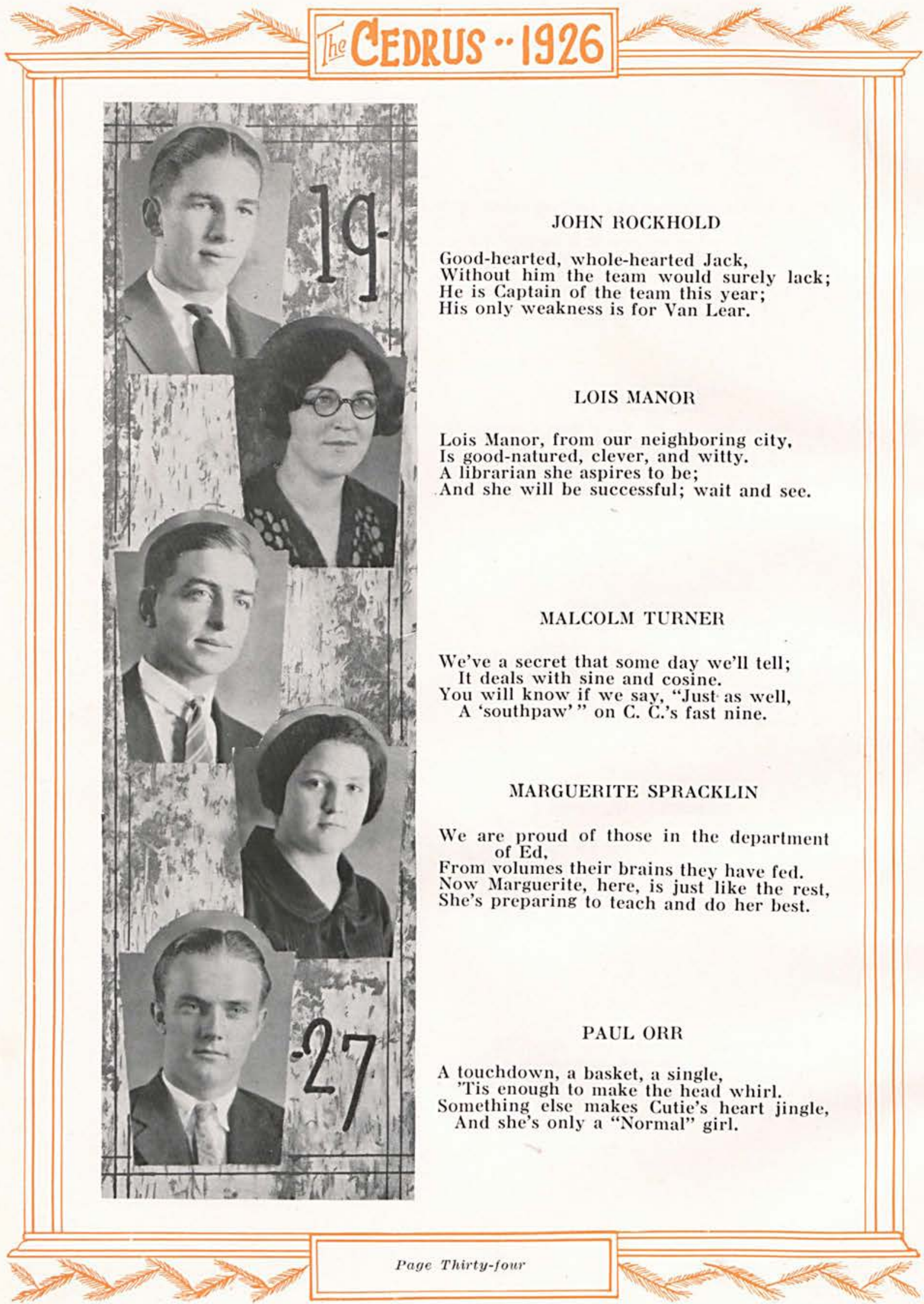




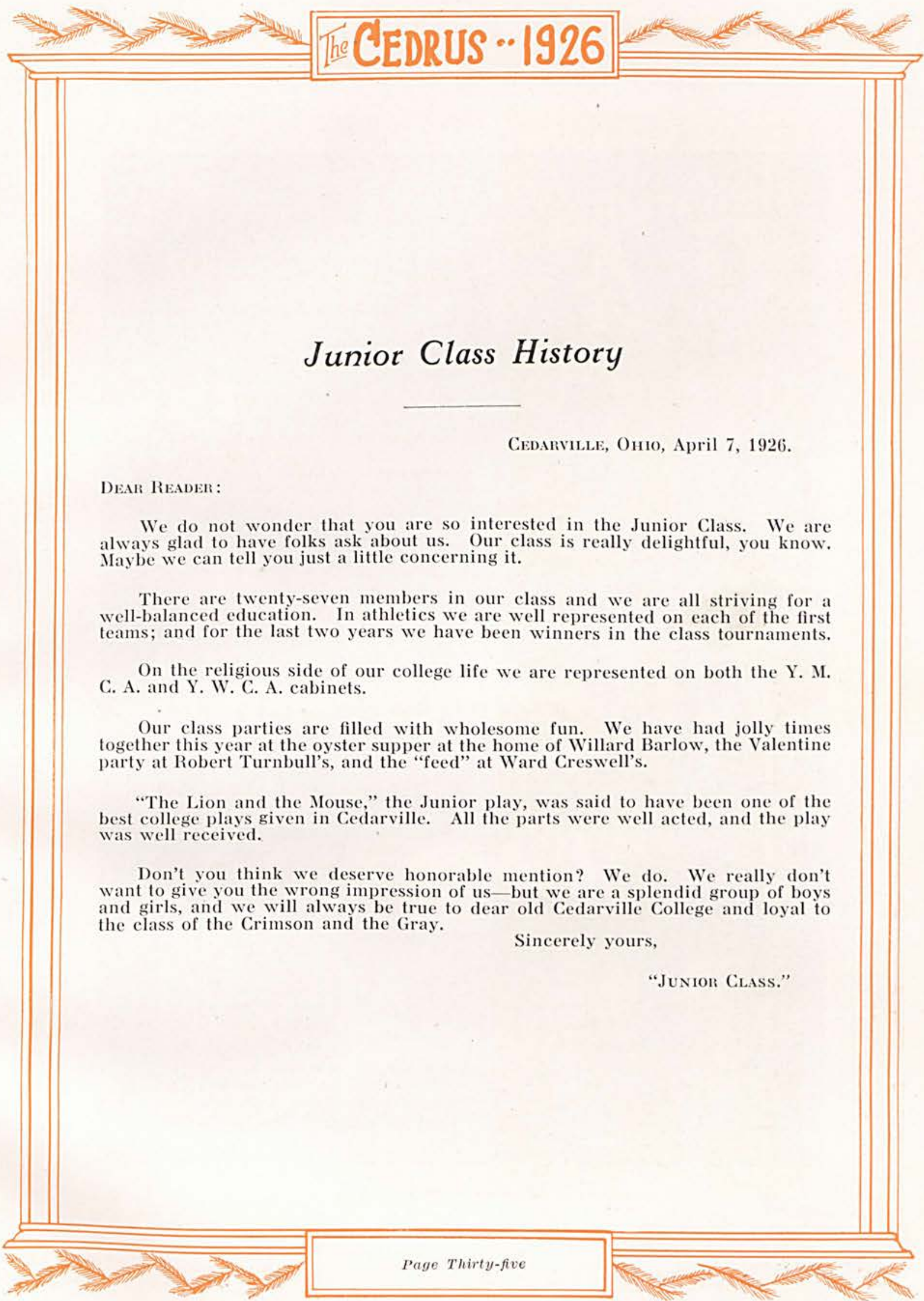




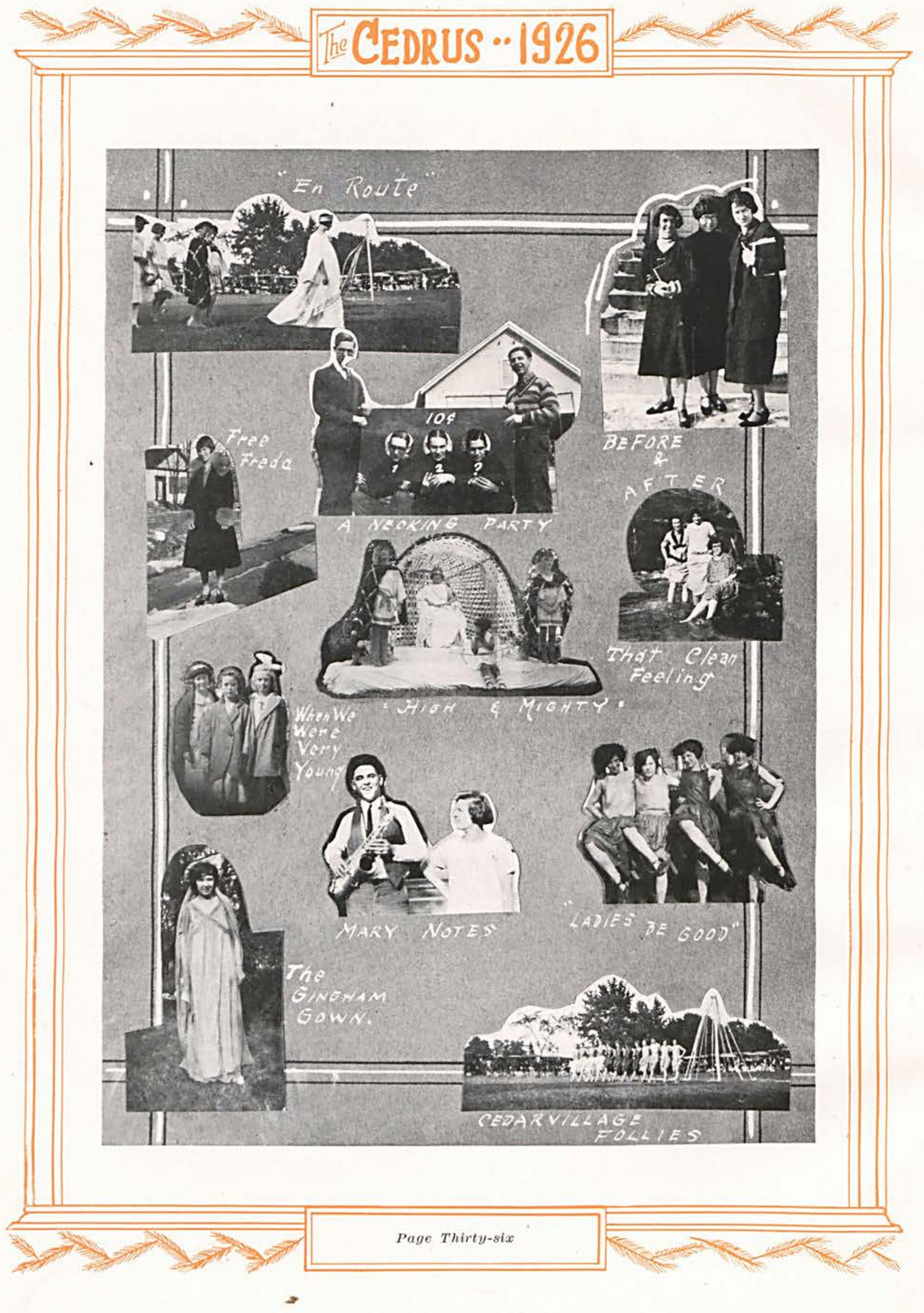




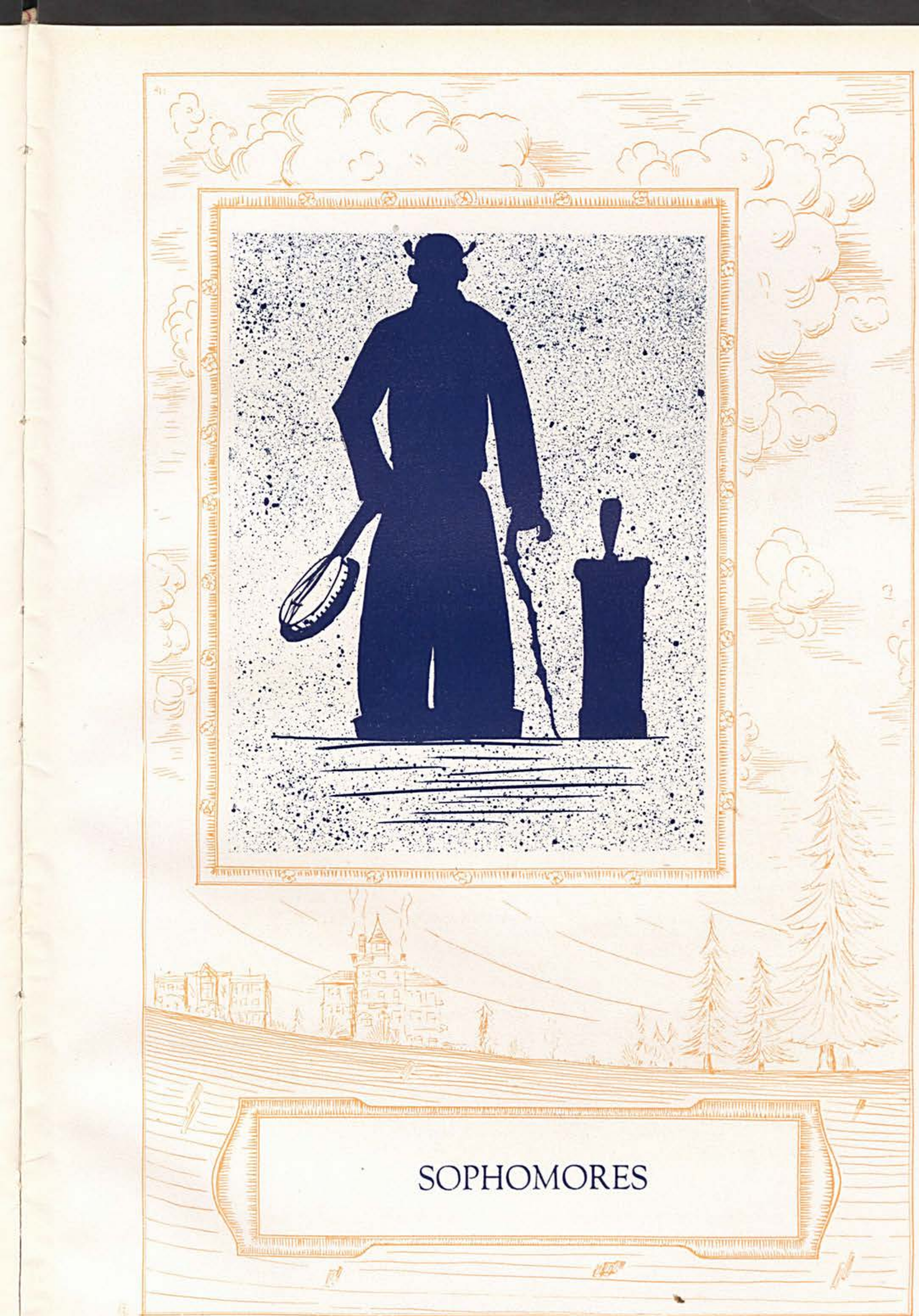





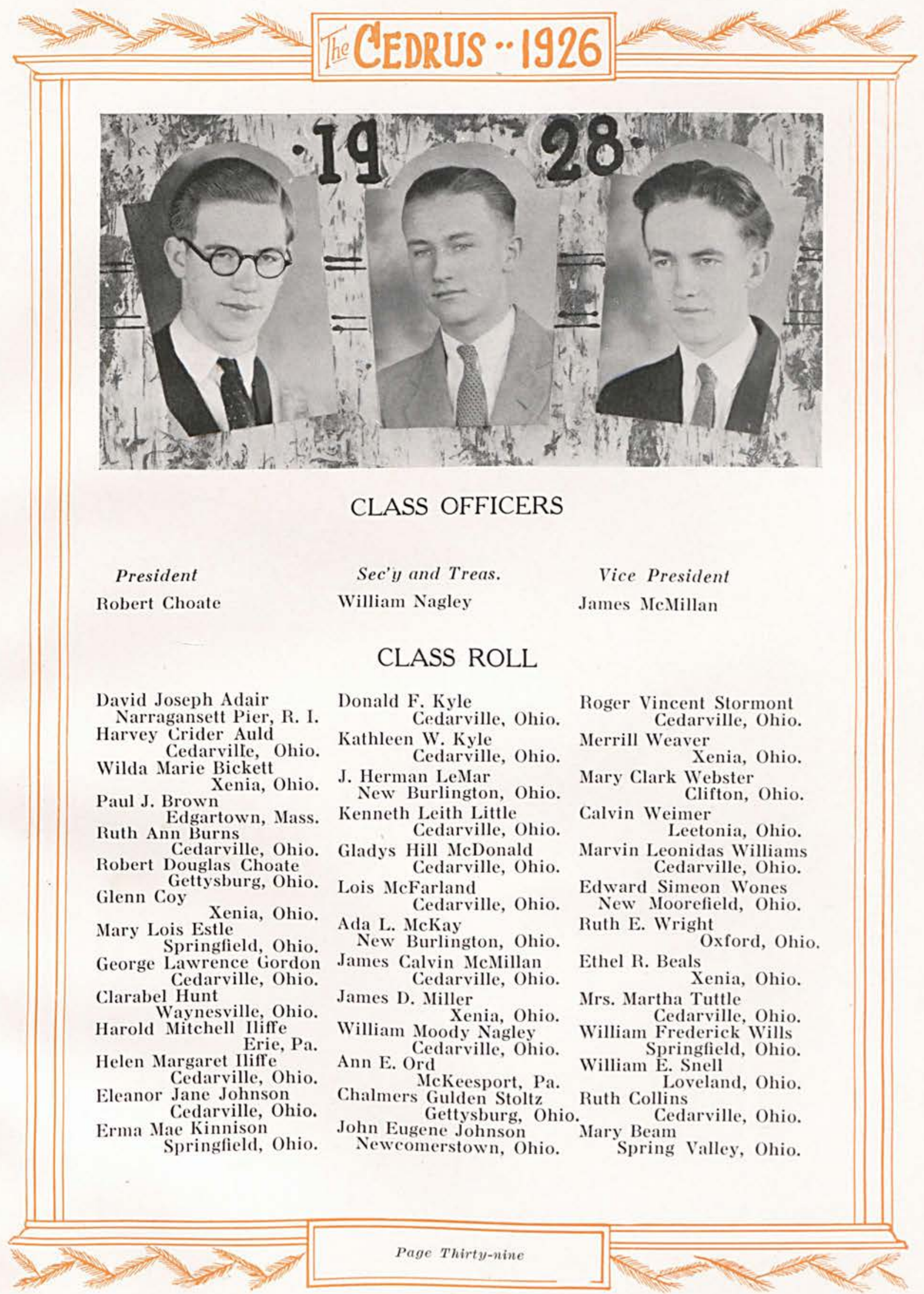




\section{$\Rightarrow$ [LEDEDUS $\cdot 1926$ -}

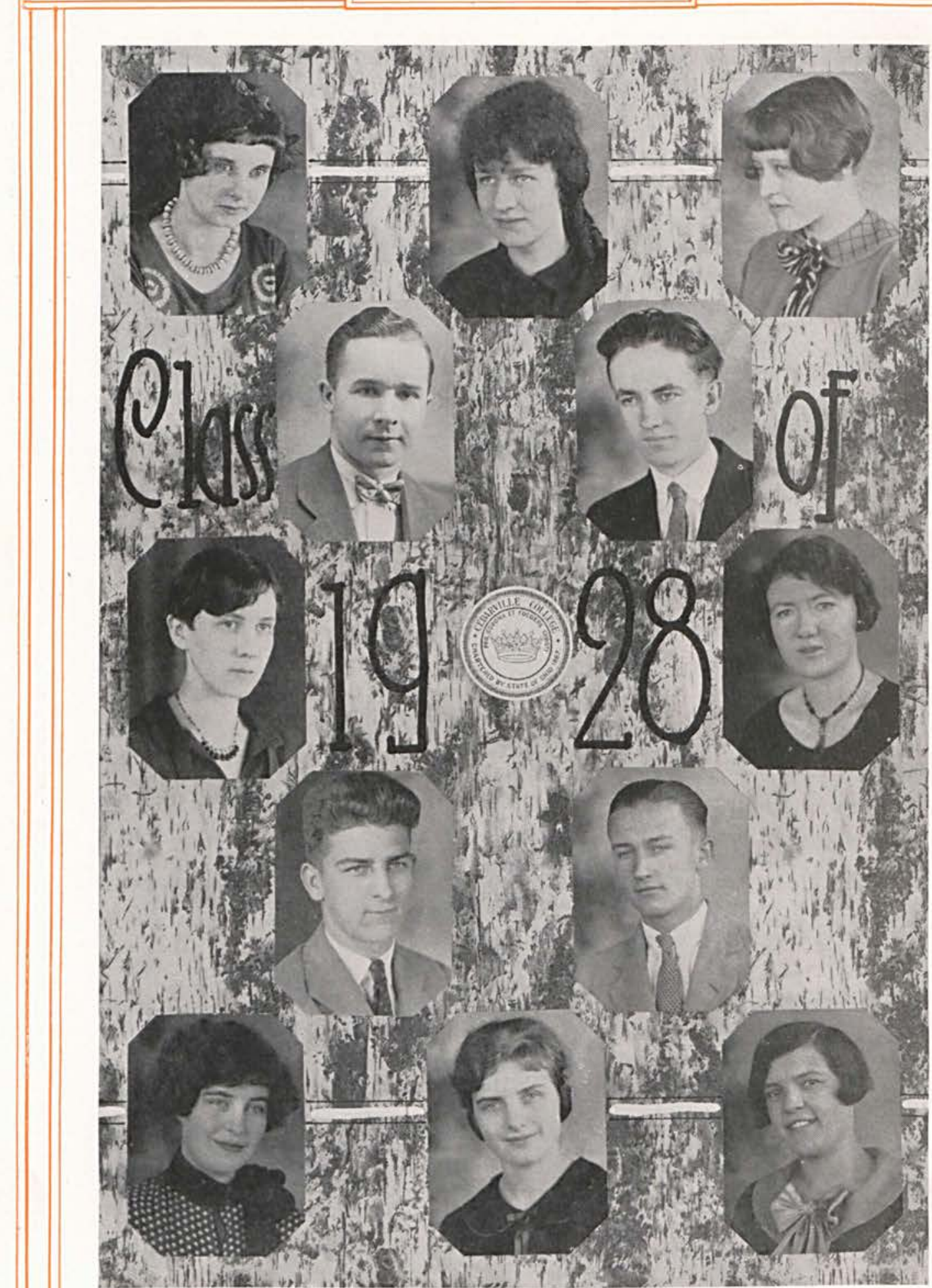

को तो

Page Forty

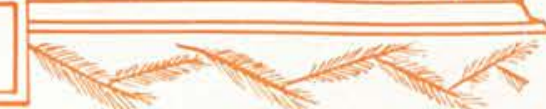




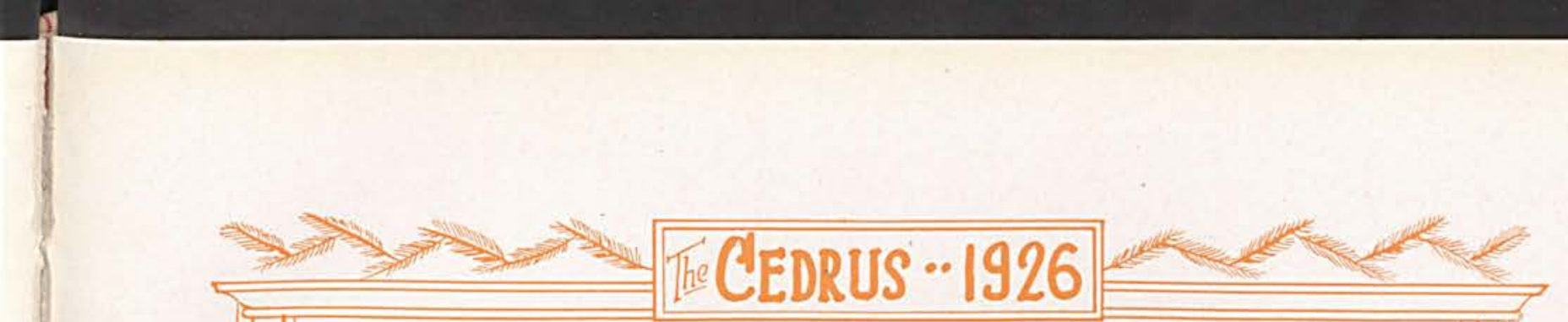

$$
\Rightarrow \Rightarrow-\text { LEDRUS.1926 }
$$
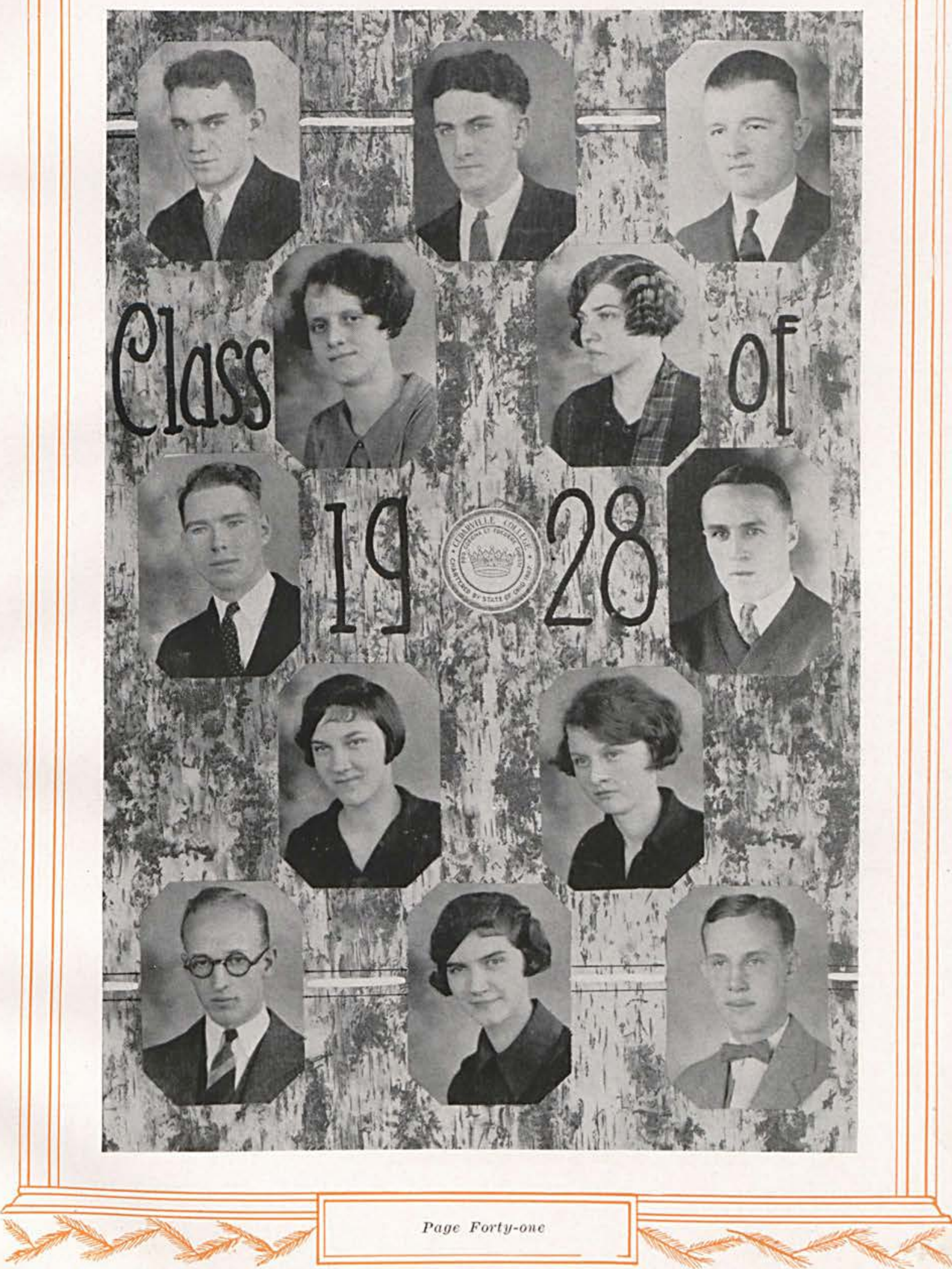
$\rightarrow$ LECEDUS $\cdot 1926$ -
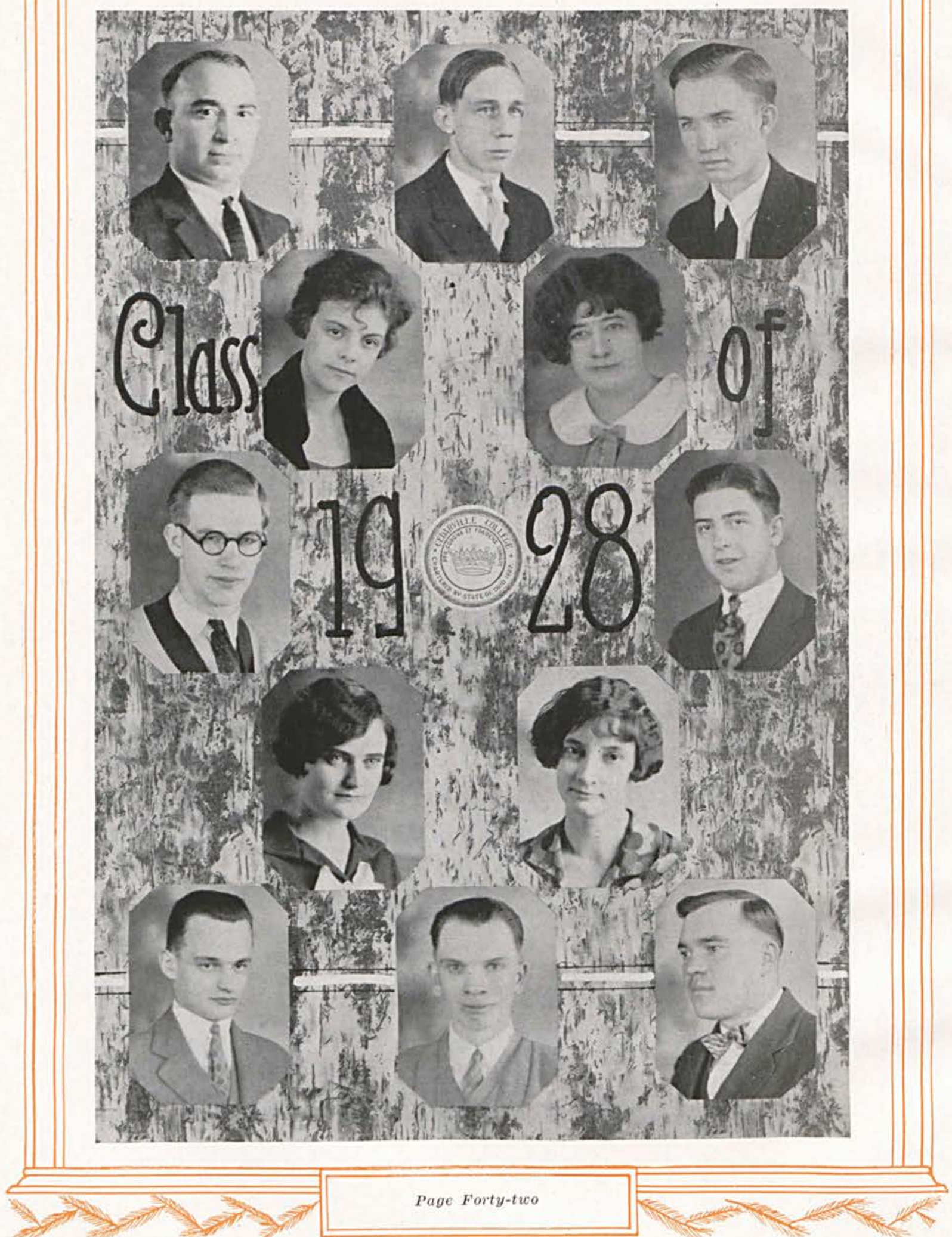


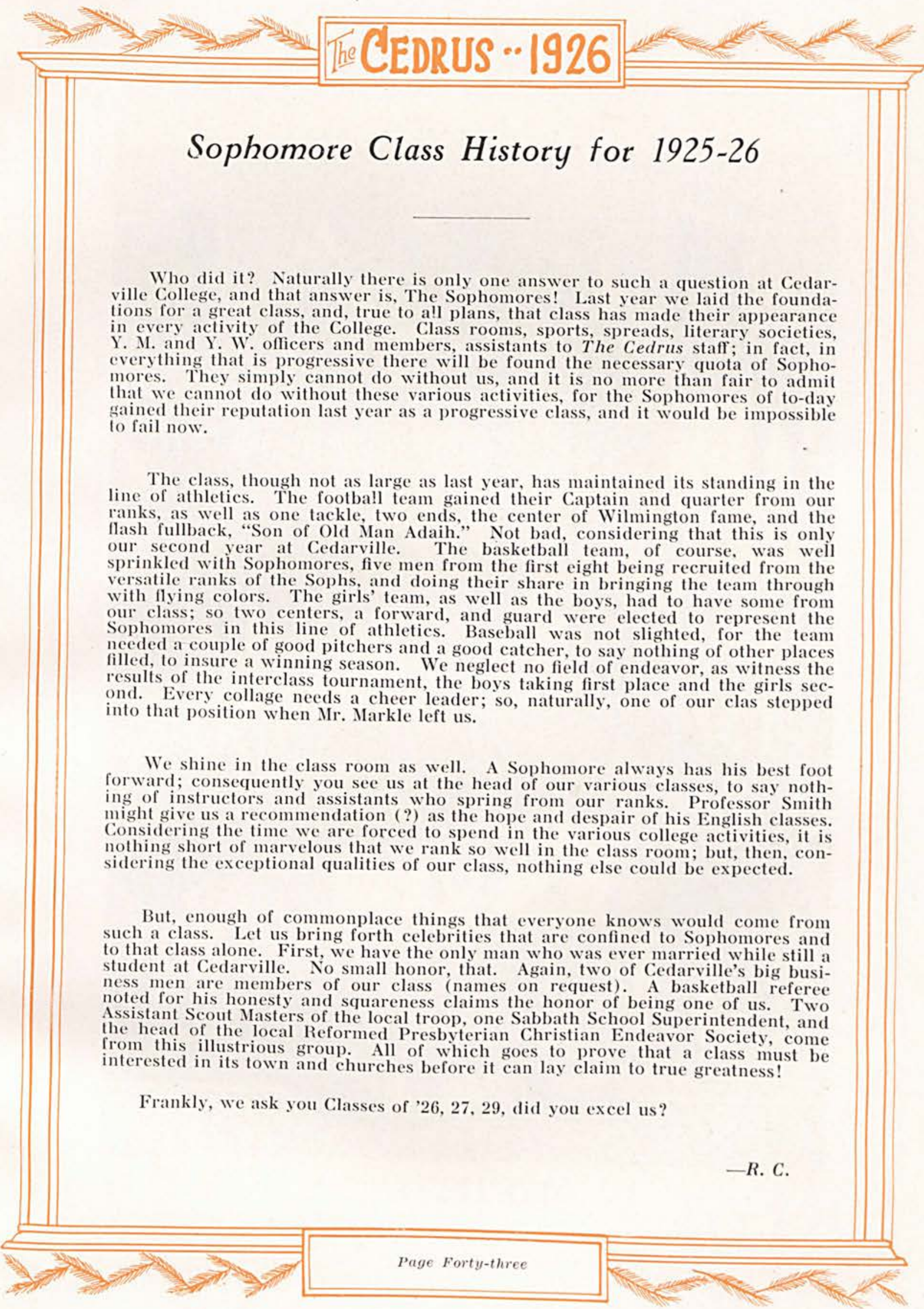




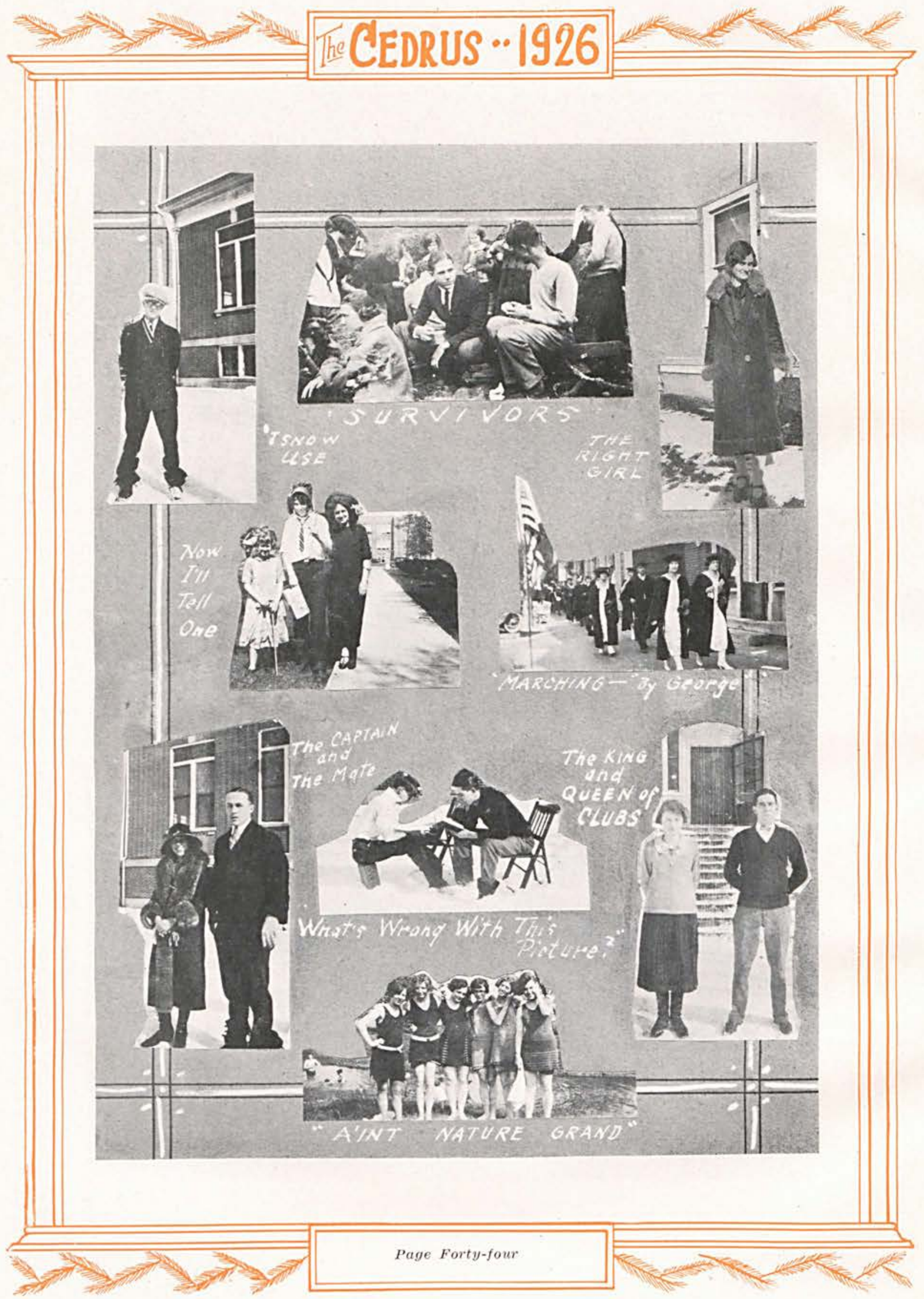




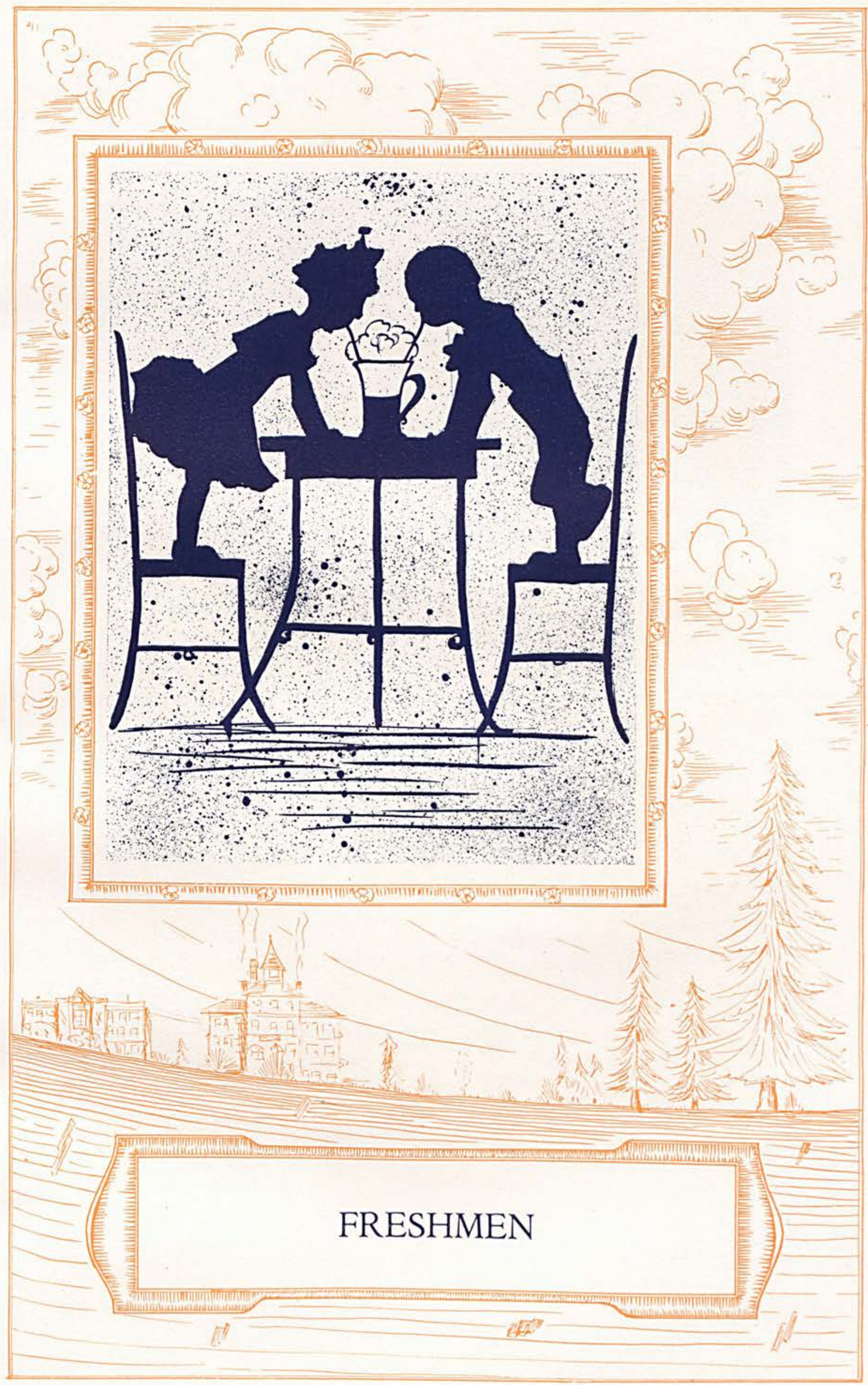





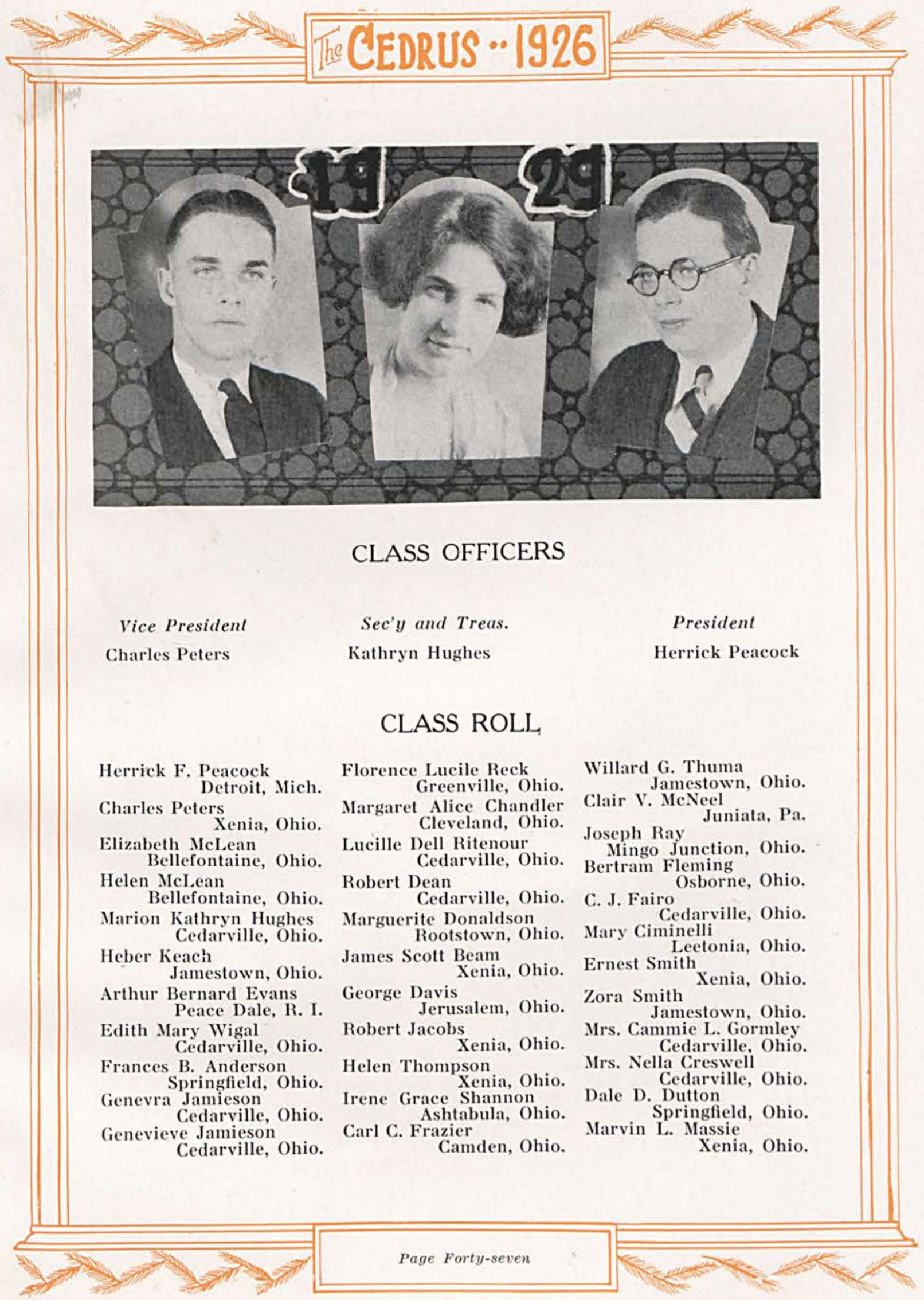




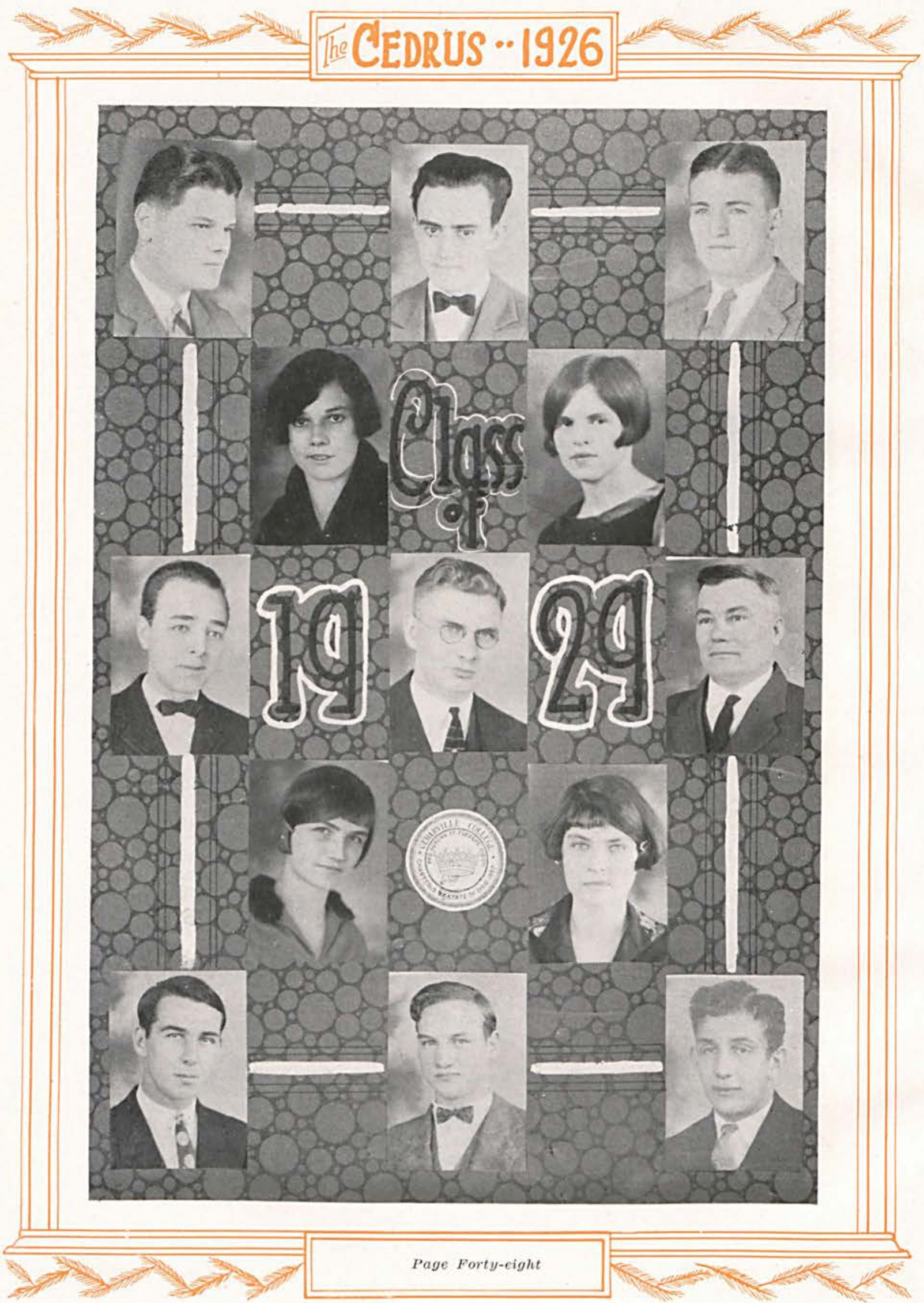




$$
\rightarrow \rightarrow-4 \text { [EDRUS } \cdot 1926 \text { - }
$$

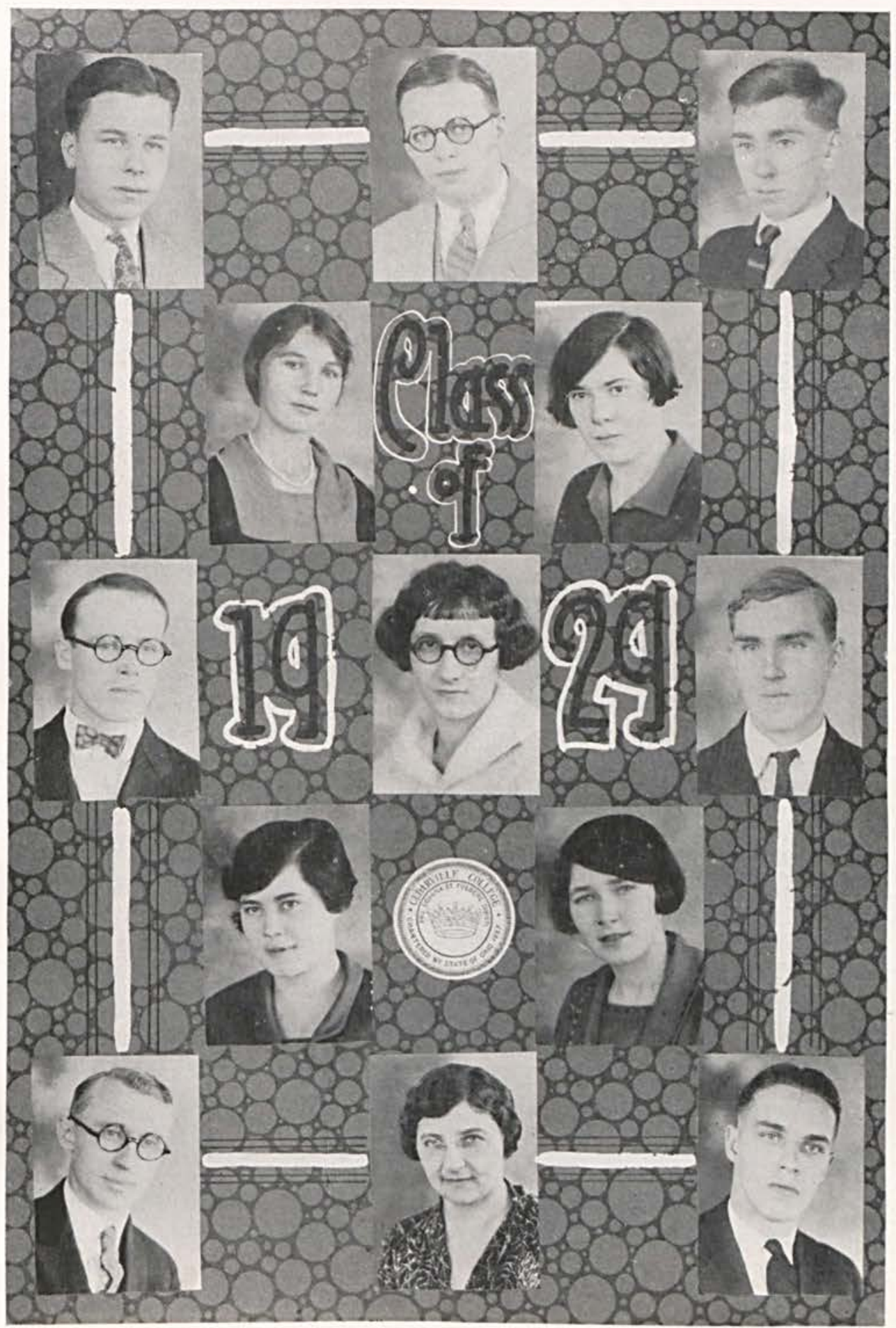

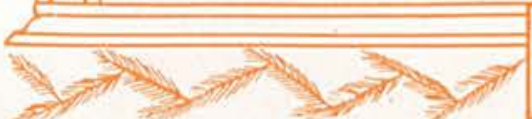

Page Forty-nine

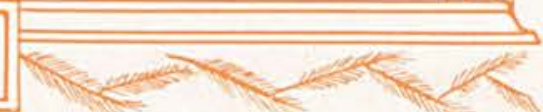




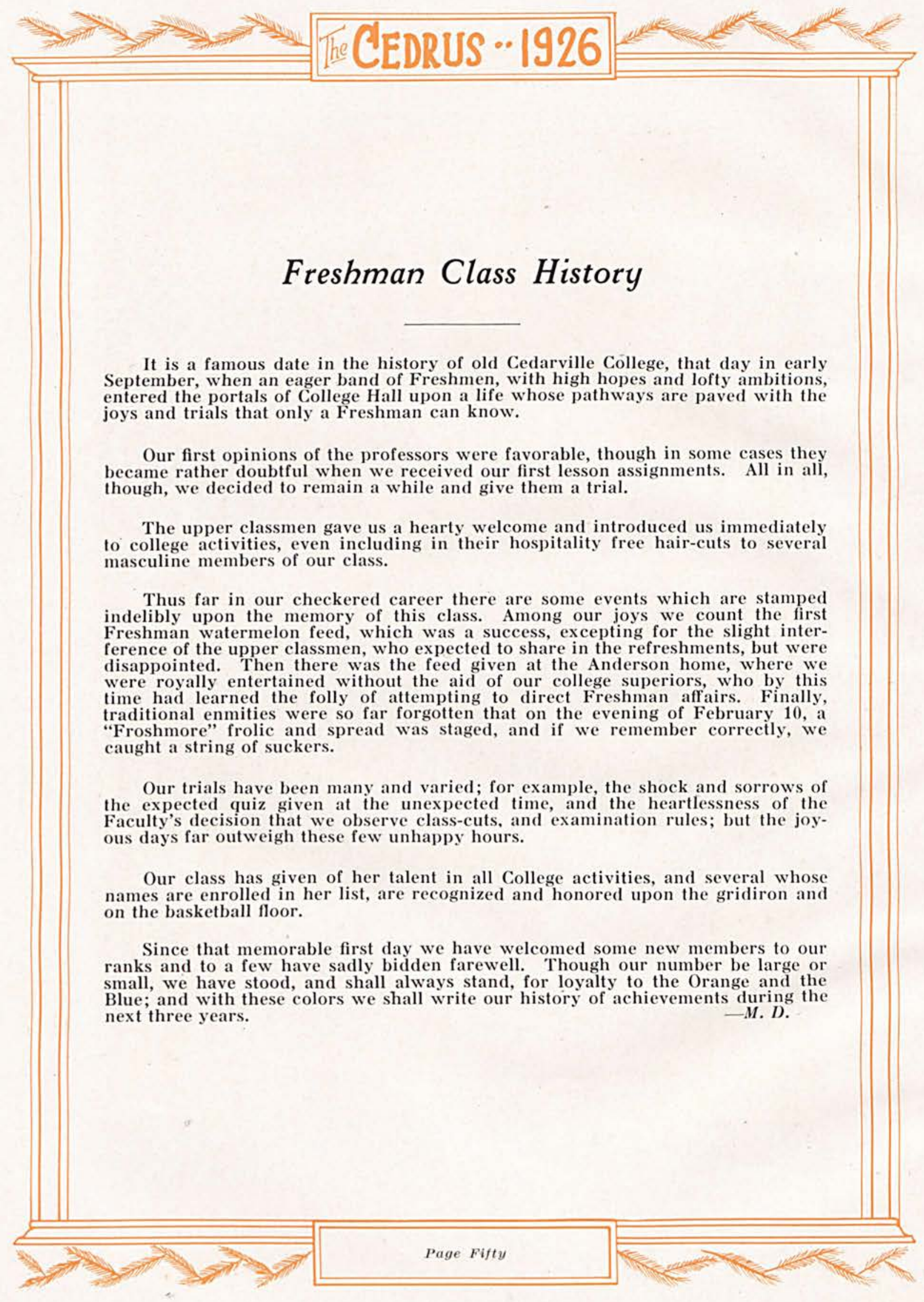




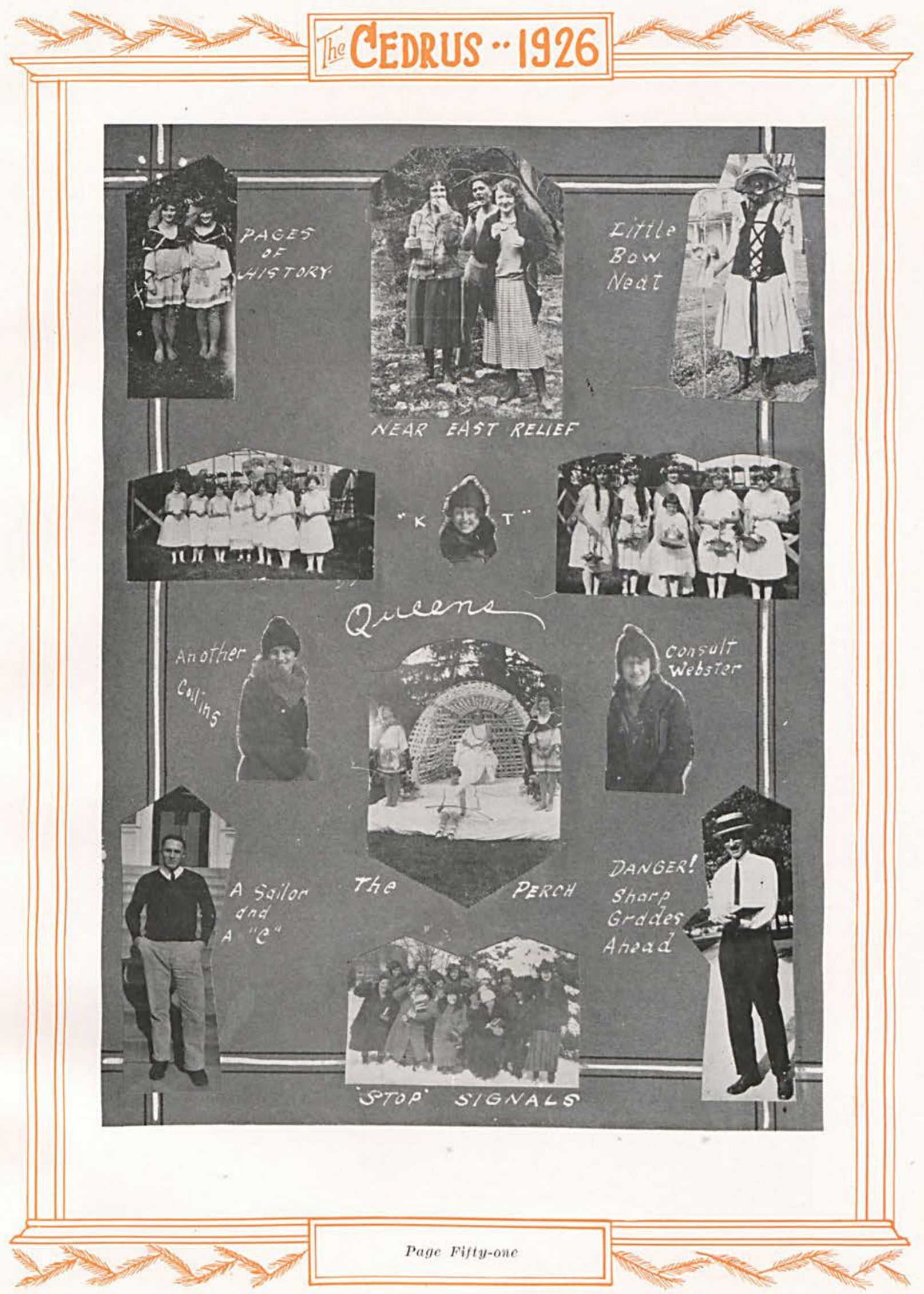




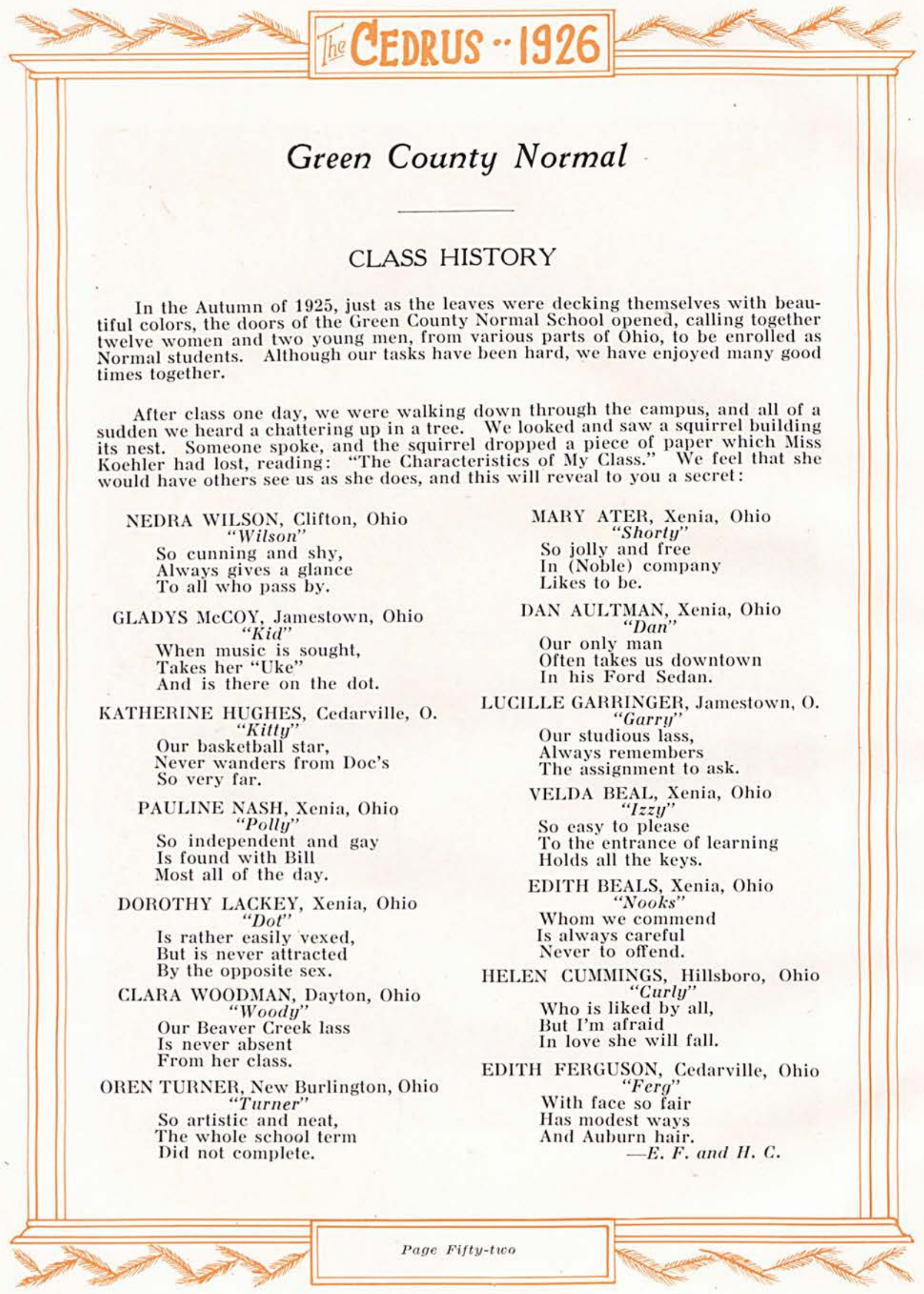




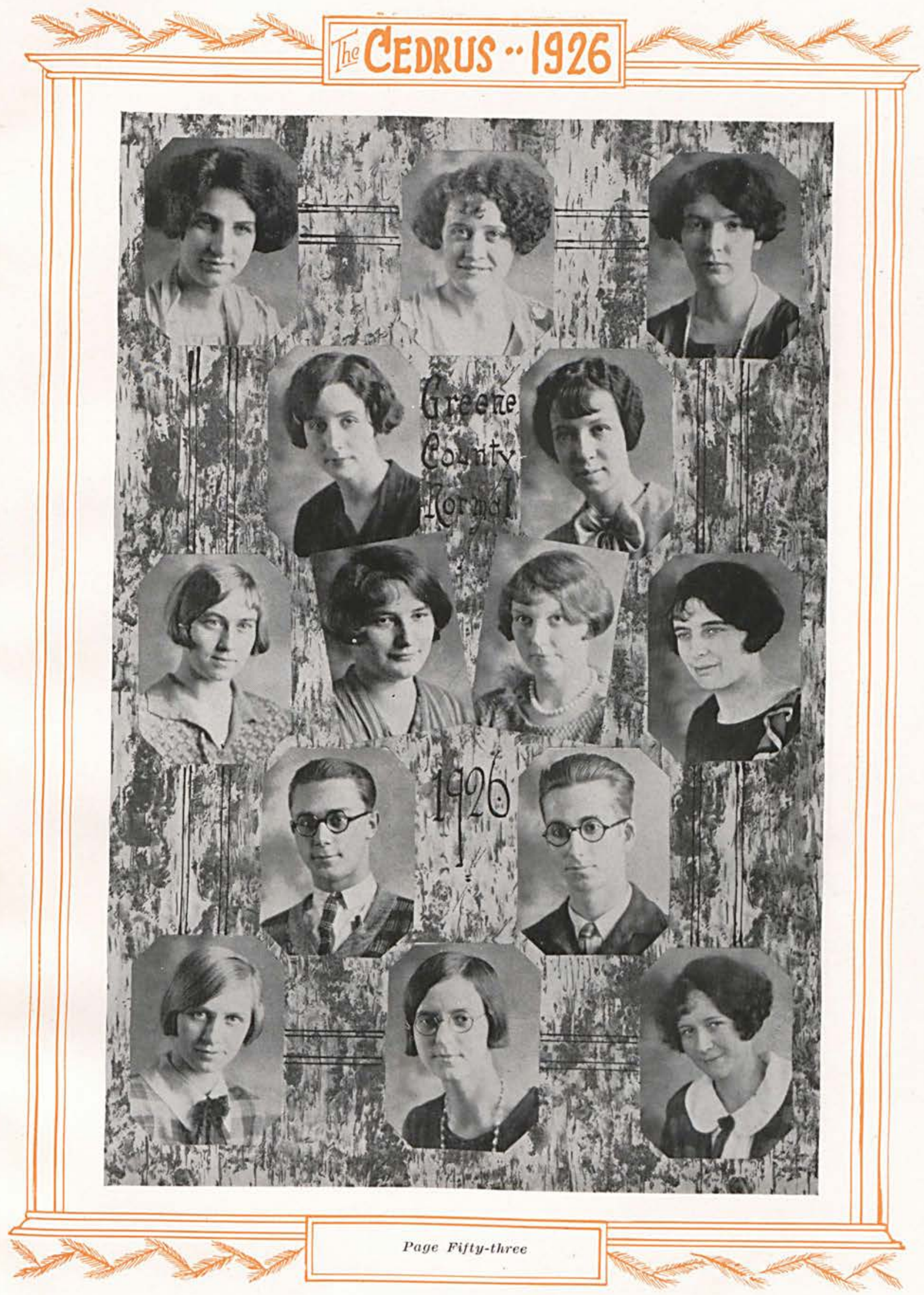




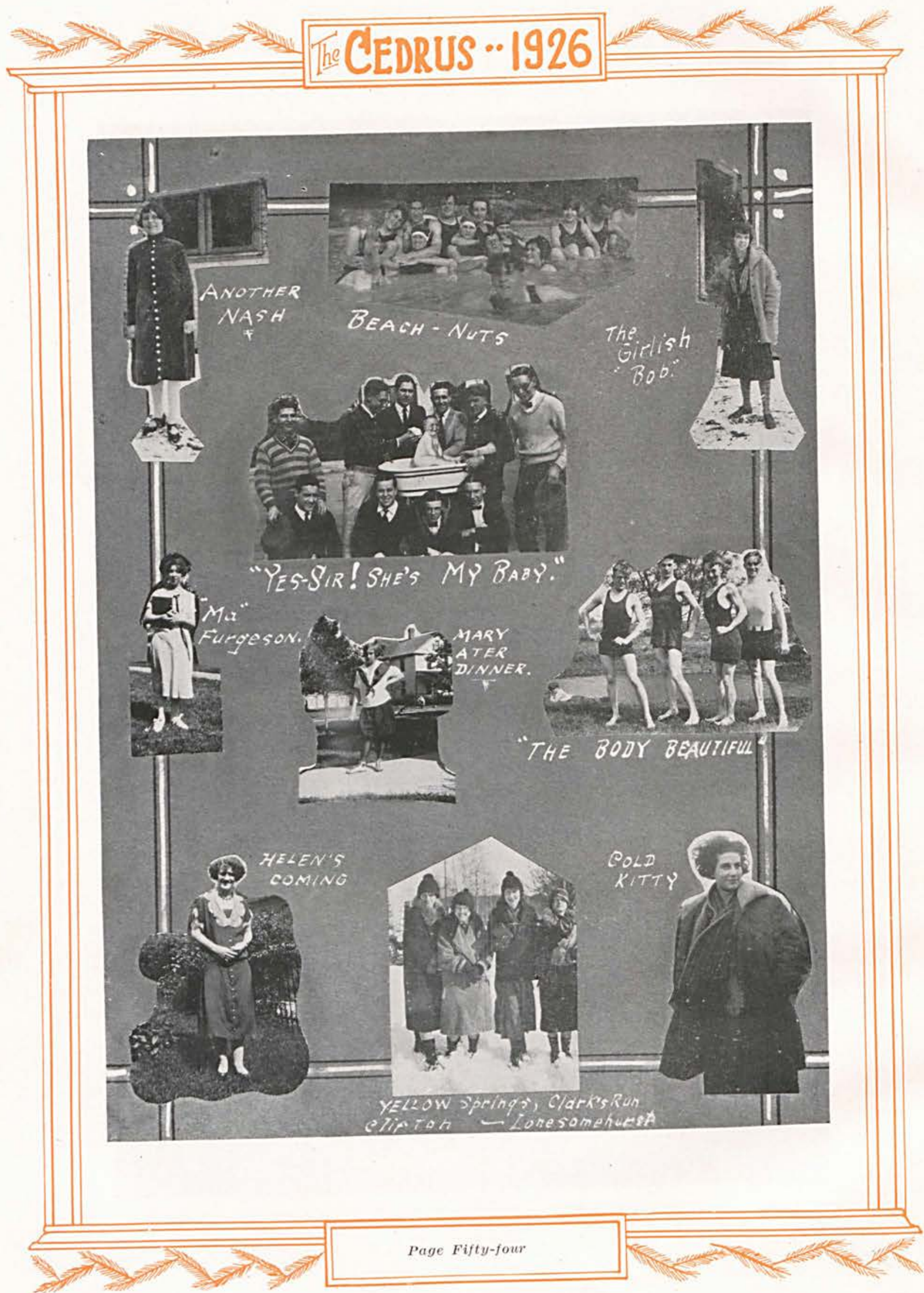




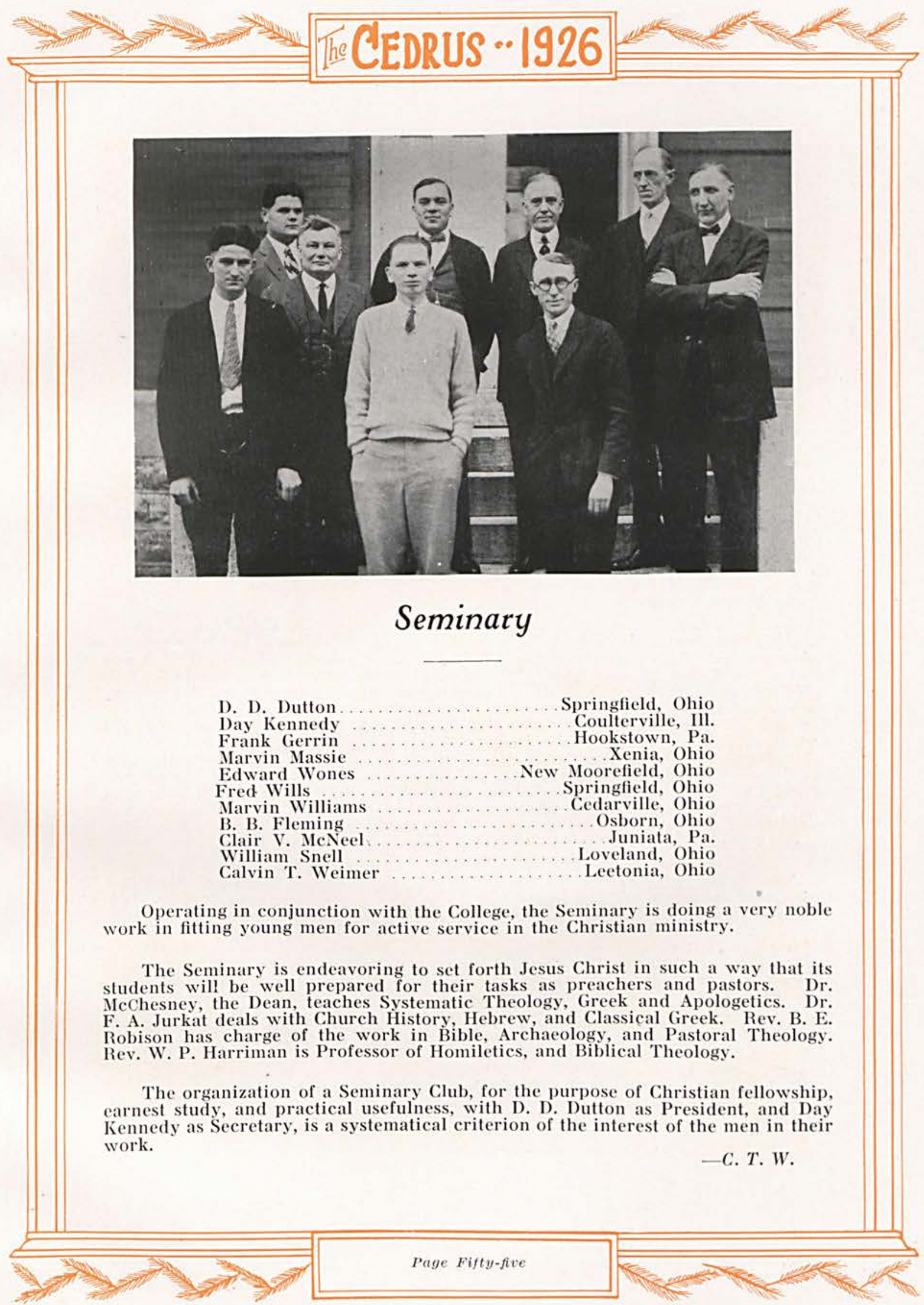




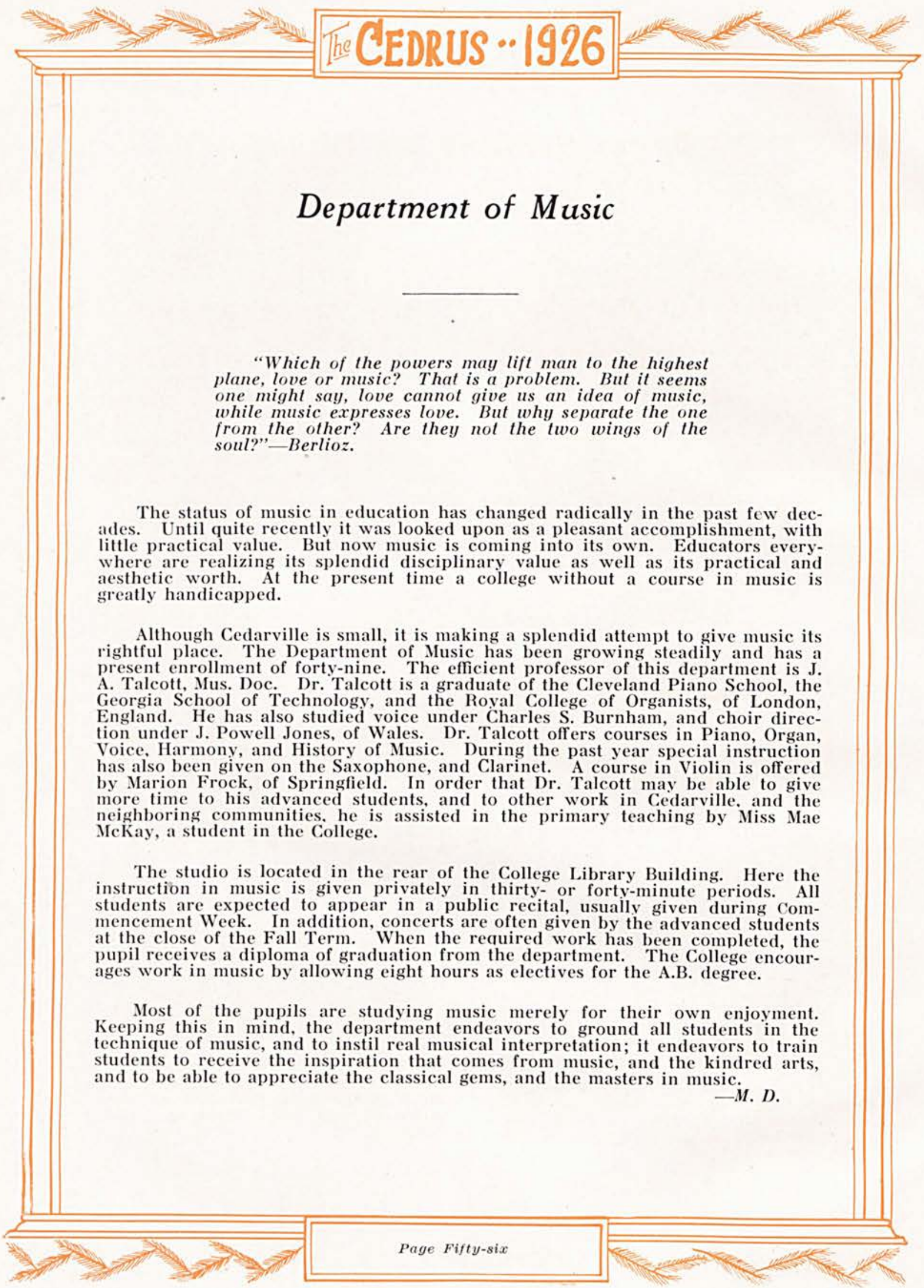




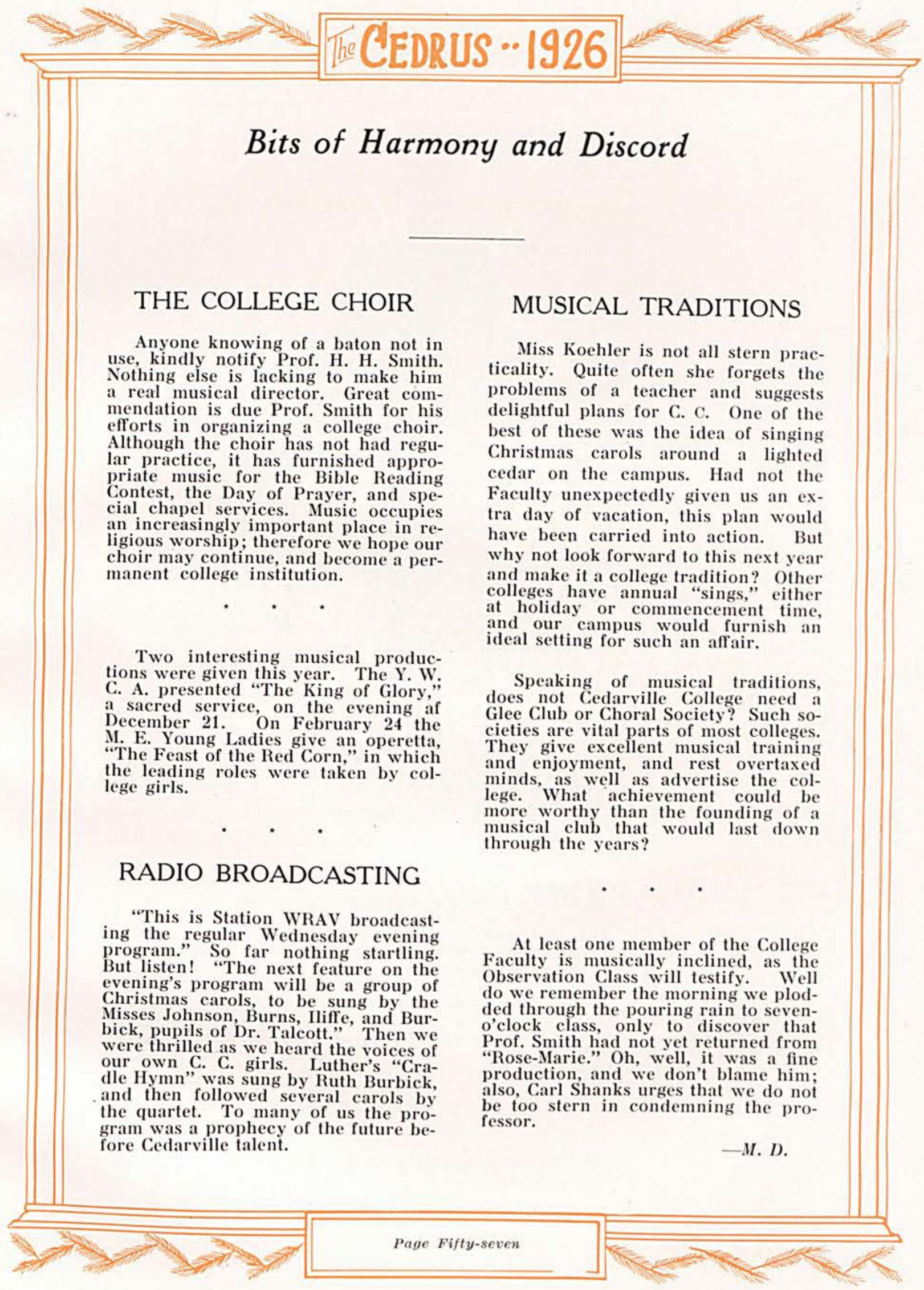




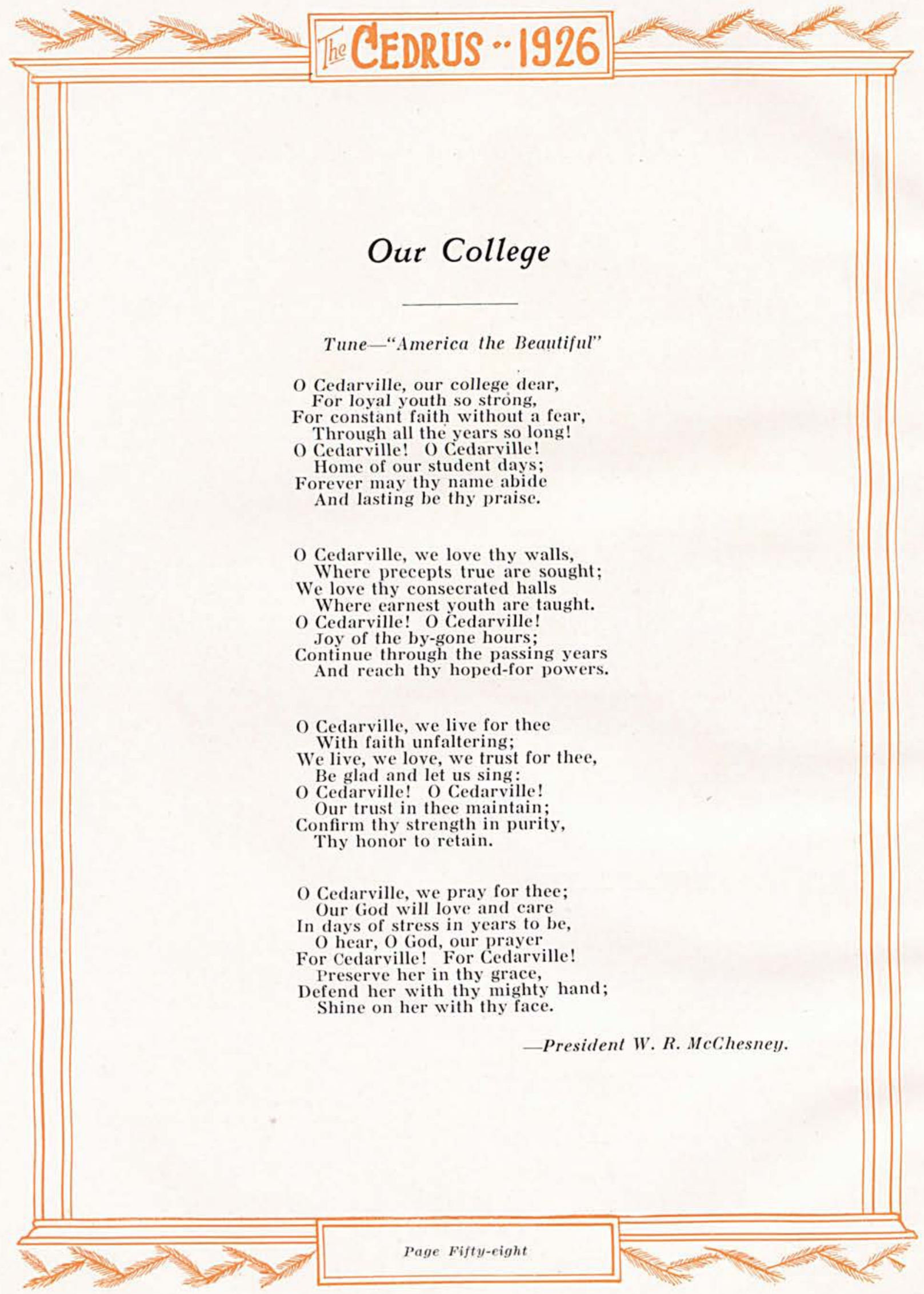




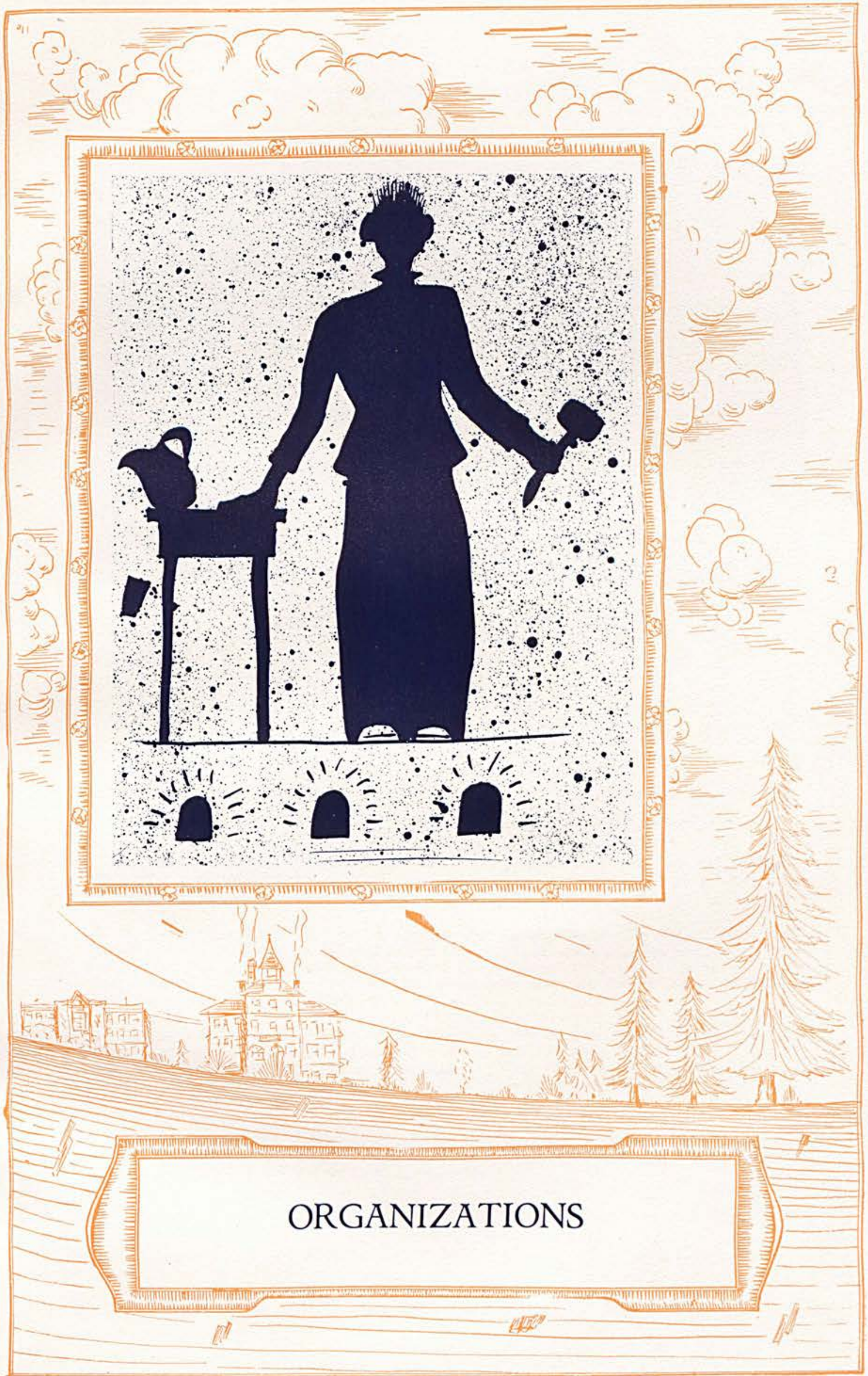





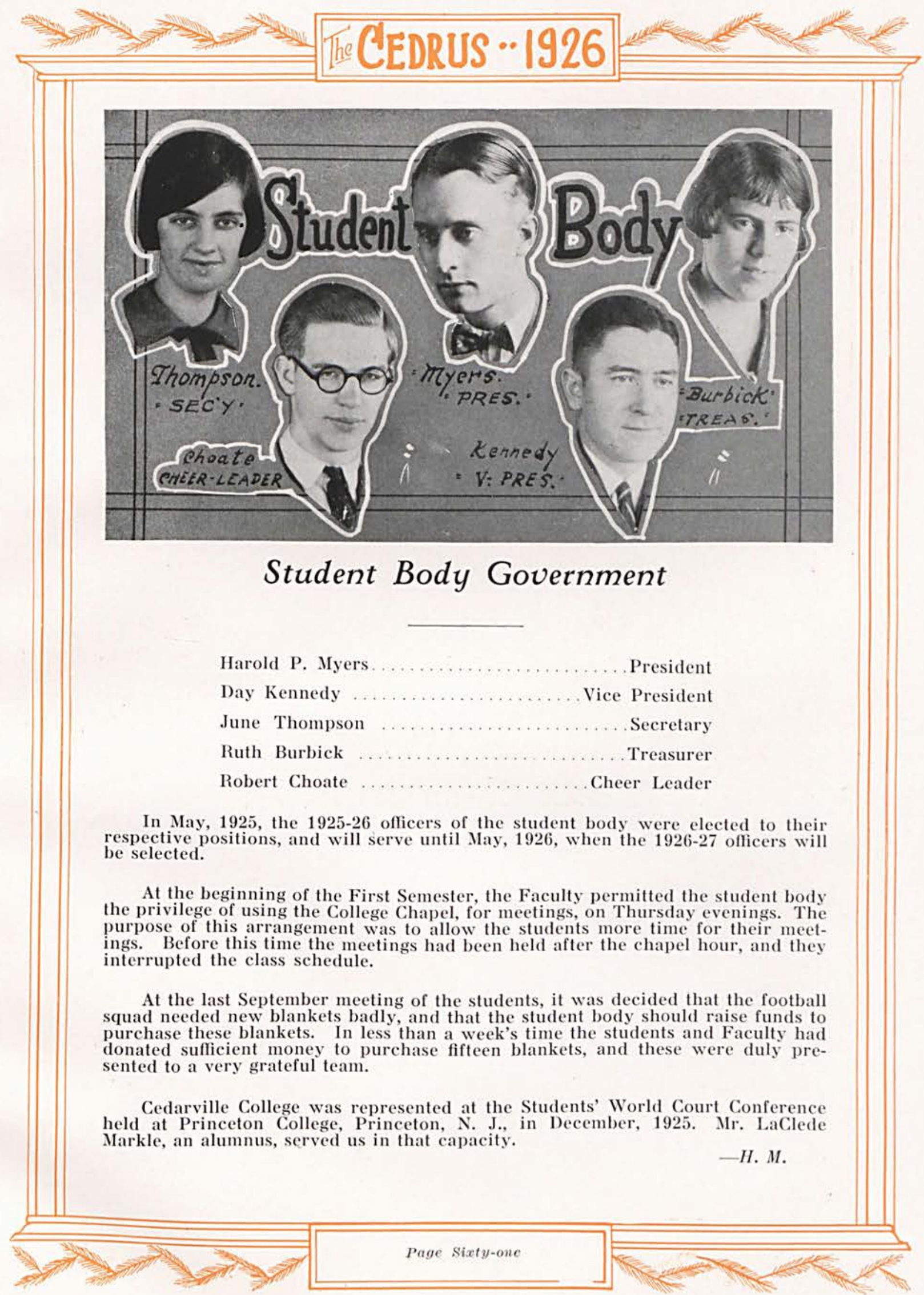




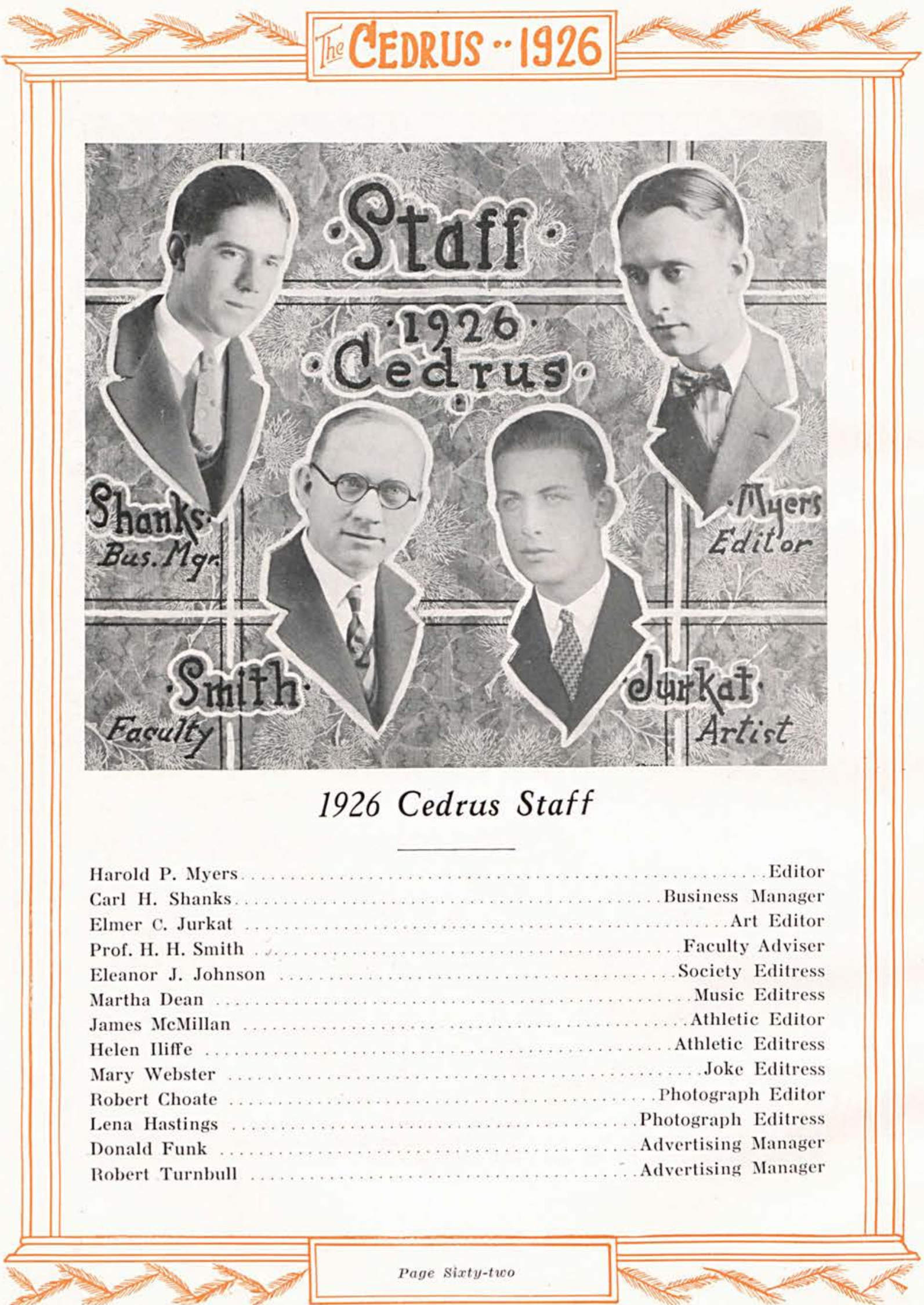





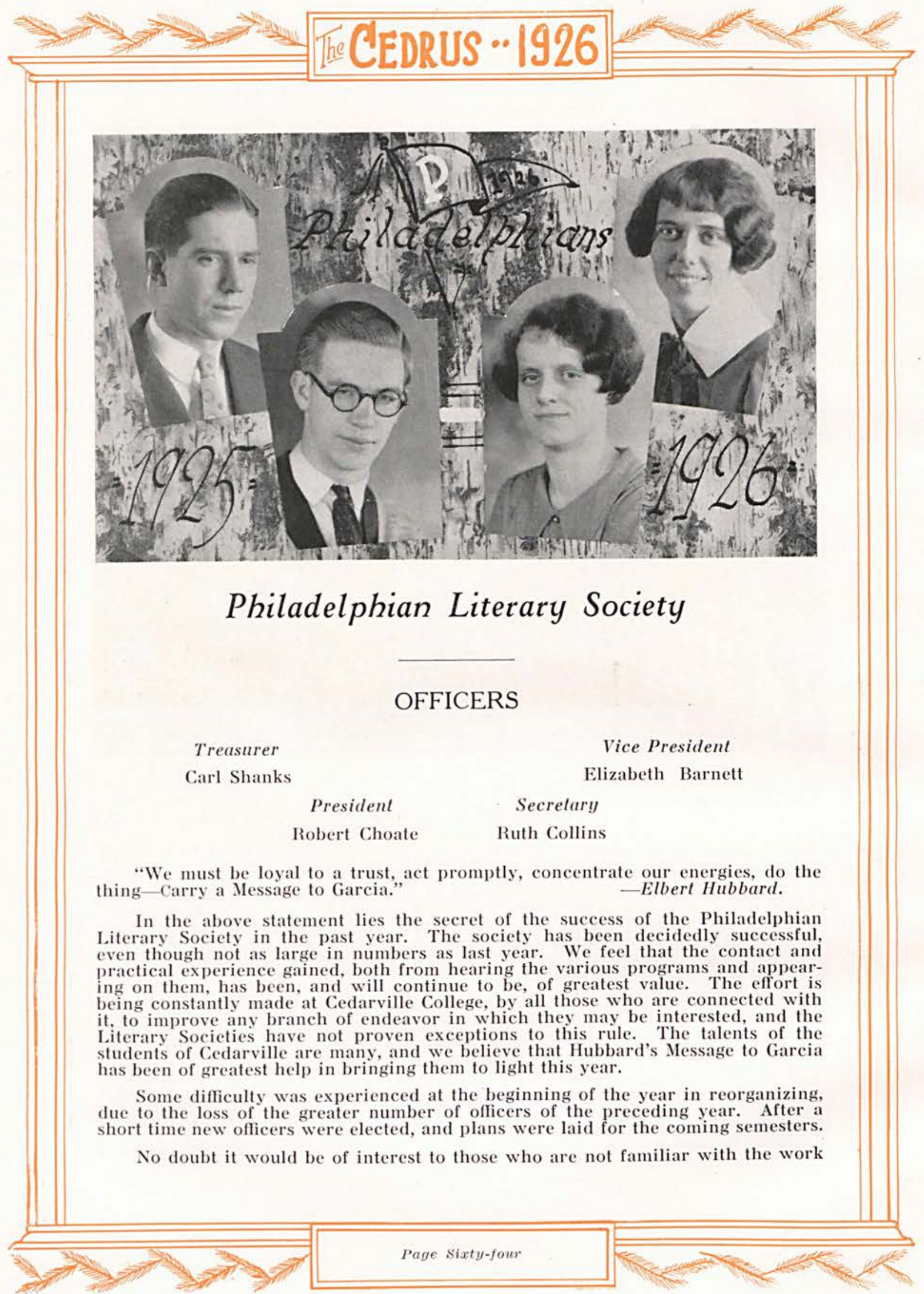




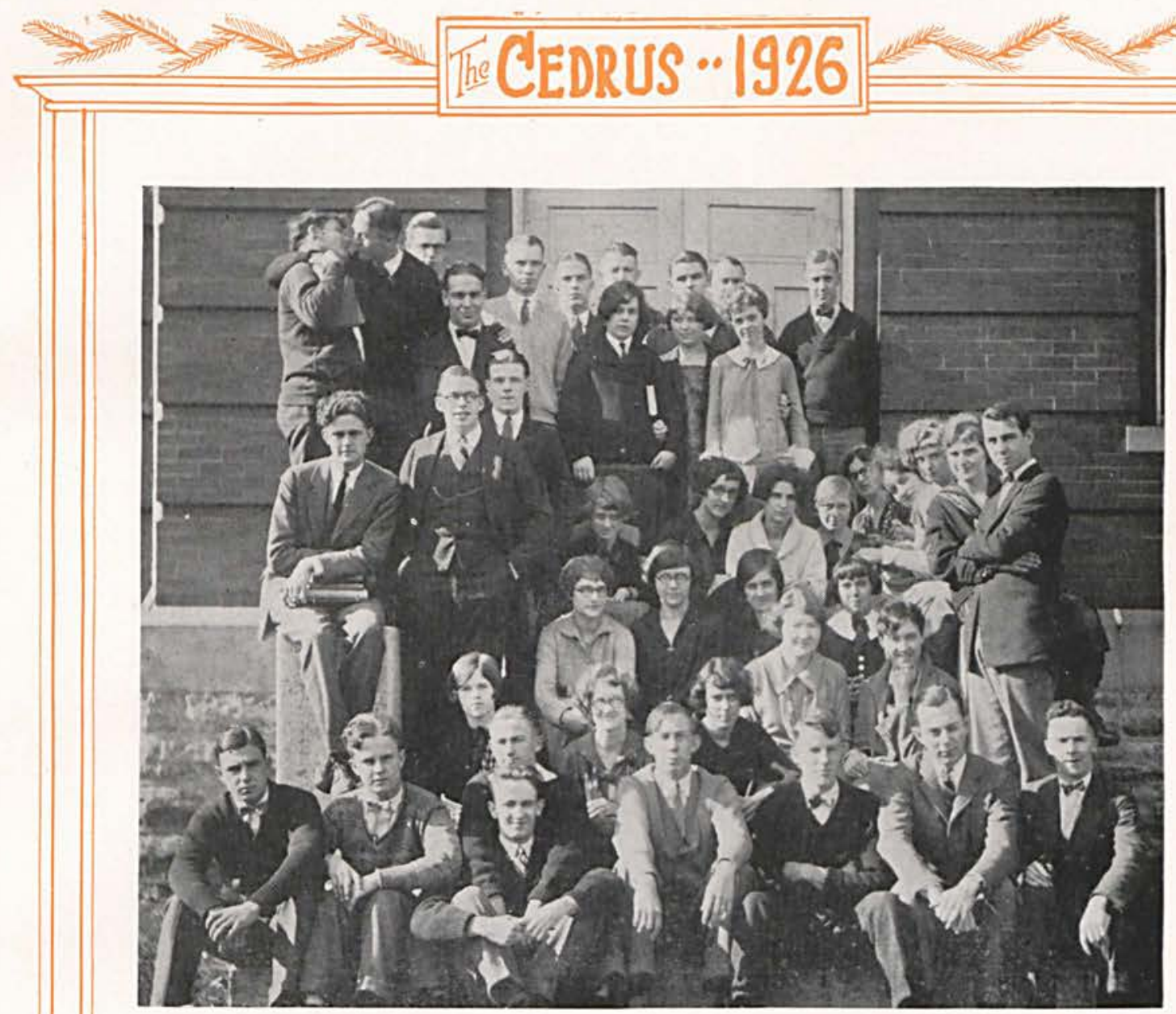

we have been doing to learn of the various plans which have proven so successful. The keynote to it all has been the idea of giving something at each meeting that would be of service to the hearers. Thus originated the plan of reviewing the life and works of some classical author or poet at each meeting. (This plan has been more than worthy of the effort expended to make it possible, as proven by the interest taken, and the praise given this particular phase of the work.) Another series of articles which aroused much favorable comment were the ones prepared and delivered by Professor Smith's South American History Class on South America. The Philadelphian Literary Society has always been noted for the originality of its members, and this has been aptly proven in the short-story contest, which took place early in the year. Musical numbers are welcome wherever a group of students are gathered together, and we have been exceptionally fortunate in that line, an extensive and varied program having been one of the chief attractions throughout the year. Another plan which promises to be of more than common interest is the reviewing each meeting of the hobby of some one of the members. Though the main idea throughout the year has been to give practical benefit, the lighter side has not been neglected, and many amusing sketches and dialogues have been given from time to time.

We believe that the societies are improving from year to year, and feel safe in saying that this year's work in the Philadelphian Hall has poven a success in every way. An appreciation of literature, music, and art is needed by everyone, and any work which gives this to us necessarily ranks high. In the years to come, Philadelphians, let us make every effort to improve our society and ever keep in mind the "Message to Garcia."

$-R . C$.

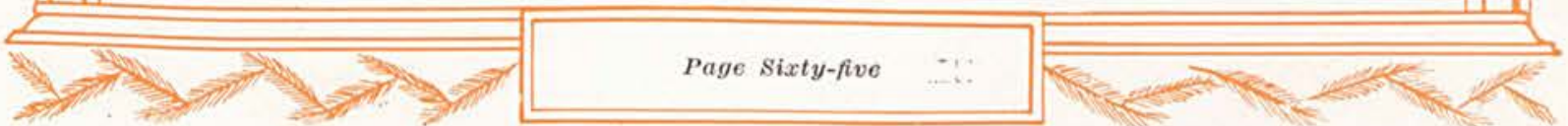




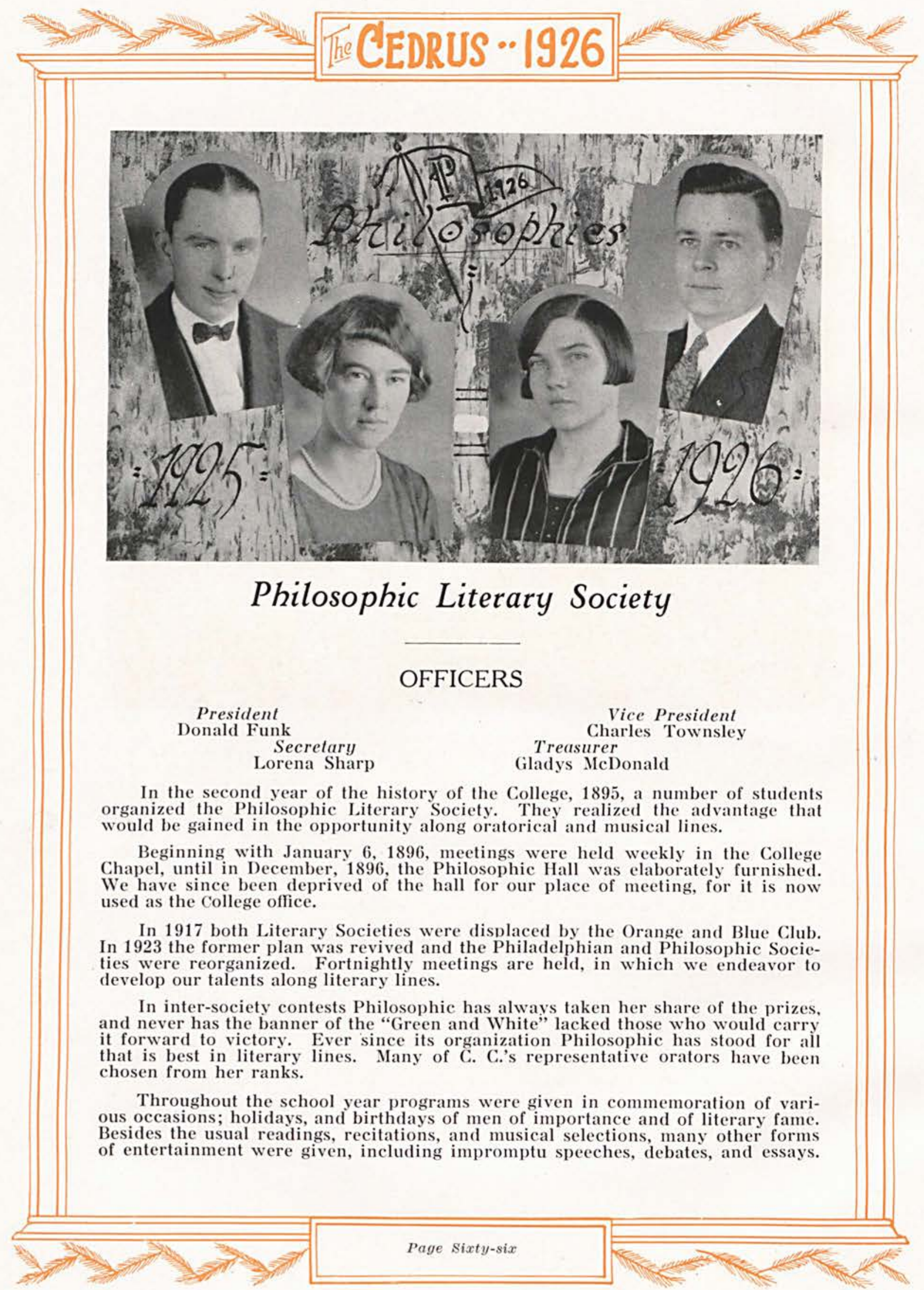




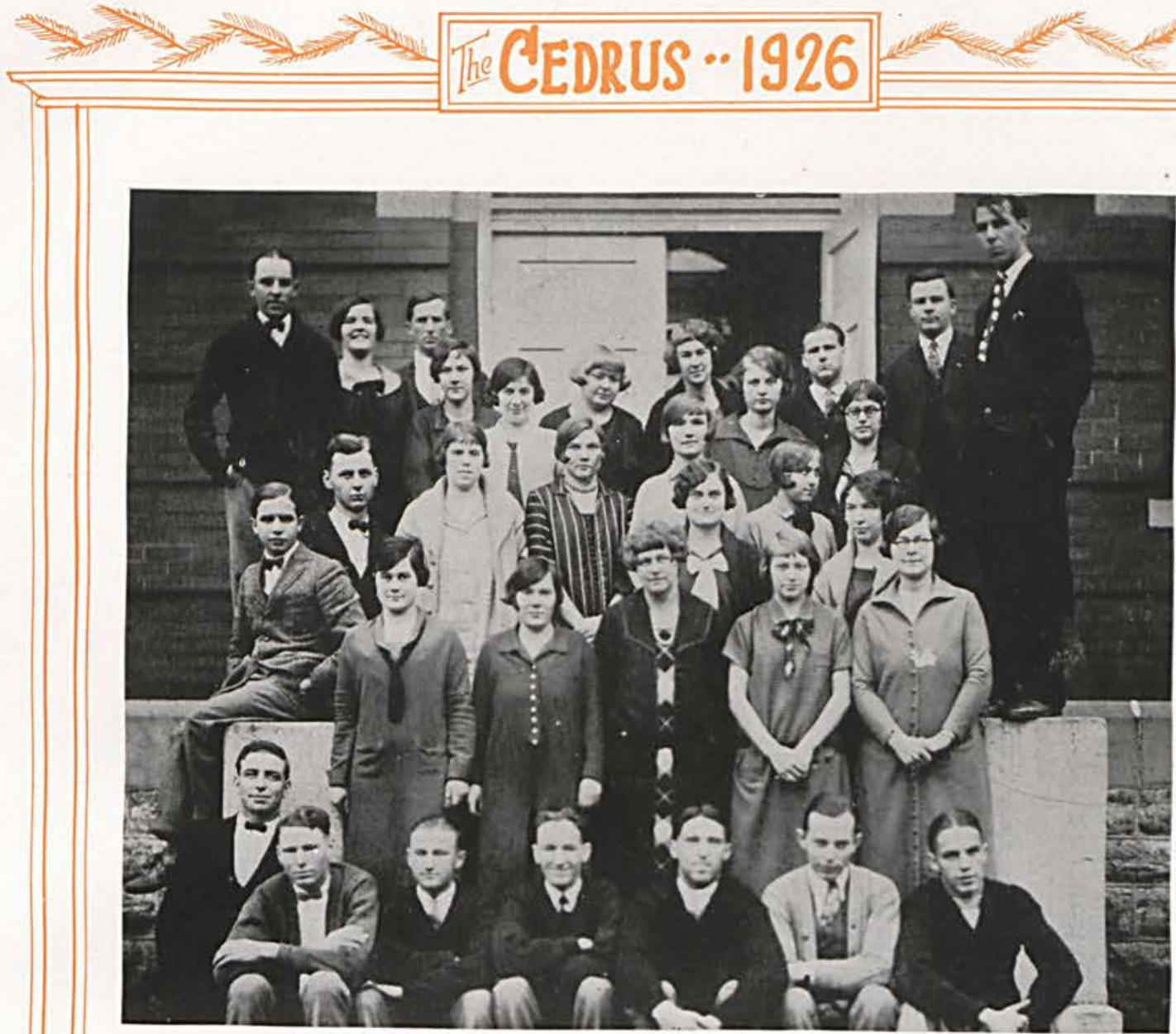

Realizing that no organization is complete without the social activities, our society has not neglected this phase of life. From time to time during the year a short social hour was held, sometimes after the regular literary program, and business; and sometimes the whole evening was given over to the Entertainment Committee of the society. No one sat back and looked on, because love for fun was manifested by all in the good, lively games. The enthusiasm of the leaders as they directed the games helped to inspire the players to even greater enthusiasm.

Probably the most typical and most enjoyable social event in which the society participated was the commemoration of Washington's birthday. After the rendering of a very fitting program, a goodly number of the members remained to be further reminded of the "Father of Our Country" by taking part in games suitable for the occasion. Nor must we fail to mention the good home-made icecream, and the cookie hatchets, which were refused by no one.

The success of the society cannot be fully measured now, but we feel sure that it will be in the future. Each individual member who has helped arrange and render the various programs has received some benefit which will remain with him throughout the years to come. We feel sure that no discredit will be brought to old C. C., but rather that our Alma Mater will be an institution of more fame because of us. Although it seemed hard for us to perform, yet we trust that this initial step in appearing before the public will be the stepping stone that will cause our present members in later life to look back through the years with pride on the memory of the Philosophic Literary Society. -F. C. and R. W.

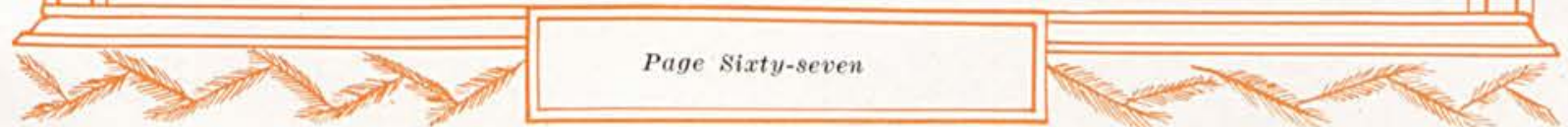




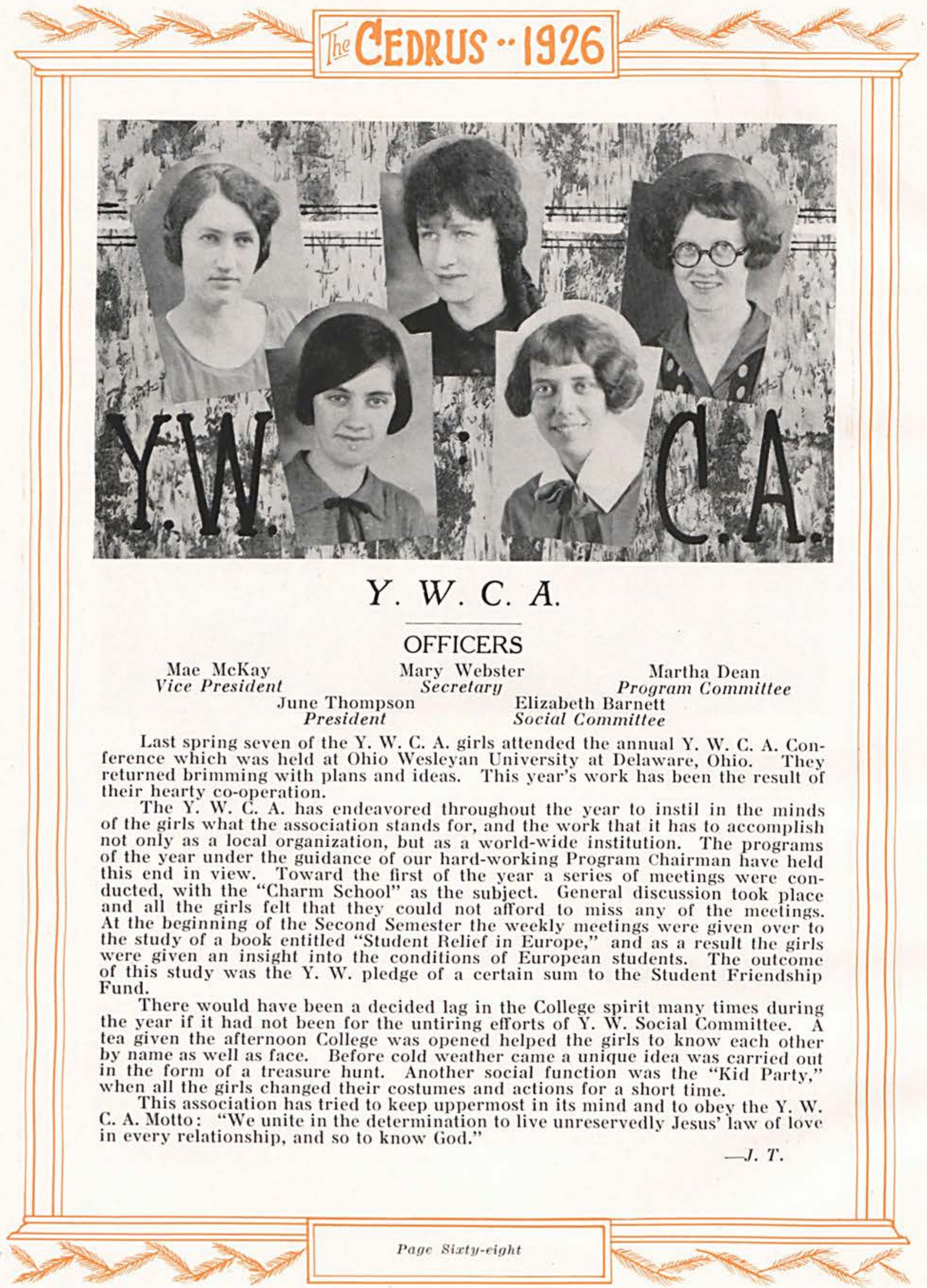




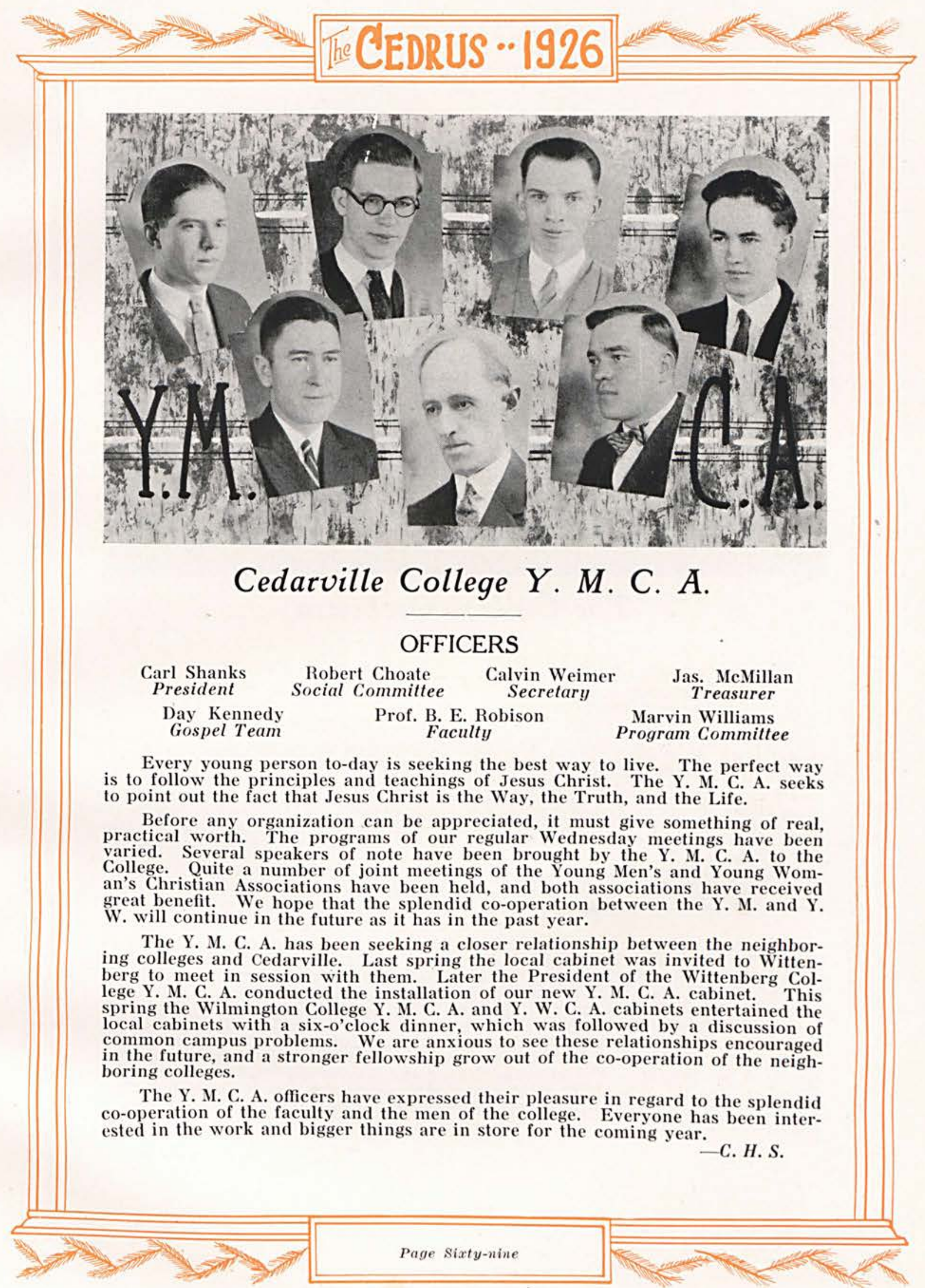




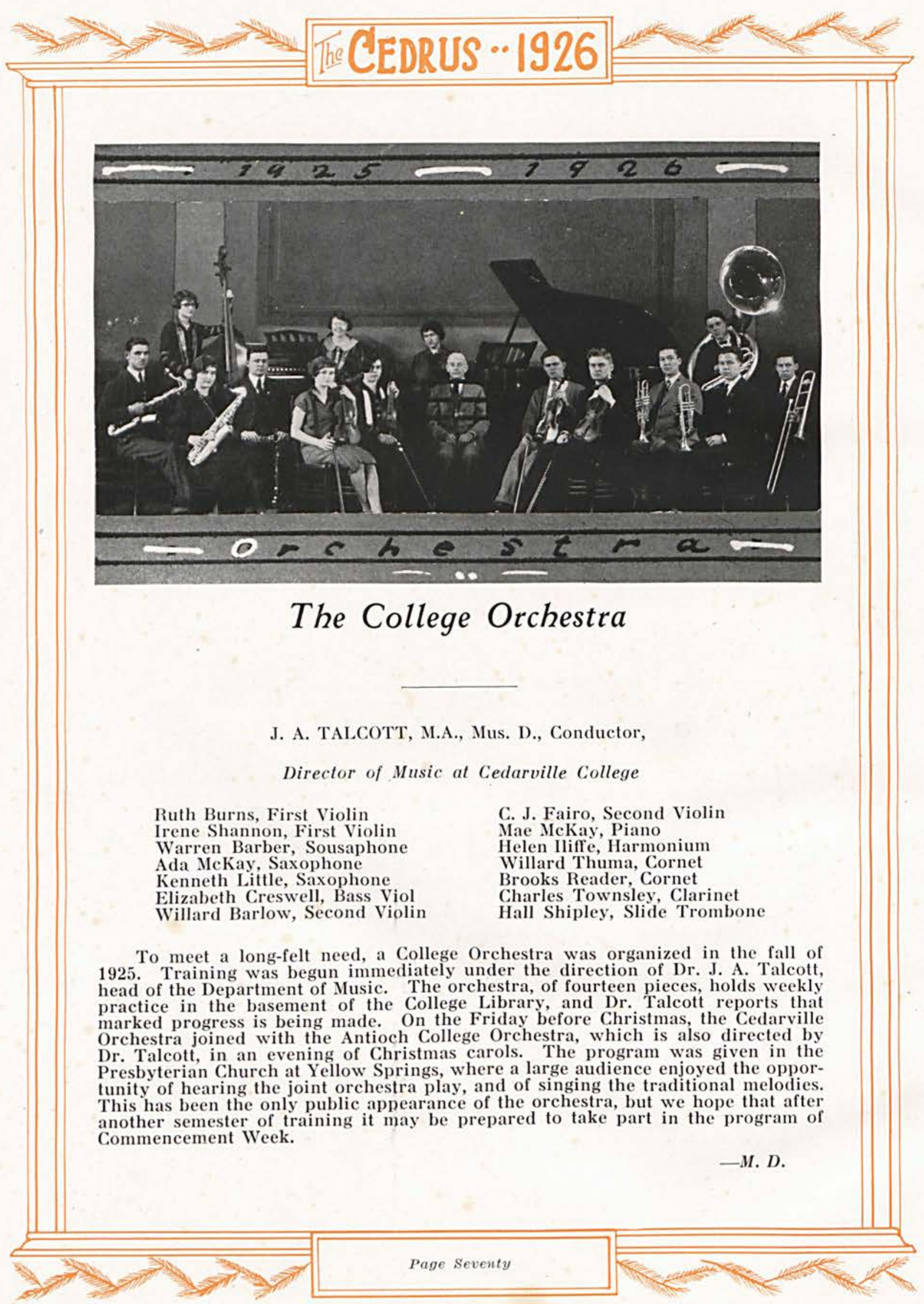




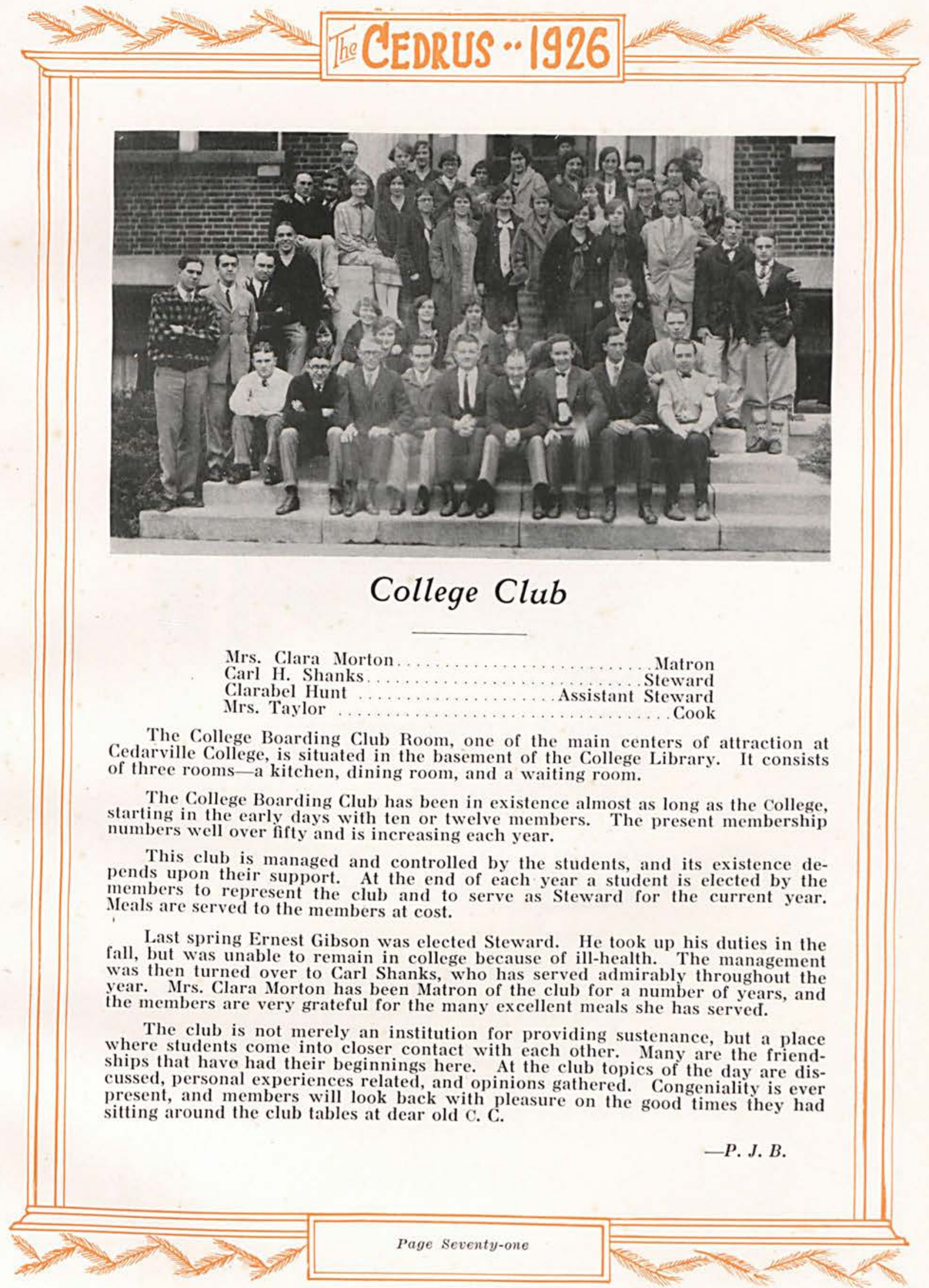




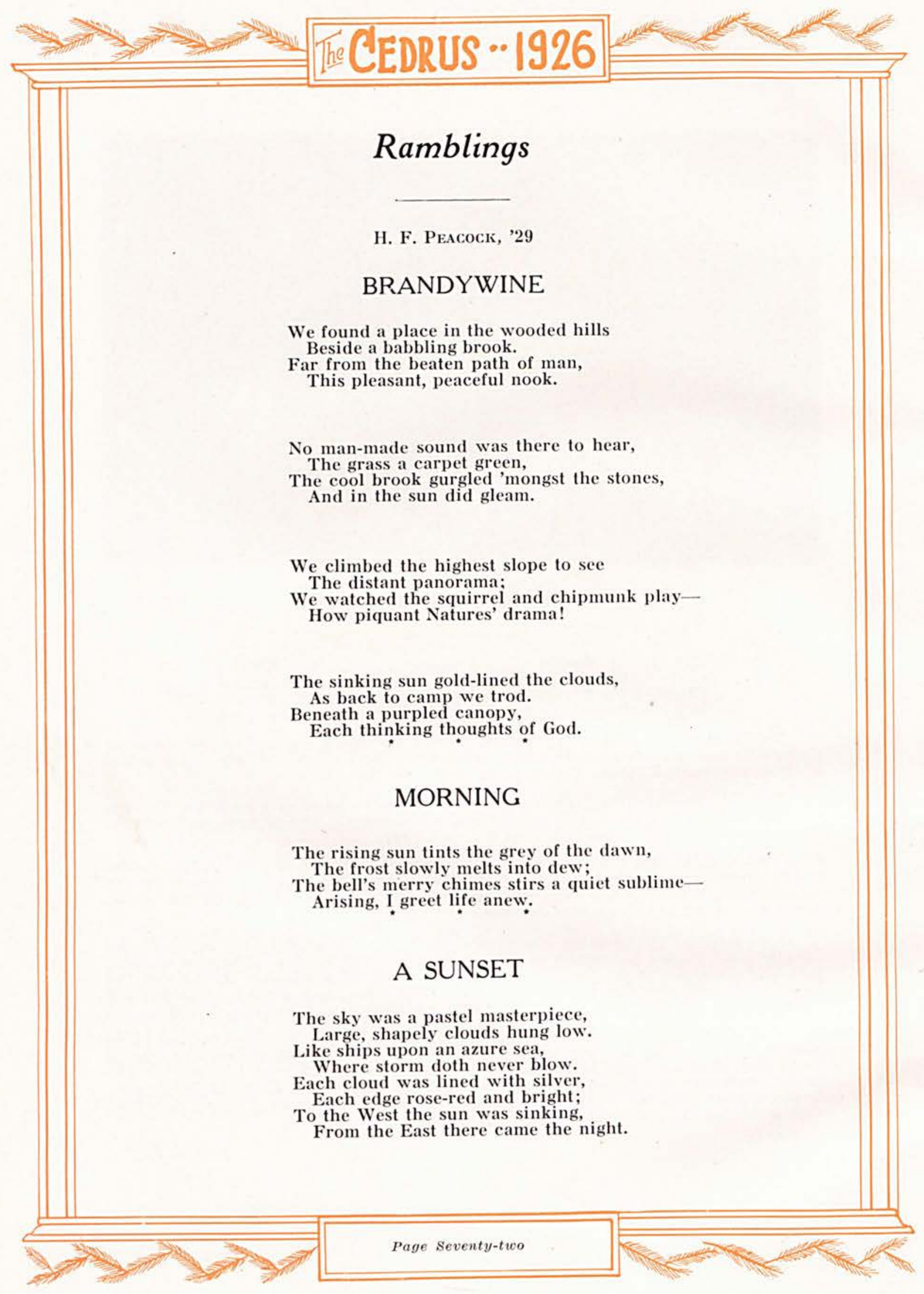




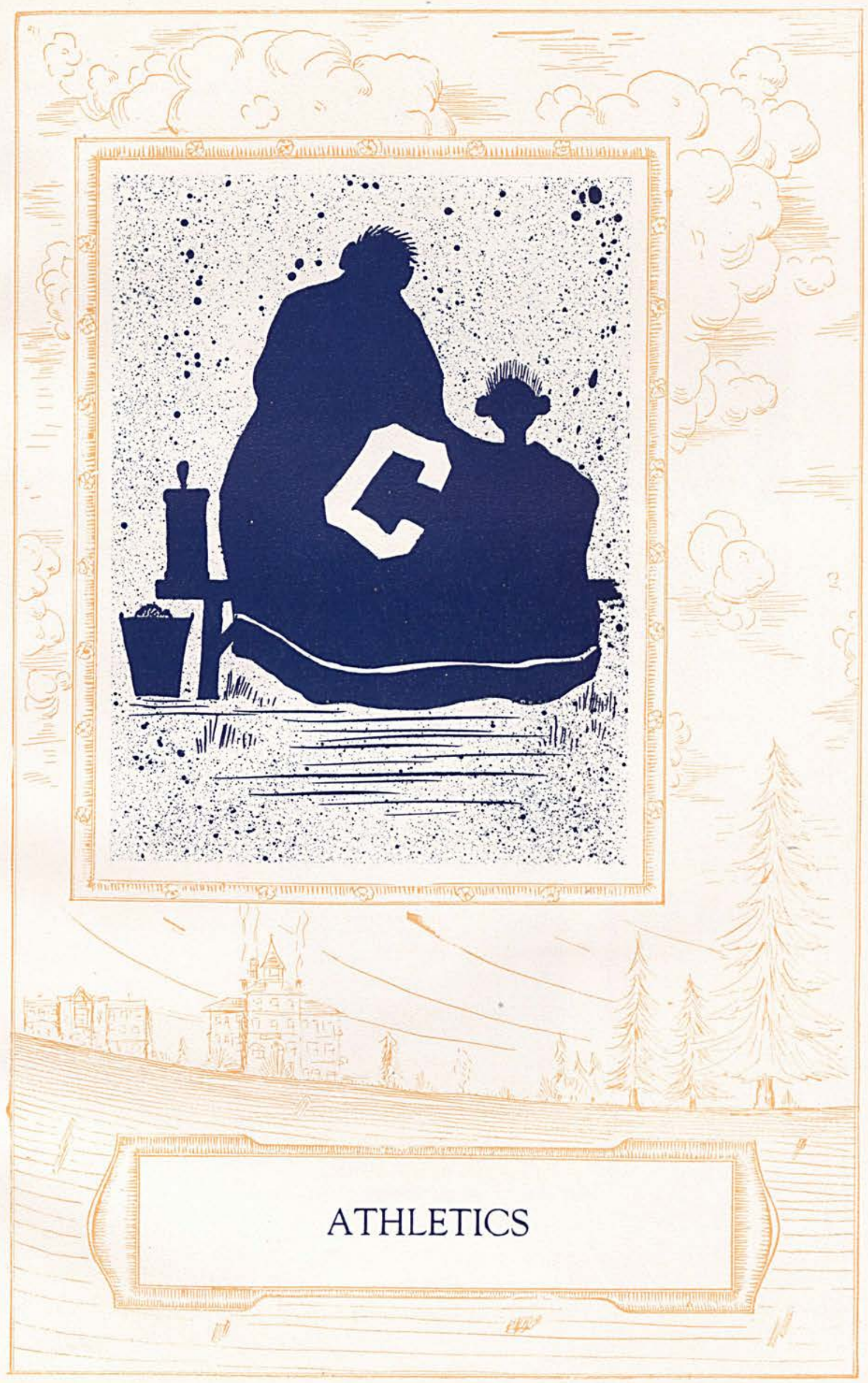




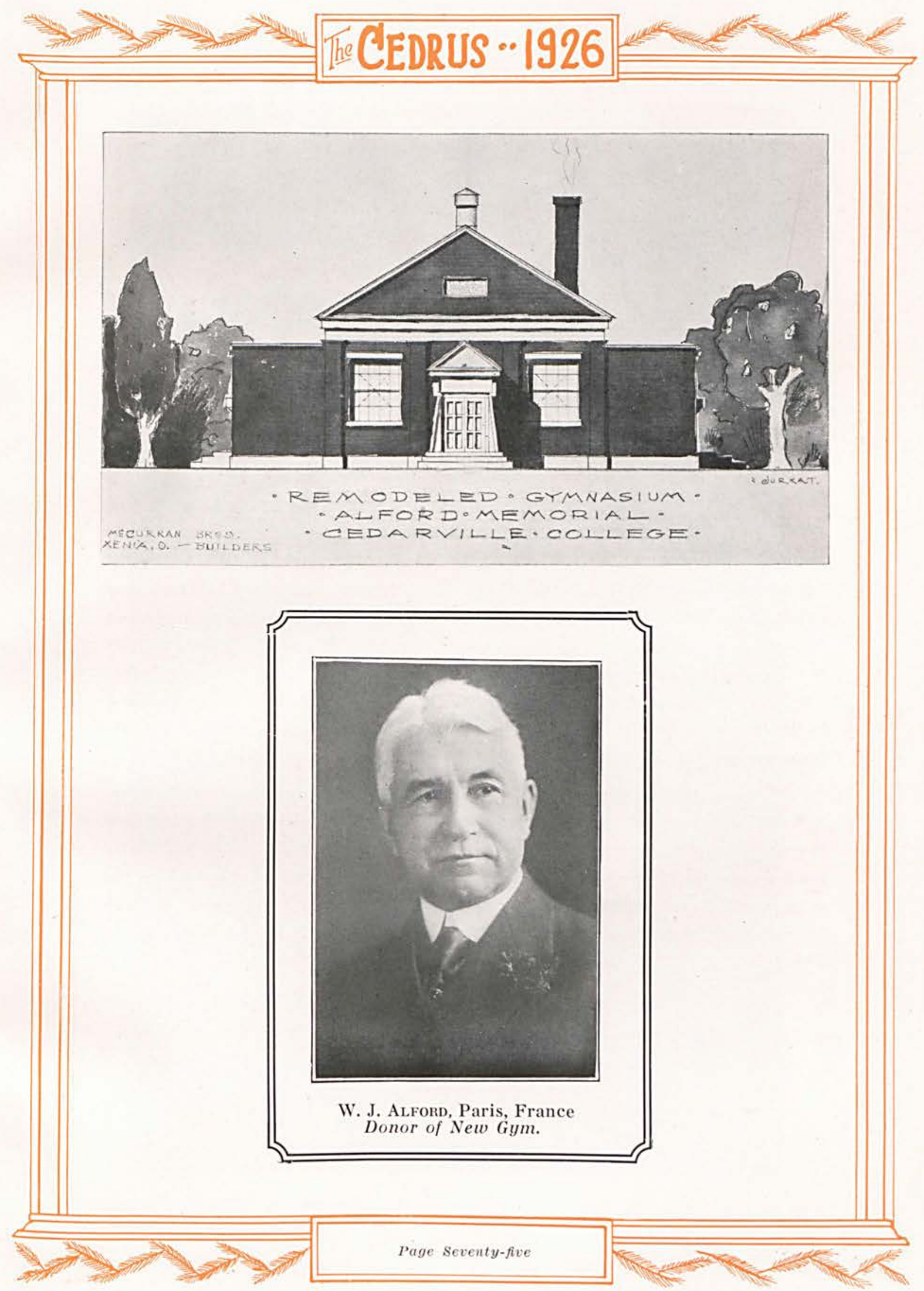




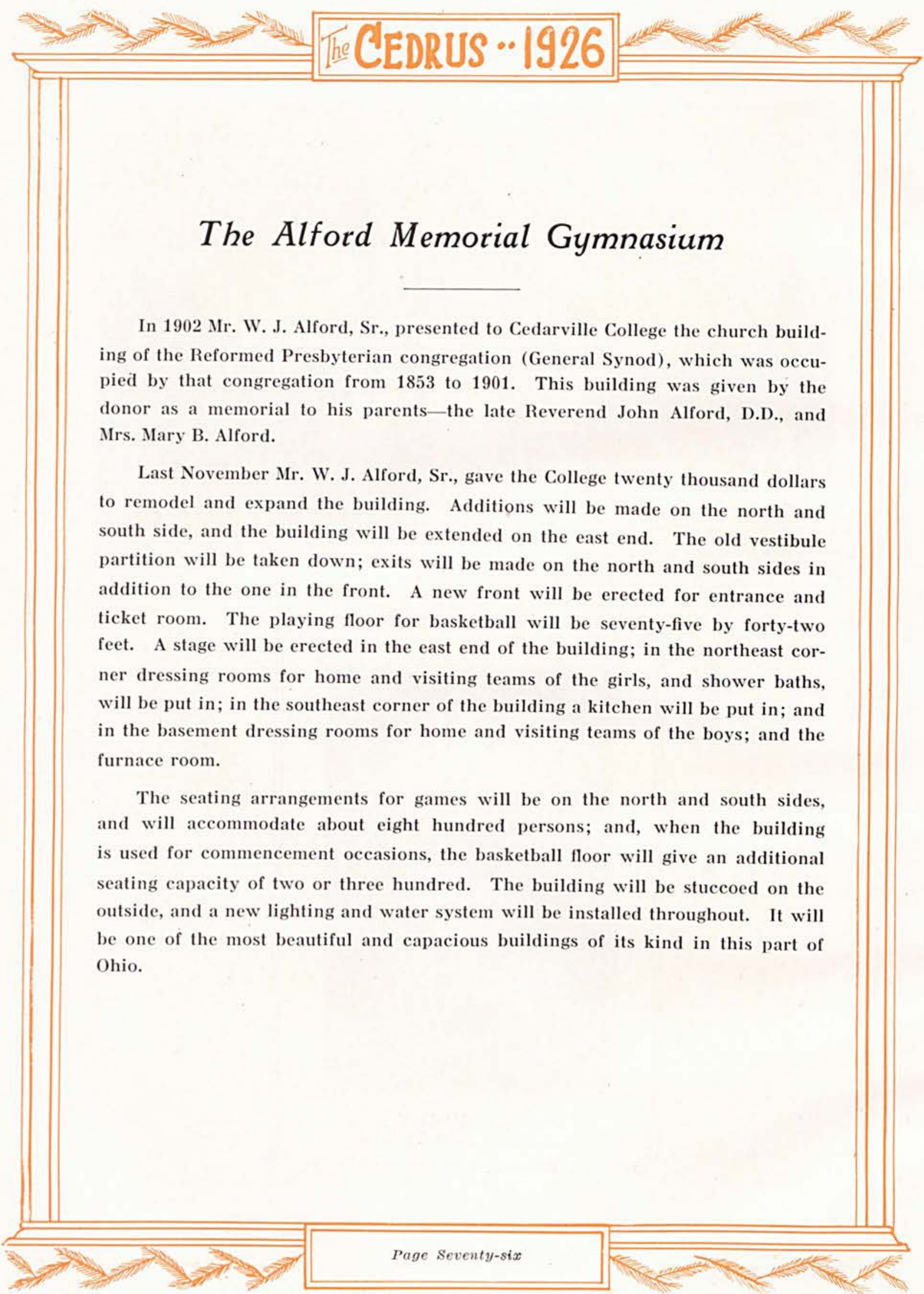




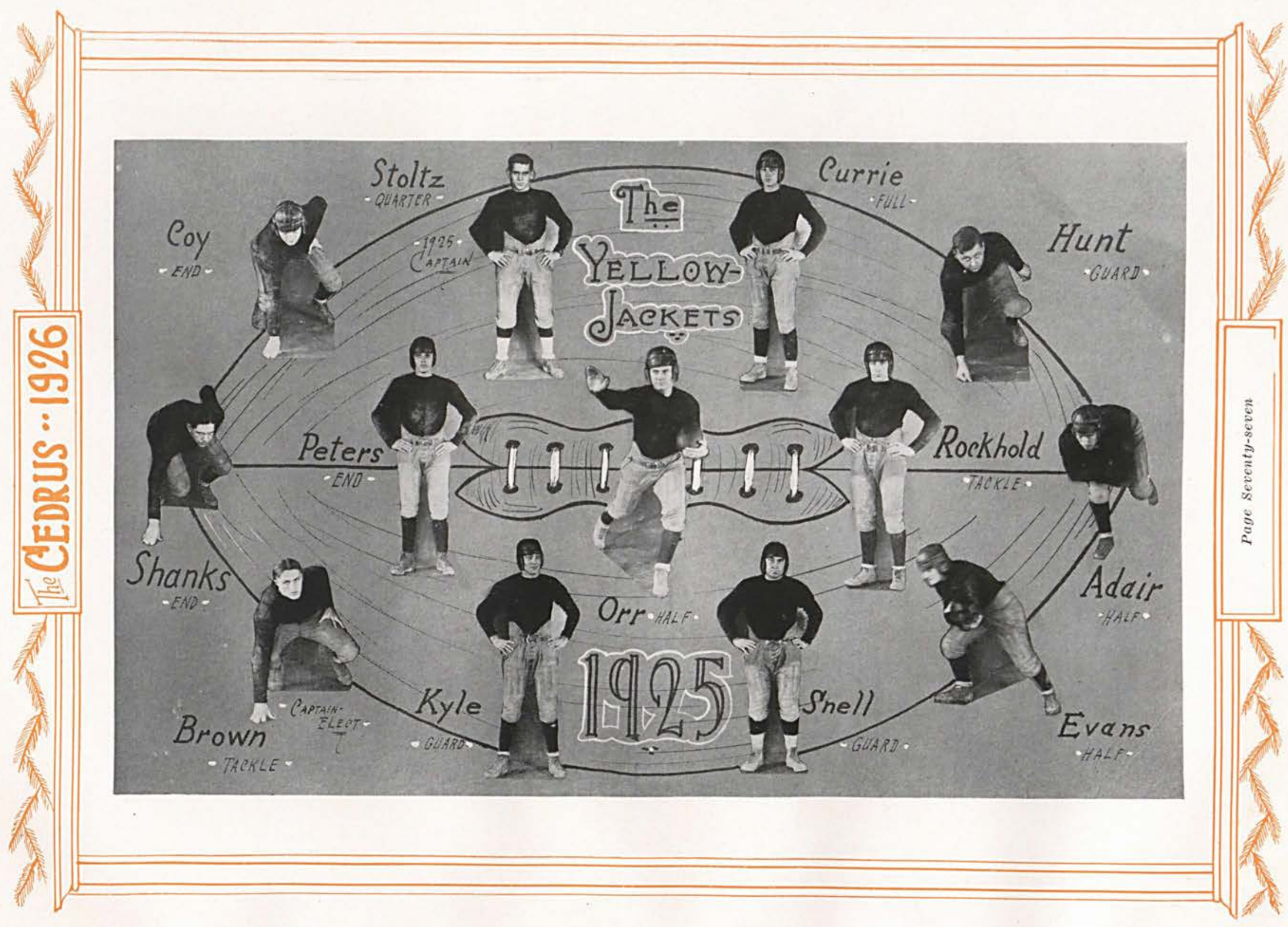




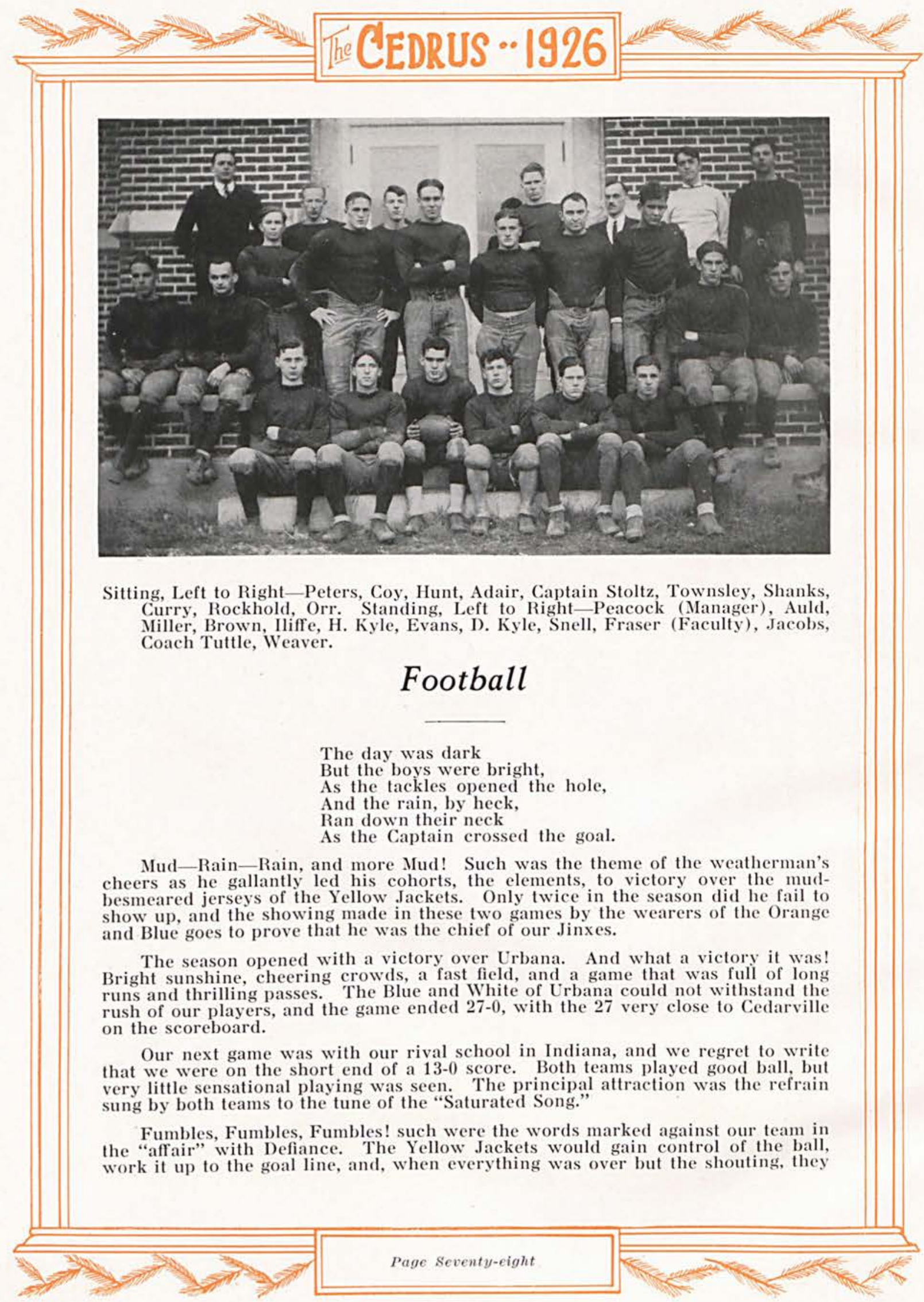




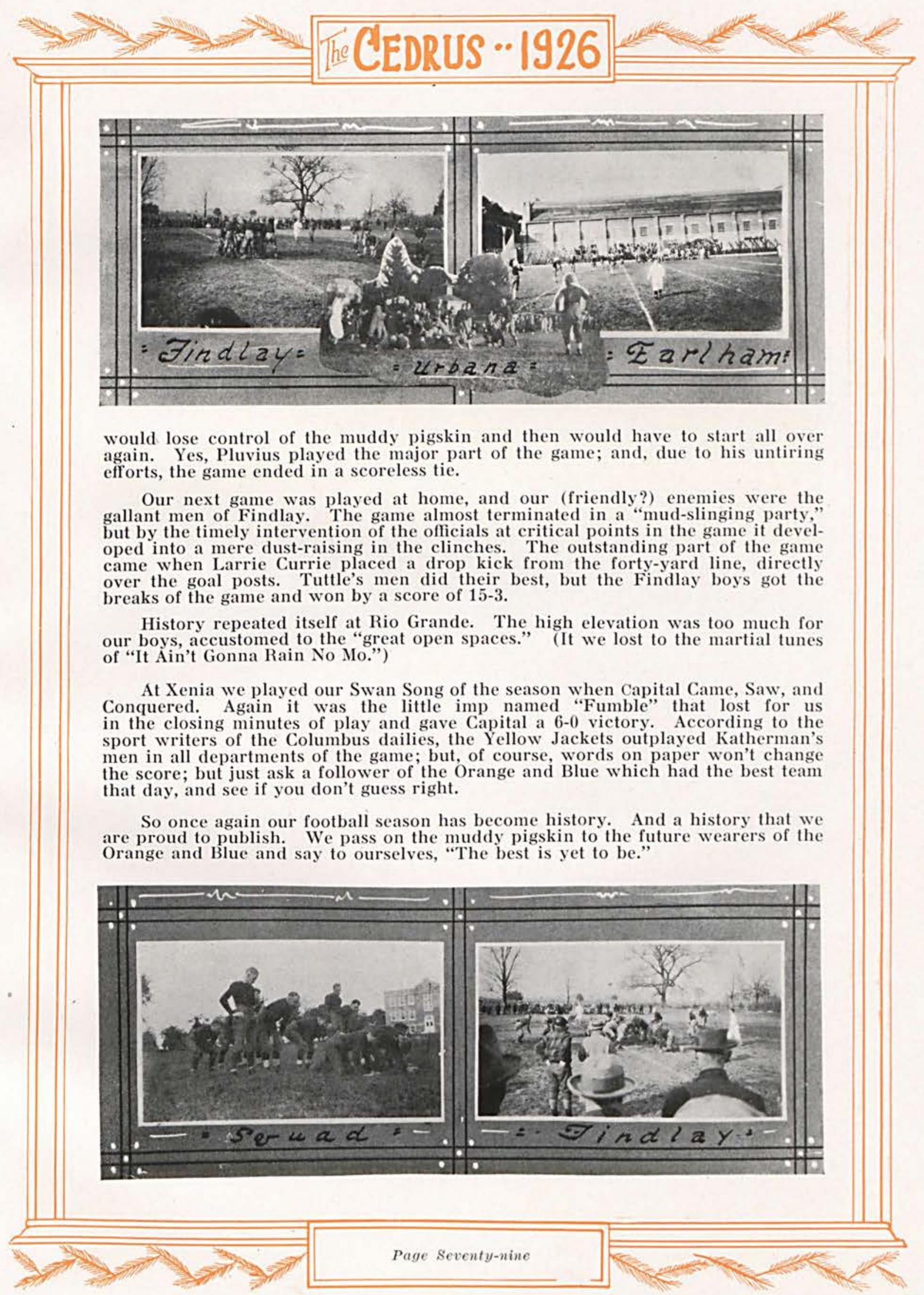




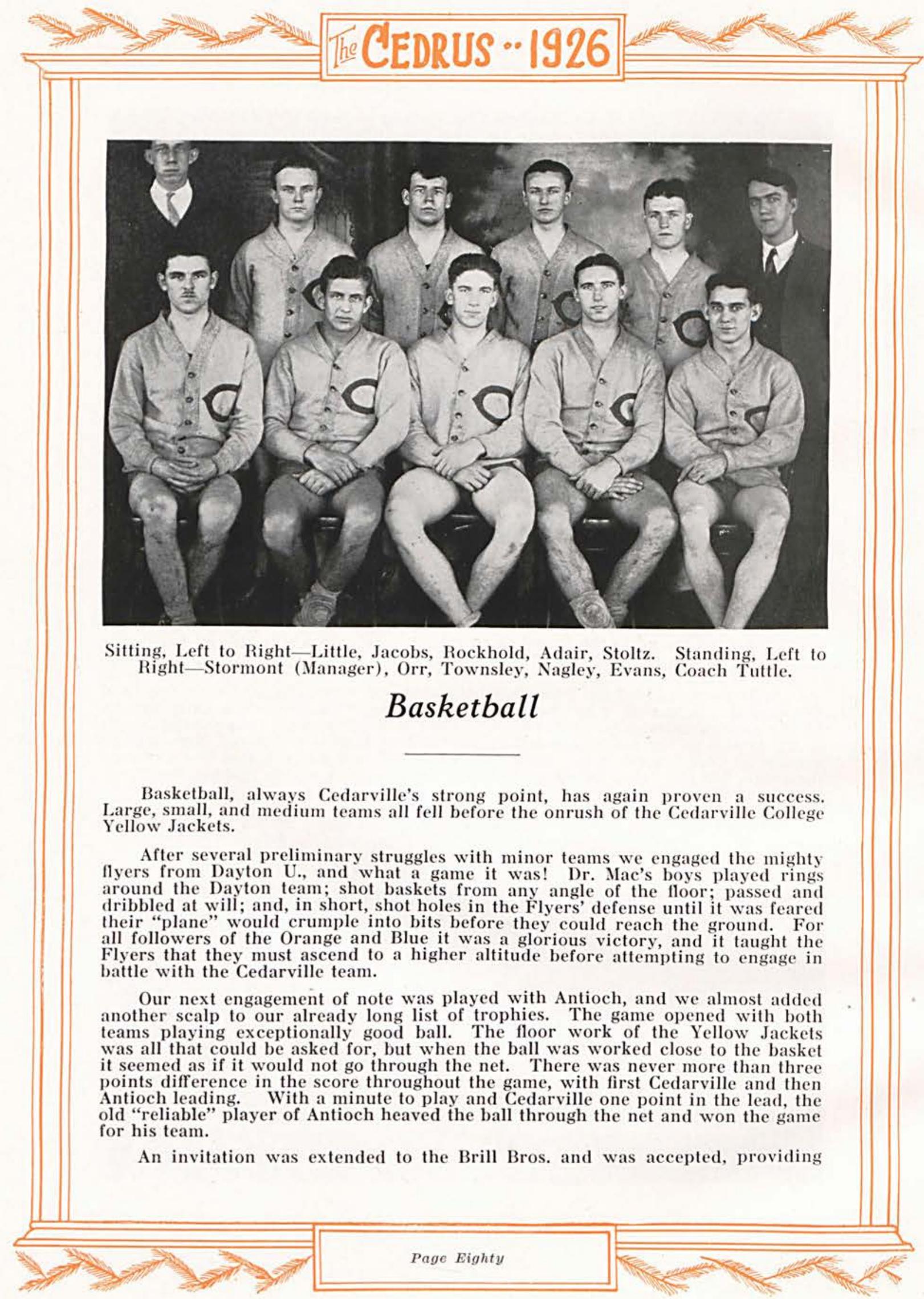




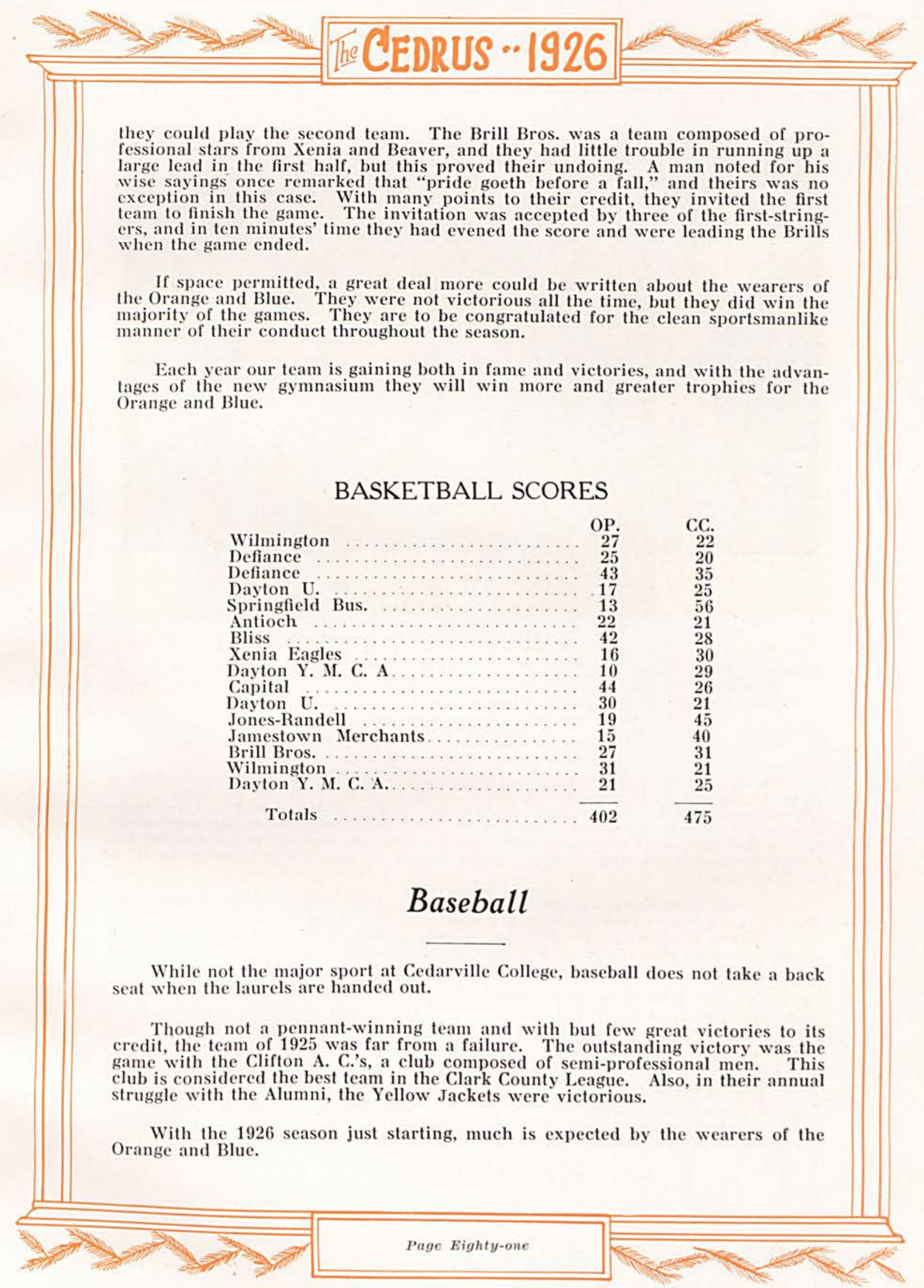




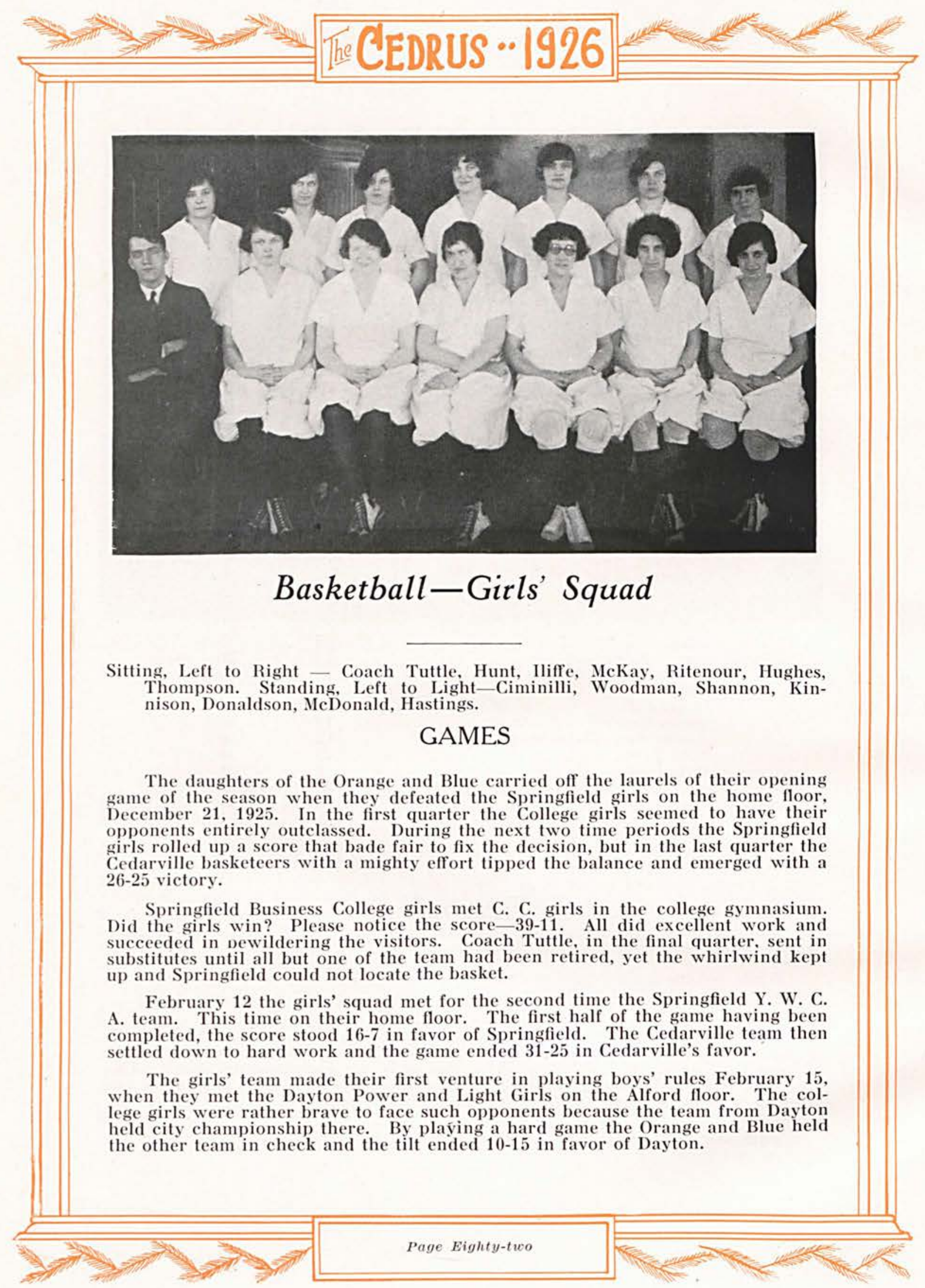




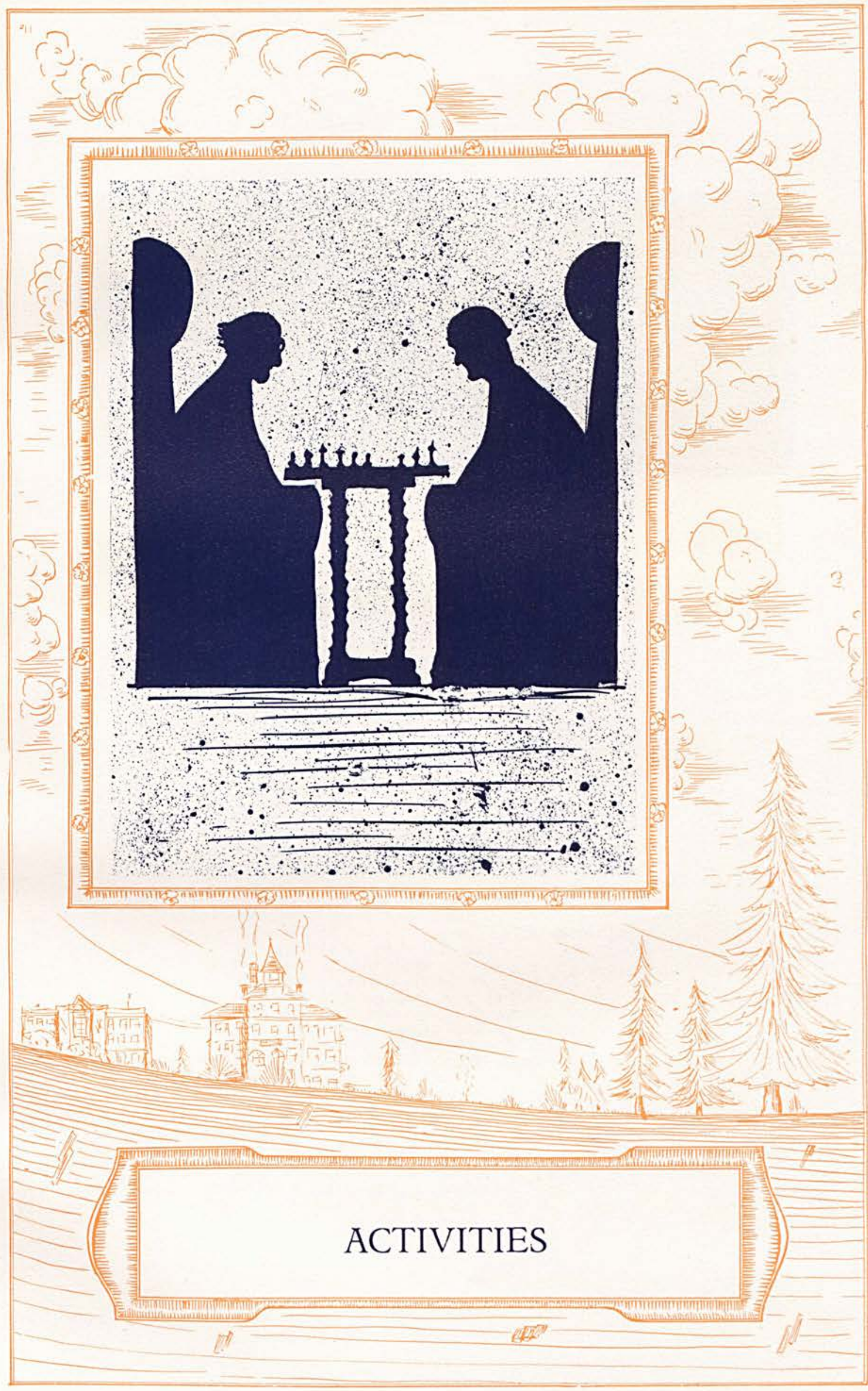





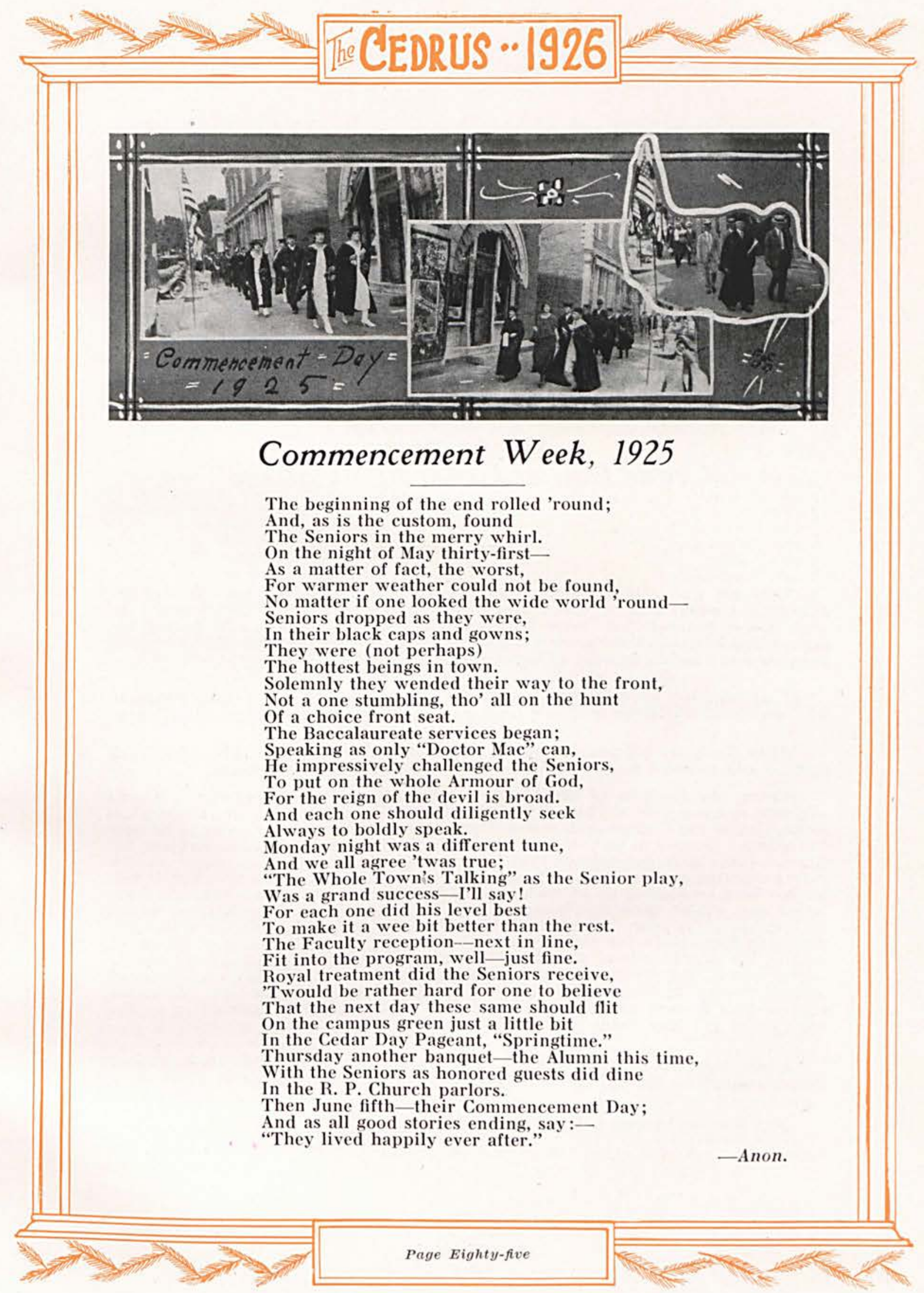




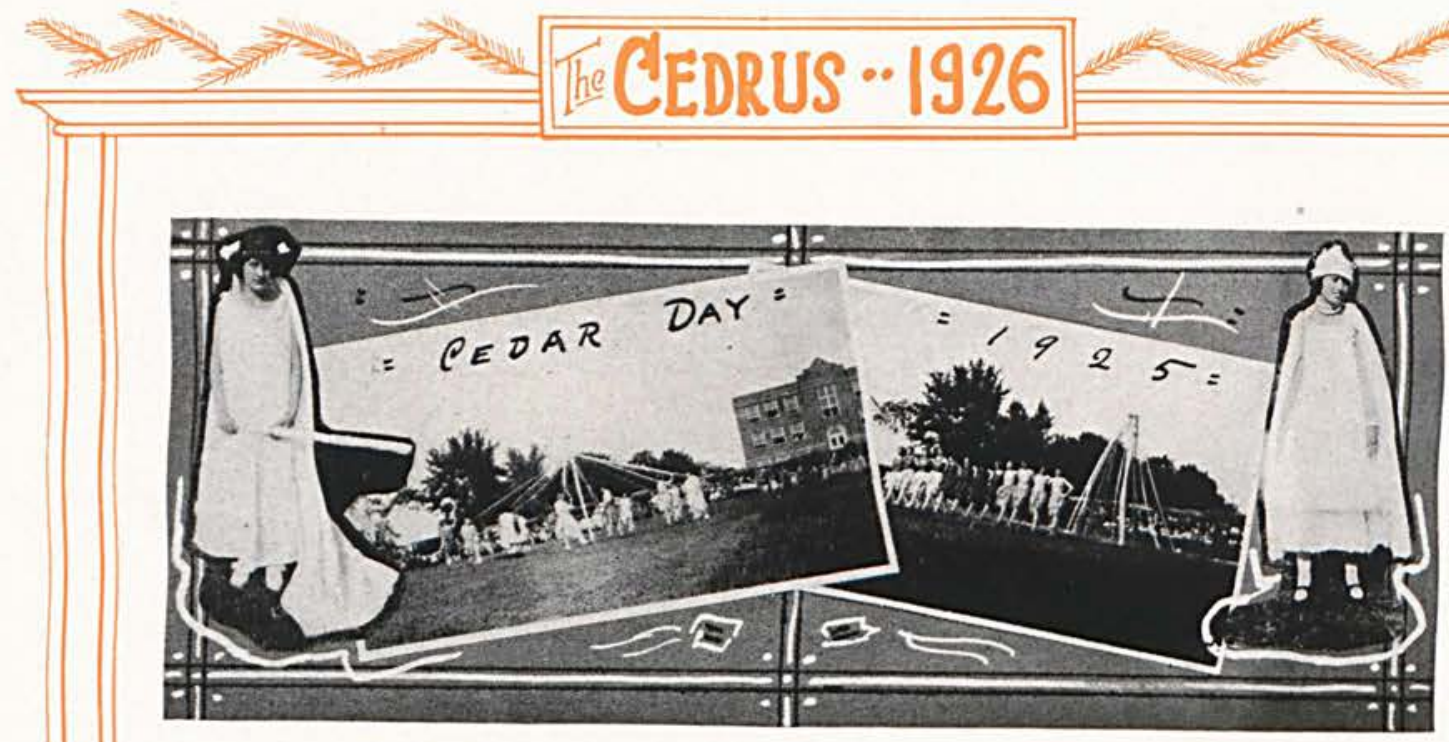

\section{Cedar Day at Cedarville College}

This day was originally observed in the early spring of the year. One of the important features was the planting of a cedar tree some place on the campus. In 1920 it was decided that Cedar Day could not be conveniently held during the school term. It was then given a definite day in Cedar Week, and has ever since been observed on Wednesday of Commencement Week.

Last year we were favored with ideal weather for an out-of-door program. The afternoon was given over to a baseball game between the College and Alumni.

After the game a pageant, entitled "Springtime," was given. This old Greek myth of summer and winter furnished the background for the pageant.

Ceres, the Goddess of the Seasons, has a daughter, Prosperpina. Cupid appears, shoots a dart at Pluto, who is lurking about, and another at Prosperpina. Pluto, God of the Underworld, seizes Prosperpina and carries her away to become his queen. Dances of sorrow and consolation are given by Grecian maidens for Ceres. Ceres will not believe that her daughter is gone until a water nymph enters carrying a green scarf of Prosperpina's. Ceres then believes that her daughter has been swallowed up by the earth, and in anger pronounces a curse of desolation and winter upon it. Winter, North Wind and Snow Ball choruses depict this period of the year. A messenger from the Gods enters and tells Ceres that her daughter may return for six months of each year. Ceres then alters her curse, making six months winter and the remaining six summer. Summer immediately begins with a long, joyous procession bearing Prosperpina. She is declared Queen and is crowned by Ceres as Goddess of Spring or Queen of Cedar Day. Choruses representing flowers and sunshine dance before their Queen, concluding in the winding of the May Pole.

Cedar Day at Cedarville College is a day of reunion; and an old-fashioned, quaint holiday for the College, town, and community.

May it never become a day of the past. - A. O.

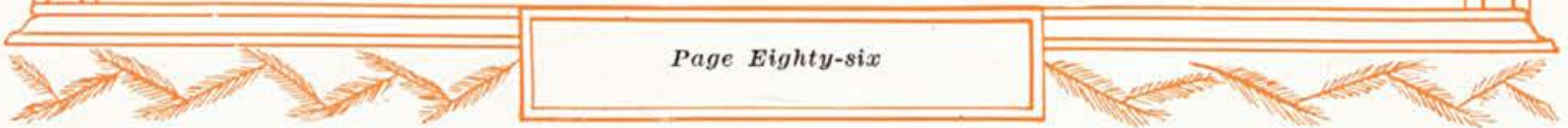




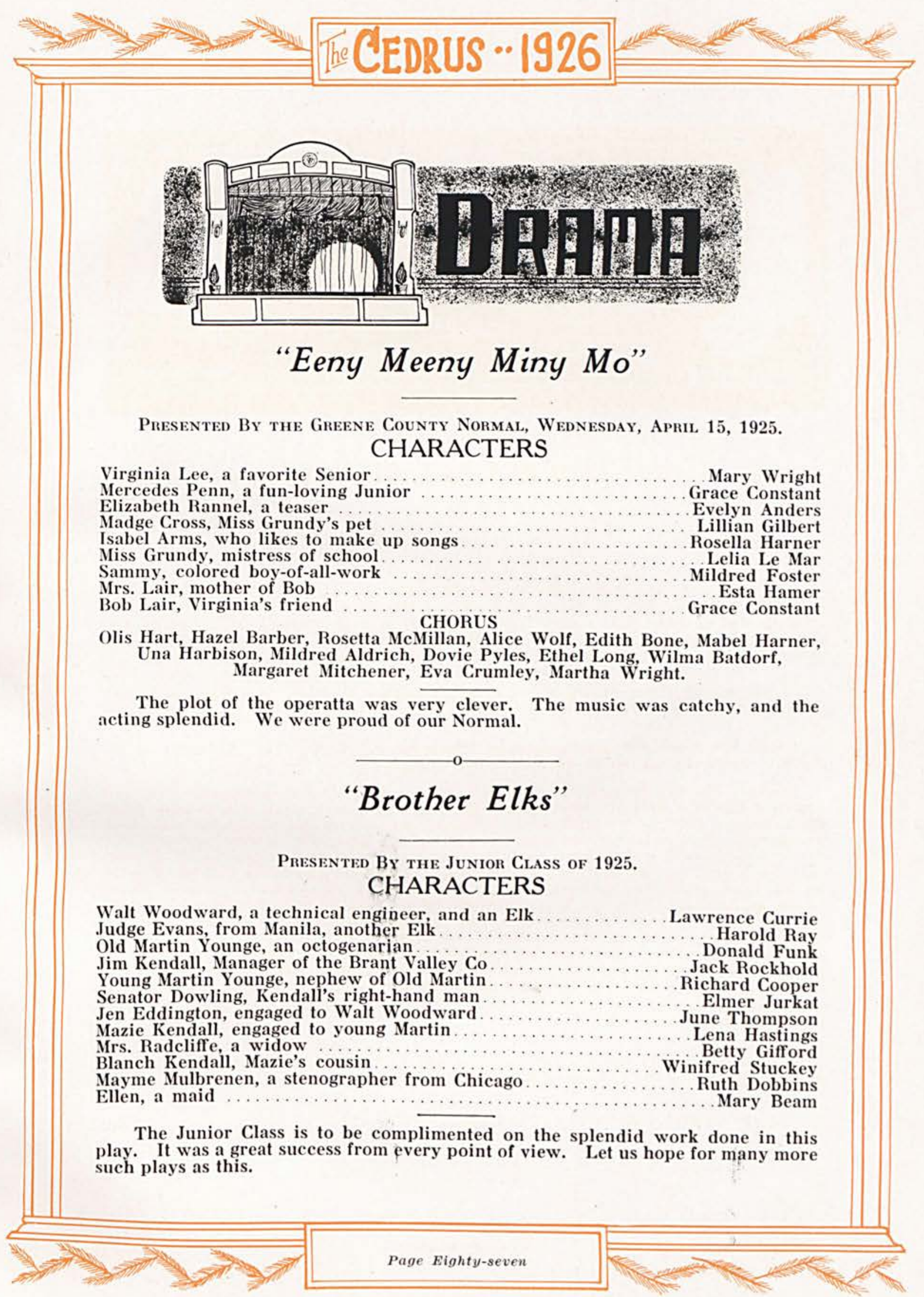




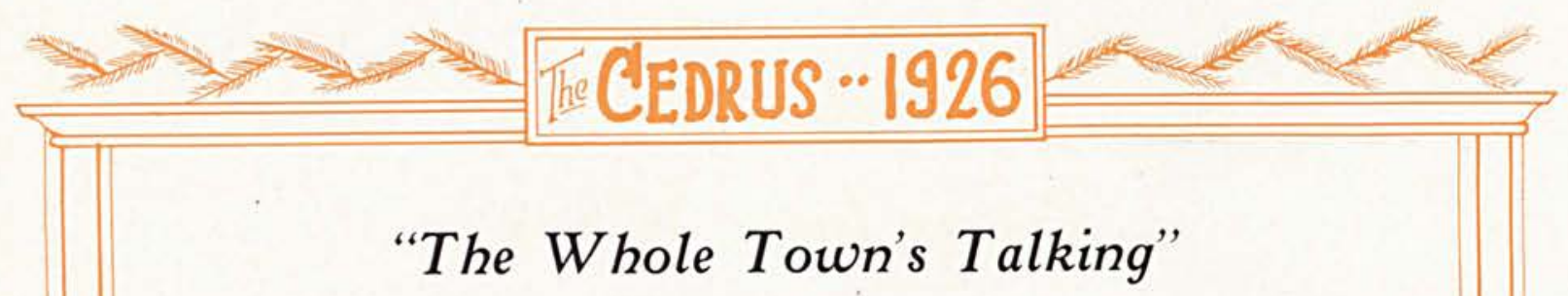

Presented By the Senion Class of Cedarville College, Monday, June 1, 1925. CHARACTERS

Henry Simmons, a manufacturer

Harriet Simmons, his wife

Ethel Simmons, their daughter

Chester Binney, Simmons' partner

Letty Lythe, a motion picture star

Donald Swift, a motion picture director

Roger Shields, a young Chicago blood

Lila Wilson Friends of ?

Sally Otis... Fthel

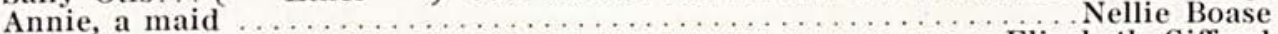

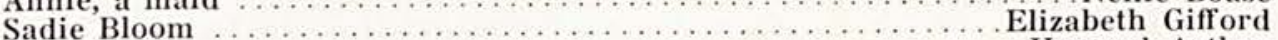

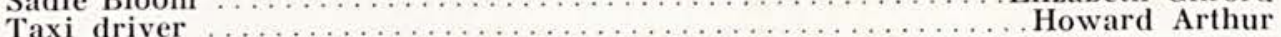

The Seniors were very wise in choosing such a play as this for their last appearance in a public performance at Cedarville College. The play was the first event of Commencement Week, and started it off with much pep and enthusiasm.

\section{"The Lion and the Mouse"}

Presented By the Junior Class, Wednesday, January 20, 1926.

\section{Characters in Order of Their Appearance}

Eudoxia

Rev. Pontifex Deetle

Lois Manor

Rev. Pontifex
Jane Deetle

Harold Huston

Mrs. Rossmore

Miss Nesbit

corena Sharpe

Judge Rossmore

Mae McKay

Ex-Judge Stott

Isabel Clarke

Expressman

Carl Shanks

Jefferson Ryder

Hon. Fitzroy Bagle

ard Creswell

Jorkins

William Snell

Mary Townsley

Willard Barlow

Malcolm Turner

Senator Roberts

Kate Roberts

John Rockhold

Mrs. John Burkett Ryder

Ruth Burbick

John Burkett Ryder

obert Turnbull

Maid

Mary Beam

The play, "The Lion and the Mouse," was decided upon this year as the annual Junior play. The play was a success, due to the careful study of the cast and the skillful directorship of Miss Susan M. Koehlar.

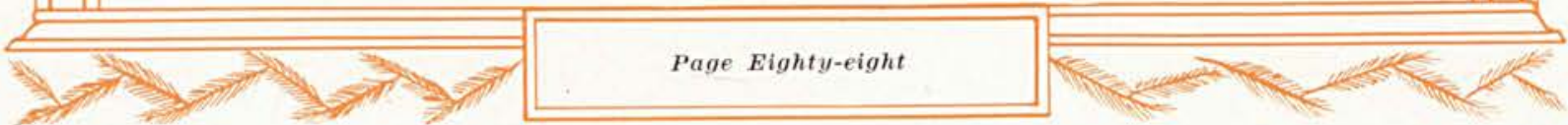




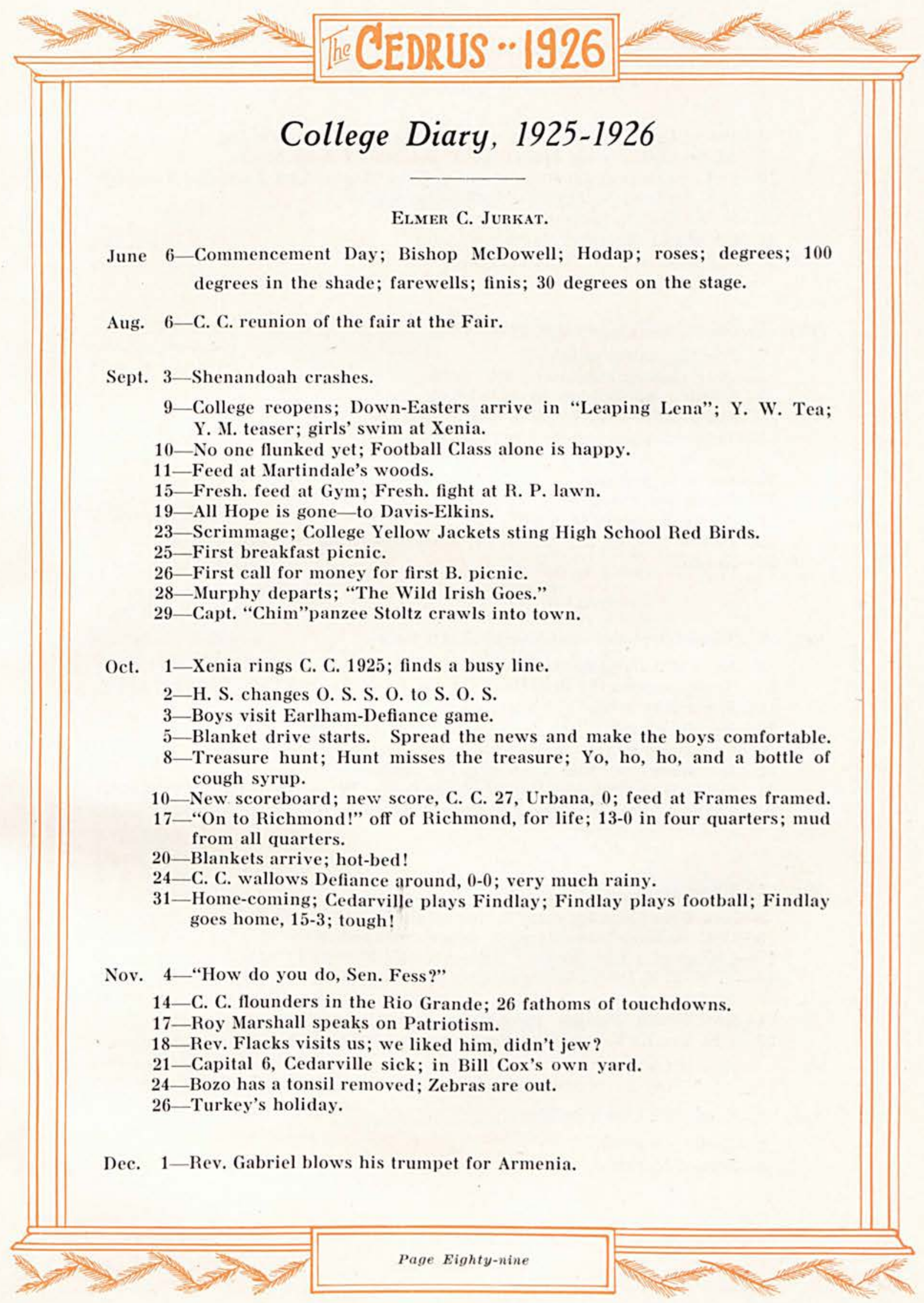




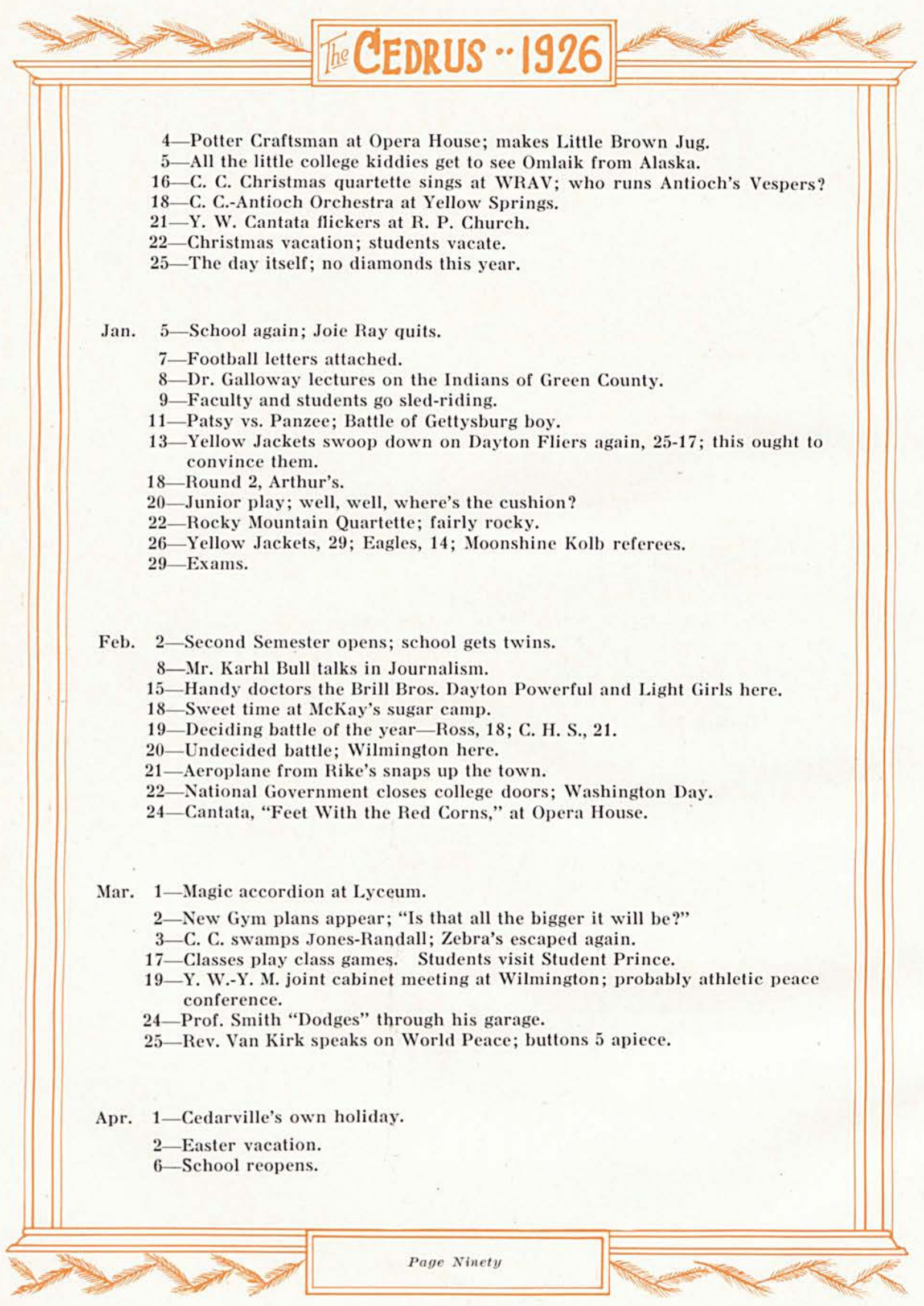




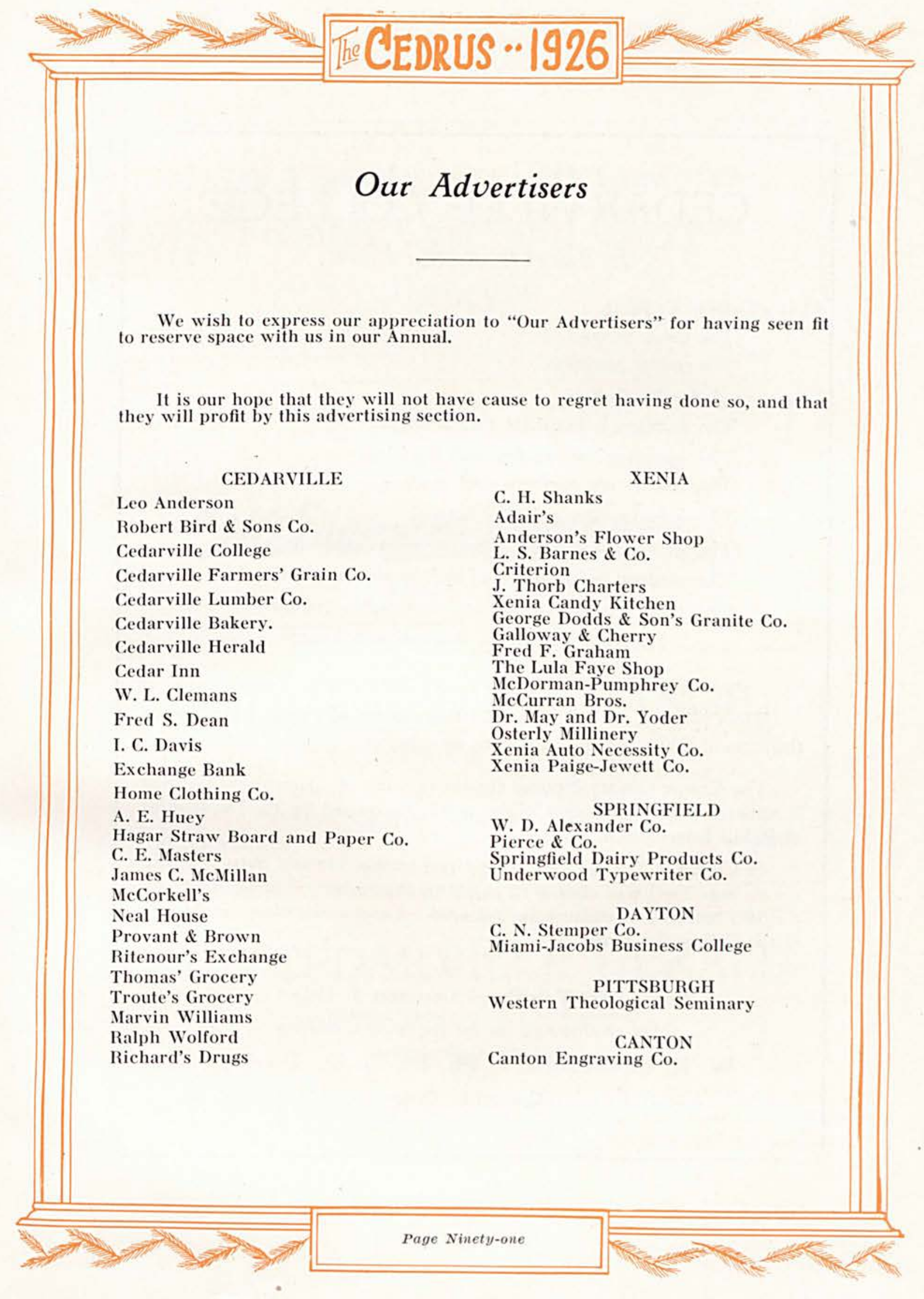




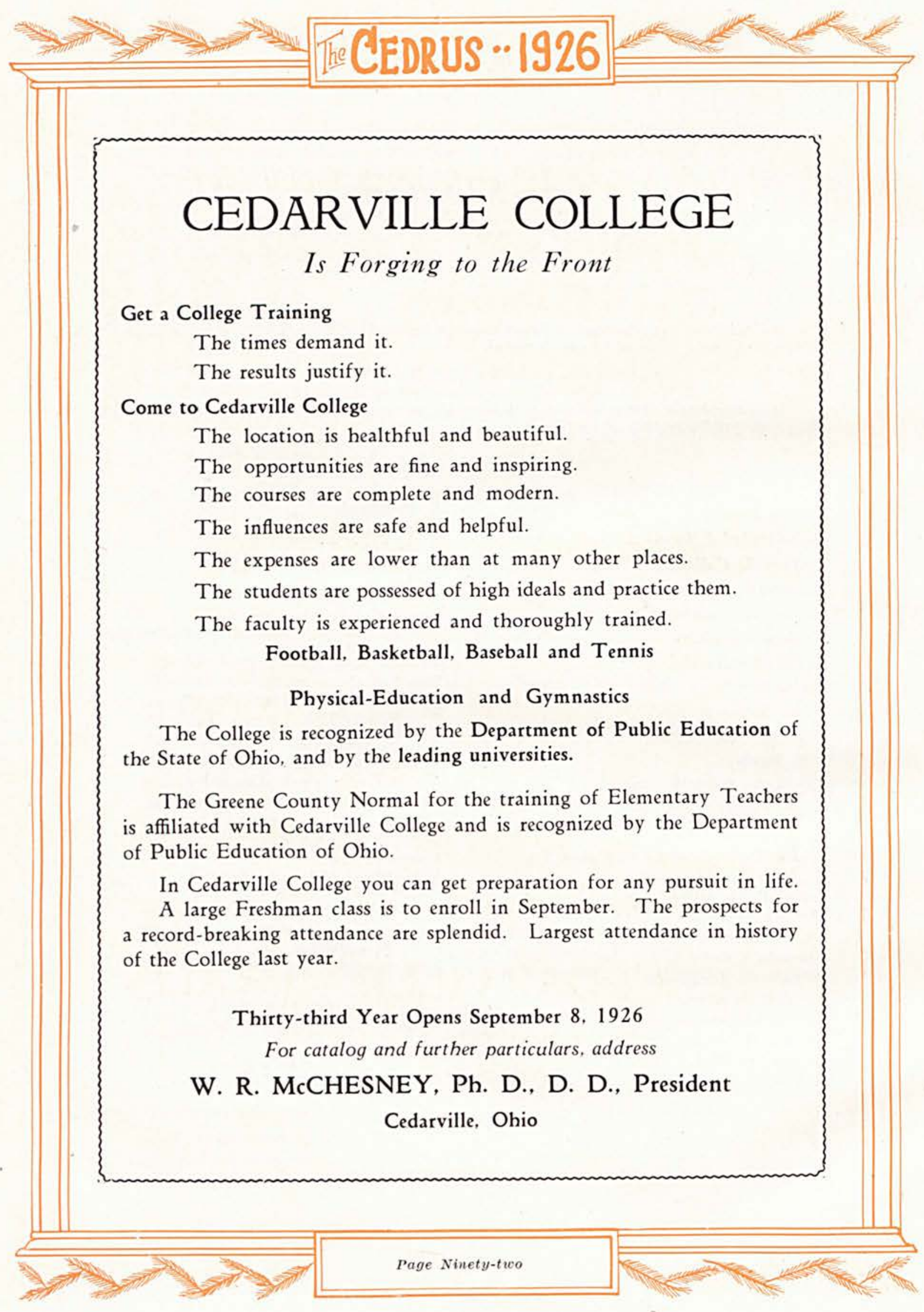




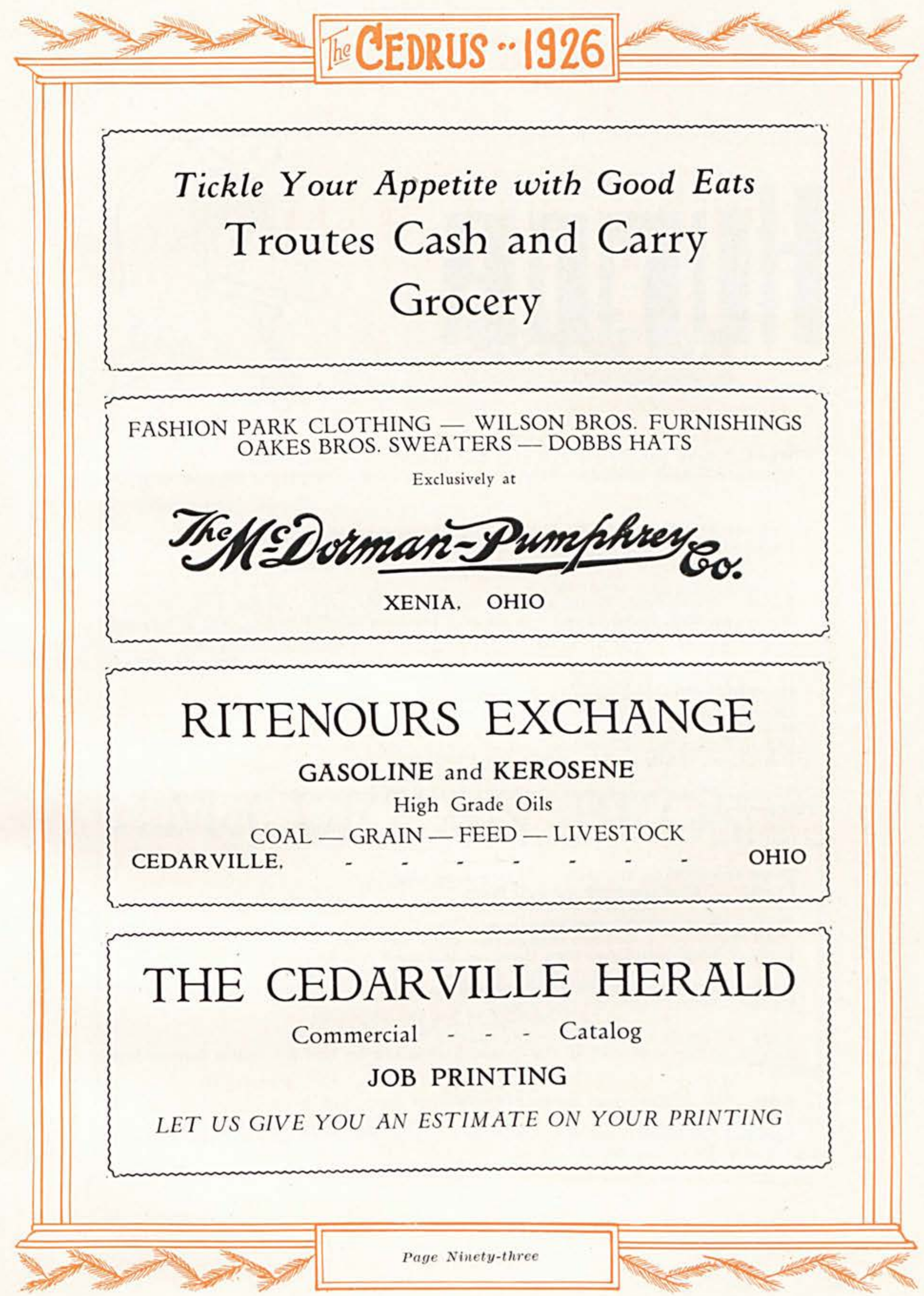




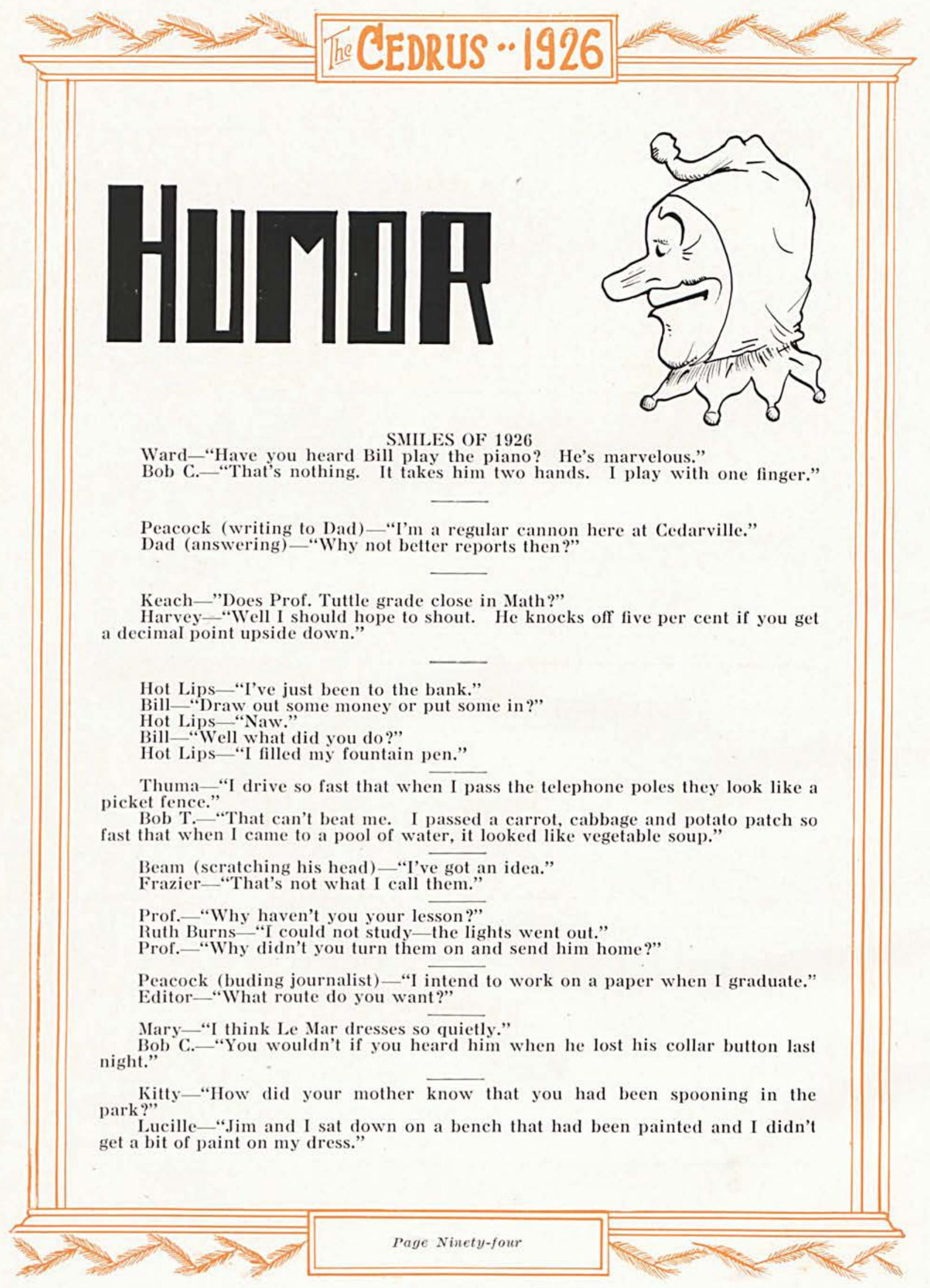




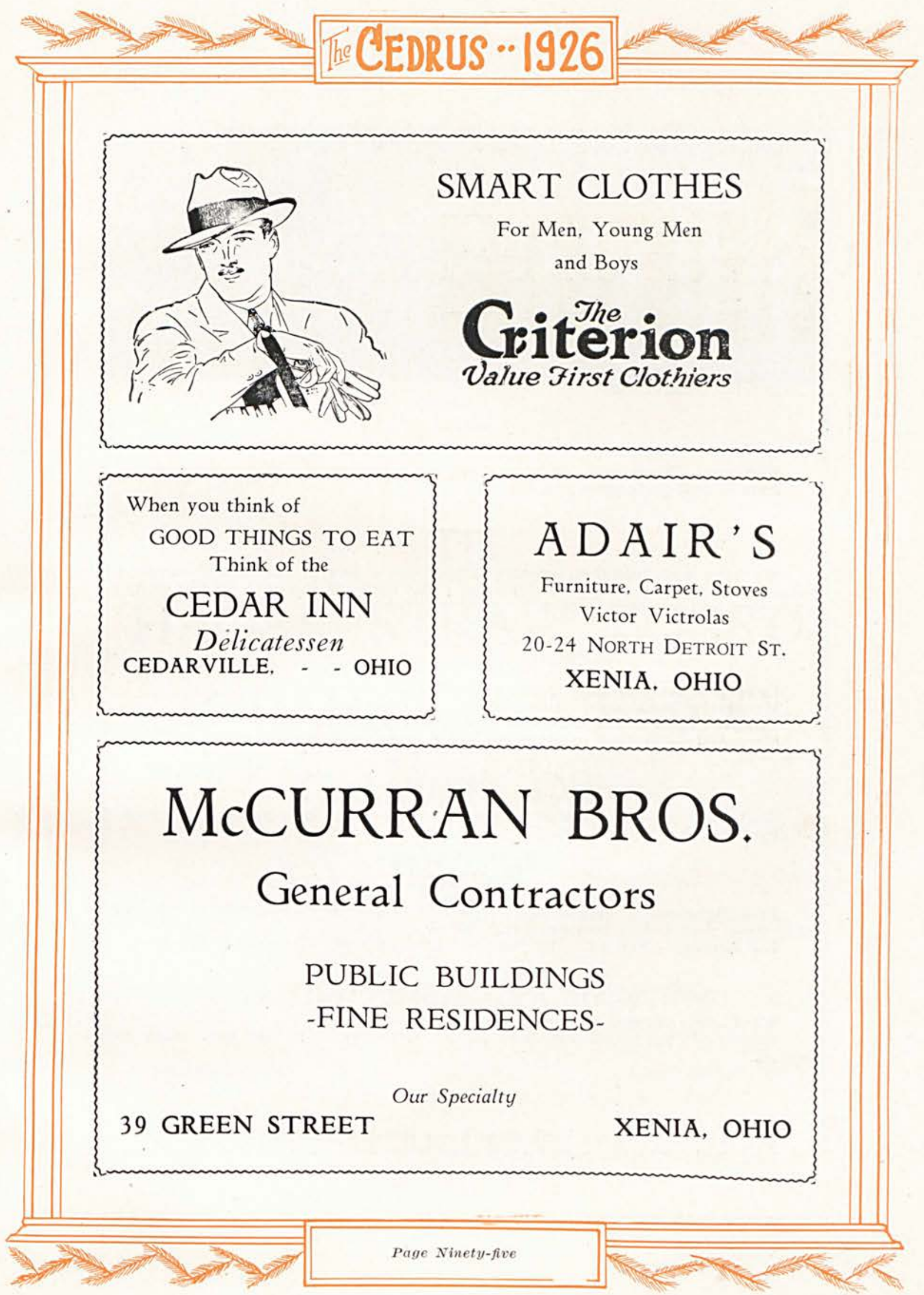




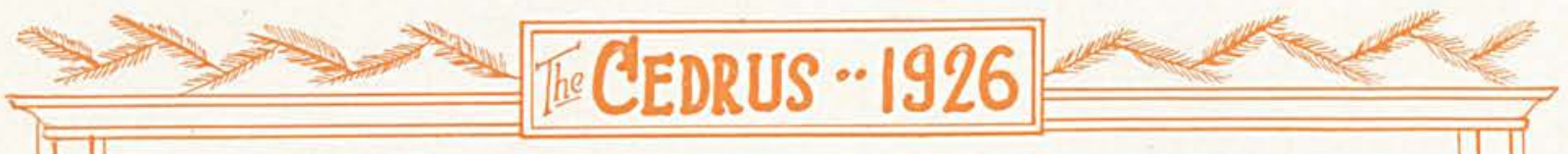

"Father-"What did you do with that last ten dollars I gave you?"

Cutie- "I bought a dollar's worth of oranges and apples and spent the rest on dates."

Customer-"Waiter, there is a rock in this ice-cream.",

Jack Rockhold-"What do you want, the whole brick?"

Ethel-"I can hardly wait until Wednesday on account of gym."

Gladys-"Jim who?"

Ethel-“Gymnasium."

Williams_-"Some men are born great, some achieve greatness, and some__" June-“Just grate upon you."

We have been told that recently "Cutie" left a note on the door for Jack, his room-mate, who had gone to the movies. This bore the legend: "If I'm studying when you get back, wake me up."

Lena- "What town do you come from?"

Marguerite Donaldson-“Rootstown."

Lena-"Funny I never heard of it. What is the population?"

Marguerite- "Do you mean when I'm at home or when I'm at school?"

Student- "Did any member of your family ever make a brilliant marriage?" Prof. Smith-"My wife did."

Prof. Robison - "I believe that you might talk more intelligently if you had a little more sleep before coming to this class."

Bill Barlow-"Yes, sir. But you see I have only one class before this one."

Sibyl- "My parents came over on the Mayflower." landed."

Lorena-"That's nothing; they stayed with my folks the first night they

Bob Jacobs-"You say Yank plays a one-stringed instrument in church?" Don Funk- "Yes, he pulls the bell rope."

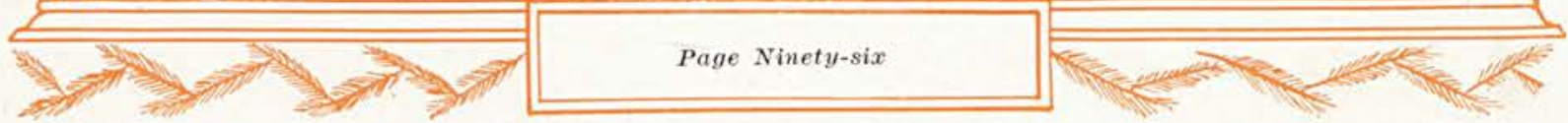





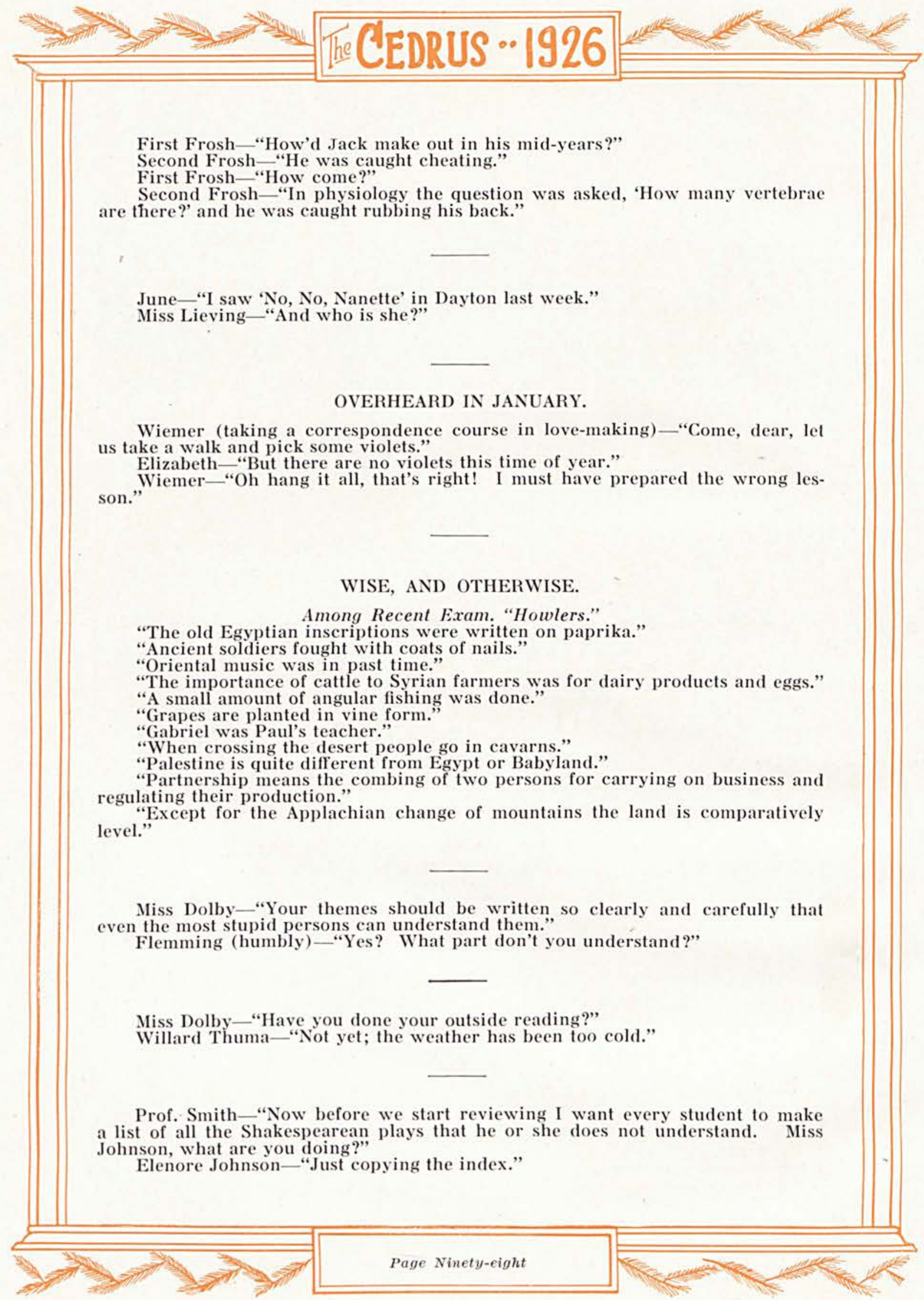




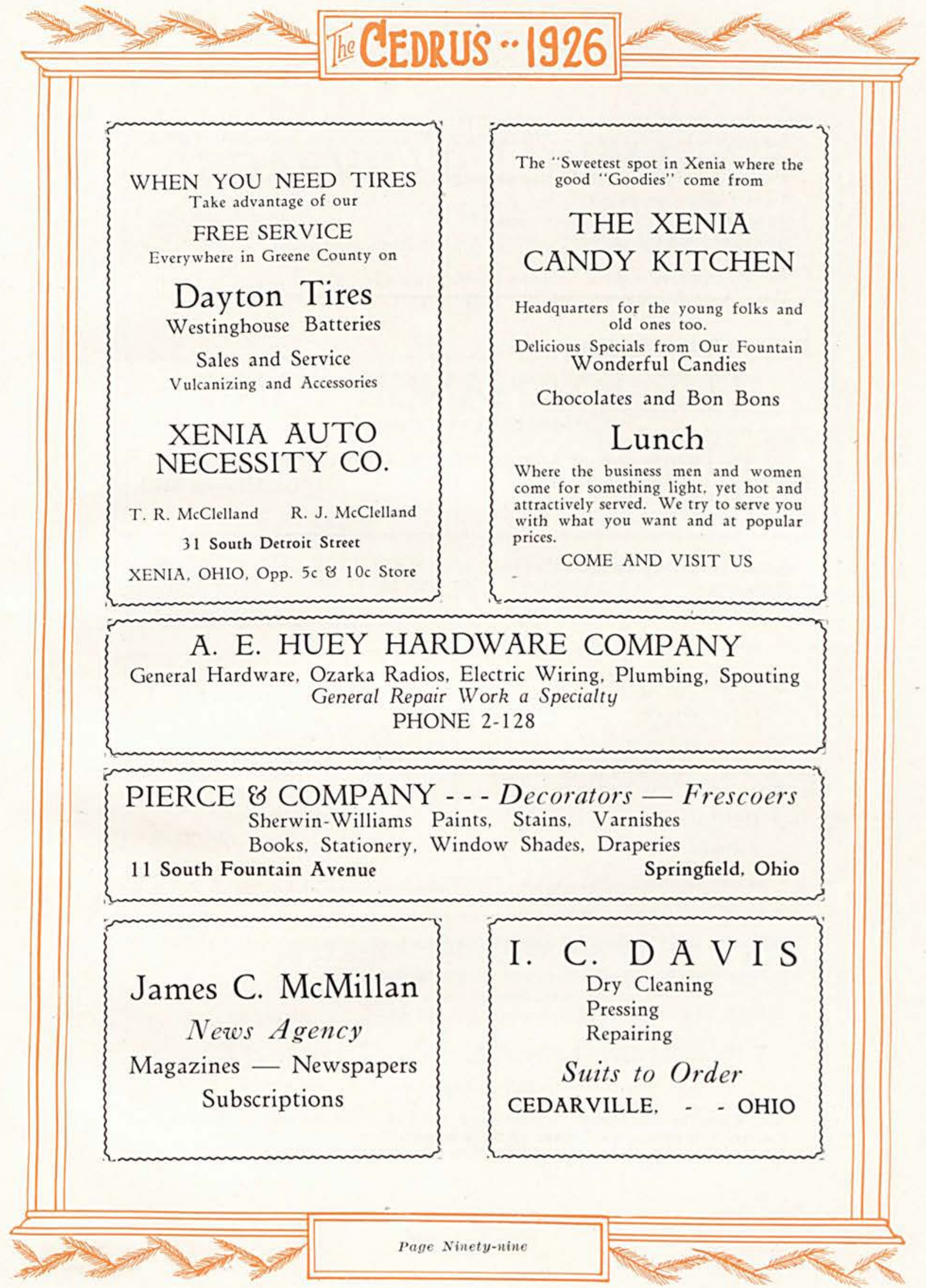




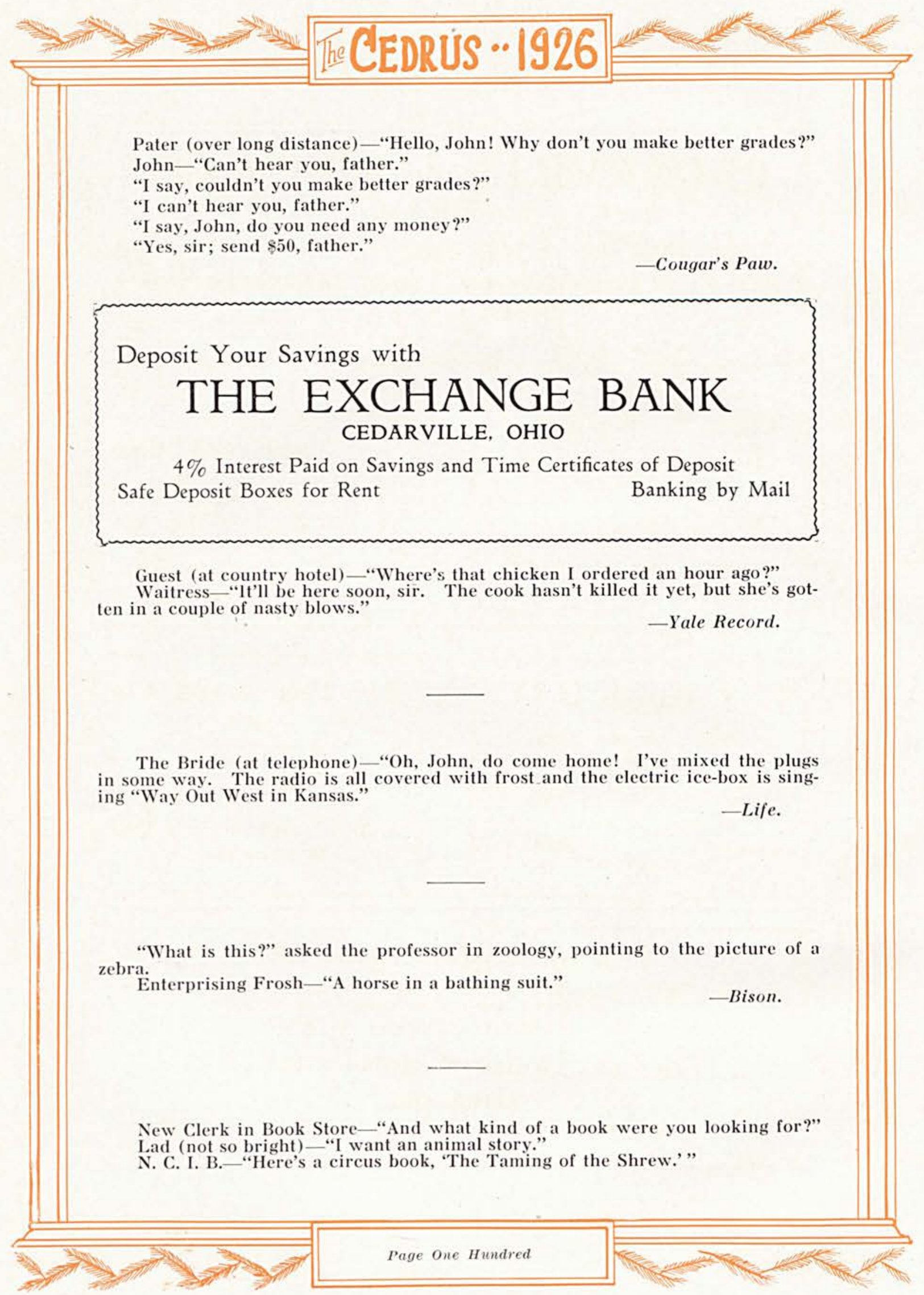




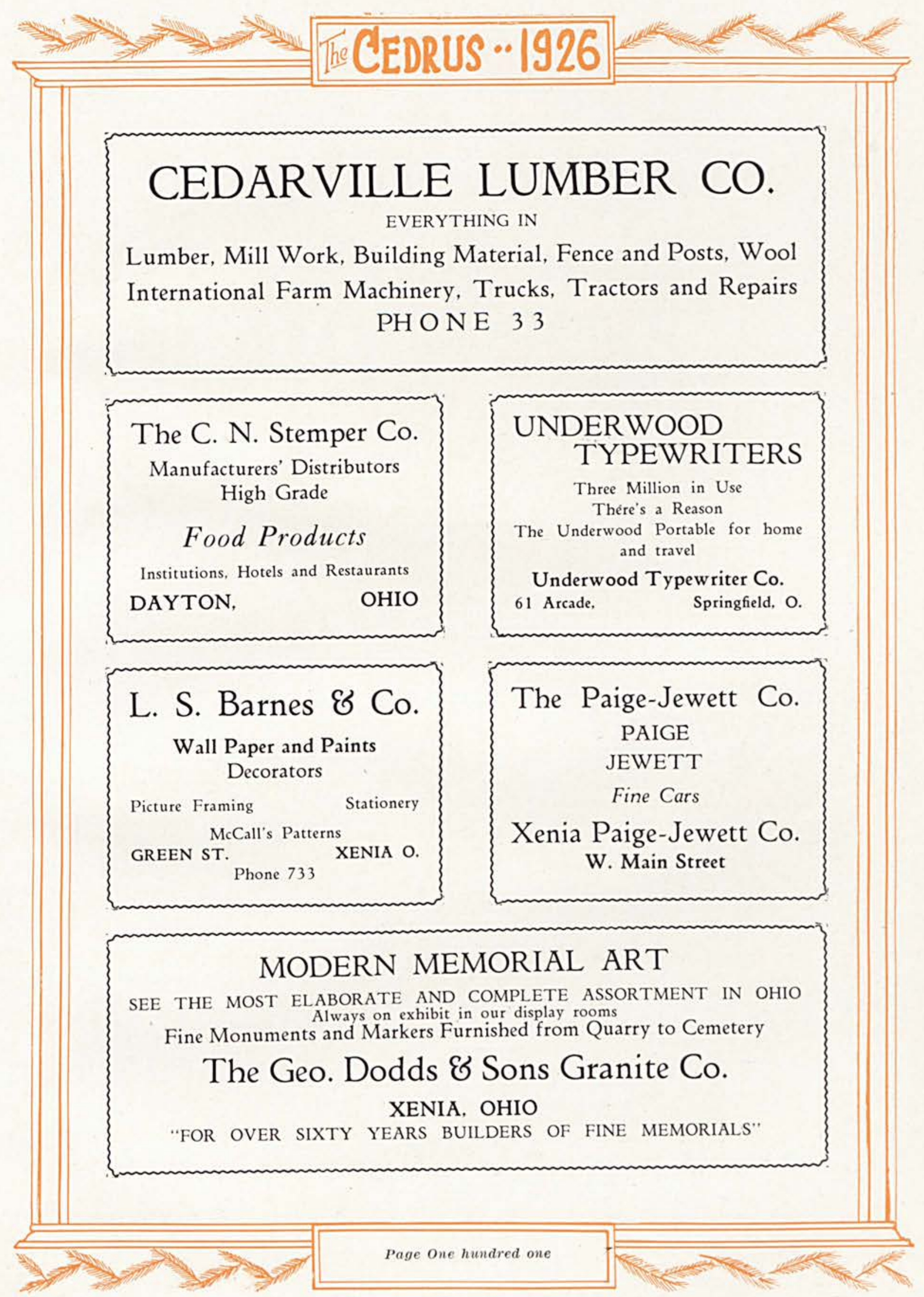




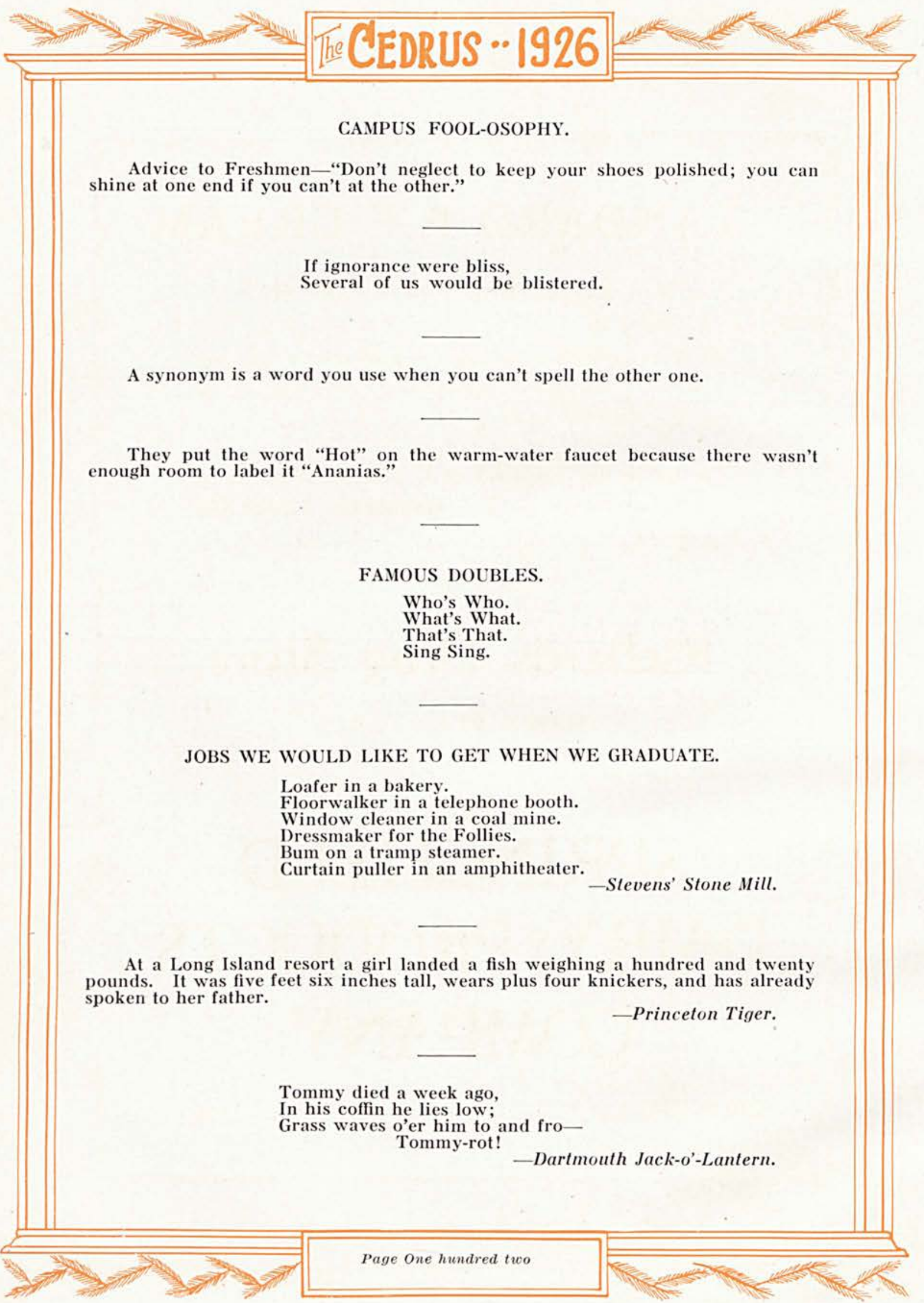





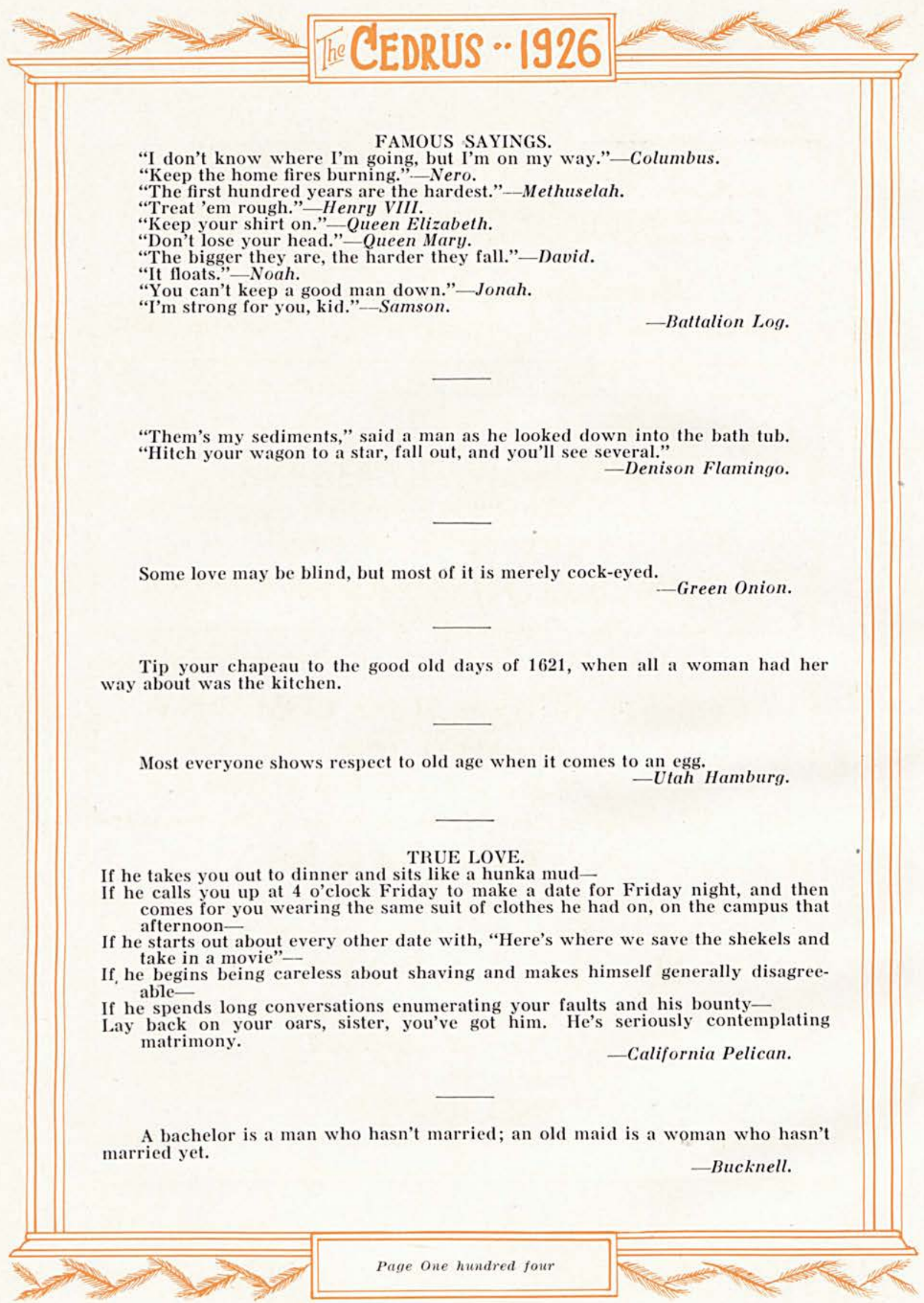




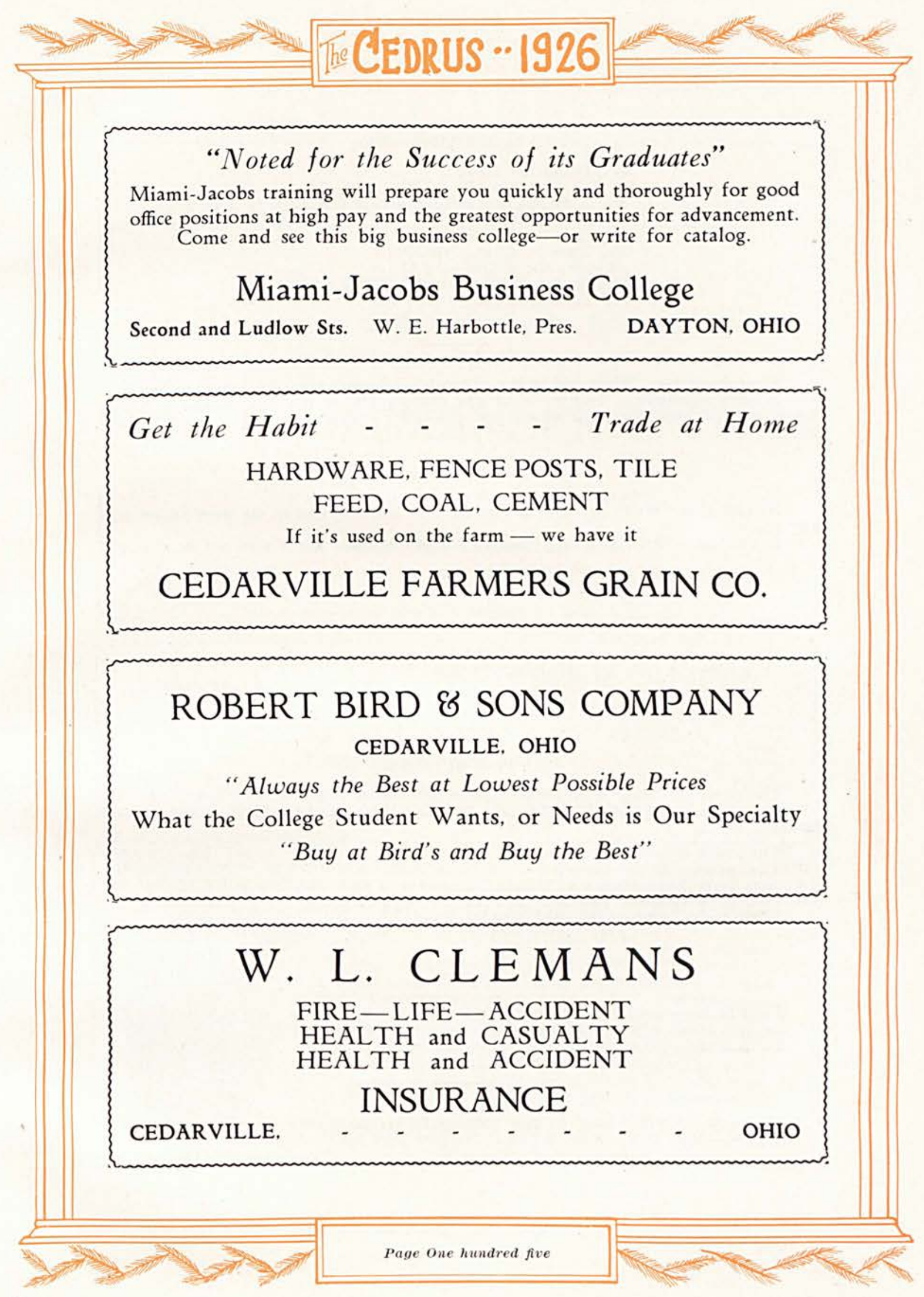




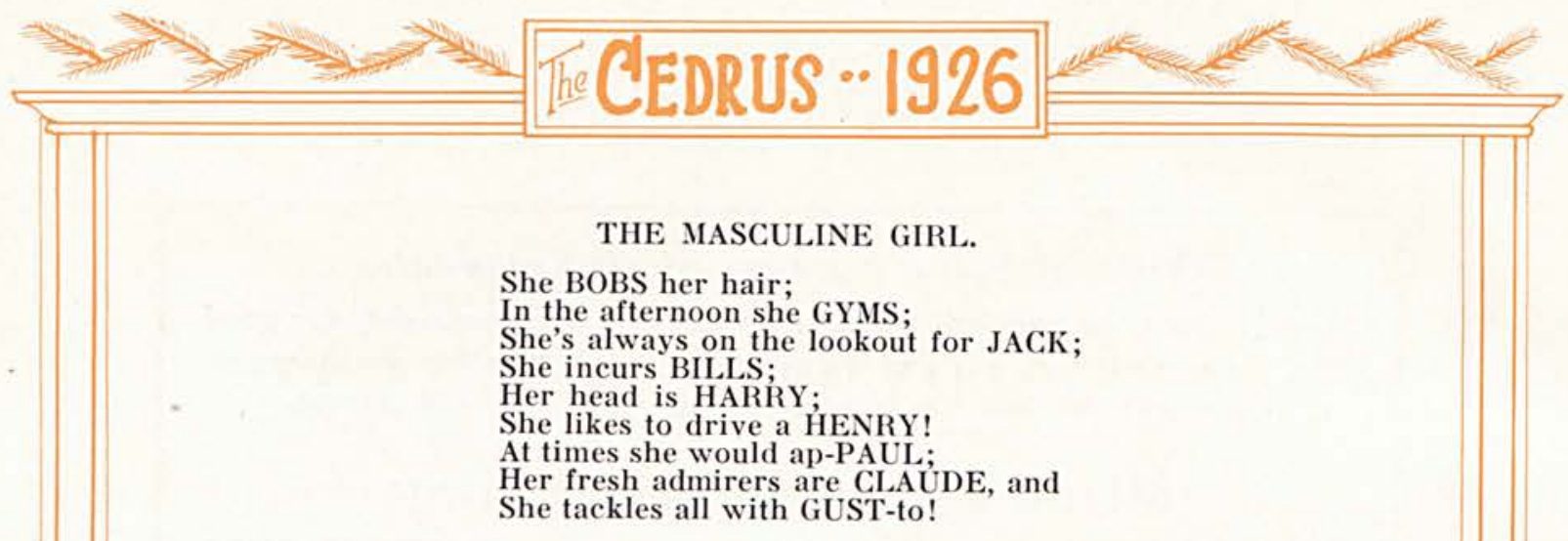

First Bachelor-“How old is Miss Spinster-doesn't she claim twenty-five?"

Second Bachelor- "Dunno what she claims, but at her last birthday party, when, they lighted the candles on her cake, five people were overcome by the heat."

Housewife - "We're going to get an electric washer, and so we won't need you any more.

Laundress-“All right, lady; but an electric washer don't give out no gossip."

"Coming in swimming, Tommy?"

“No; mother won't let me."

"Come on in; she'll never find it out."

"Yes, she will; it's my bath night to-night."

-London Passing Show.

\section{AS IT WOULD BE.}

The prof. was hauled up before the police judge, charged with speeding. To his dismay he found that the judge was no other than an old student whom he had flunked.

The judge assumed a solemn air. "Professor Smith," he said, "this is a very serious charge. But for the sake of the old school, I am going to let you off lightly. You may have your choice of taking the quiz you gave me five years ago, or ten years on the rock-pile! Choose!"

"Ten years," gasped the prof. and swooned.

—Kansas Sour Owl.

First Stude- "I just got a check from home."

Second Stude -"Pay me the five dollars you owe me, then."

First Stude- "Wait till I tell you the rest of my dream."

Mistress-"Mandy, how do you manage to get your pies so neatly crimped?" Mandy - "Oh, that's easy, ma'am. Ah just uses mah false teeth."

-Oklahoma Whirlwind.

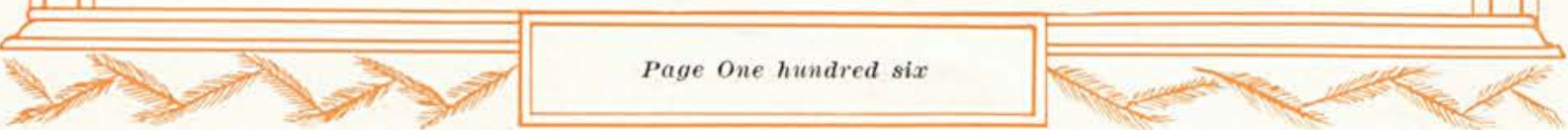




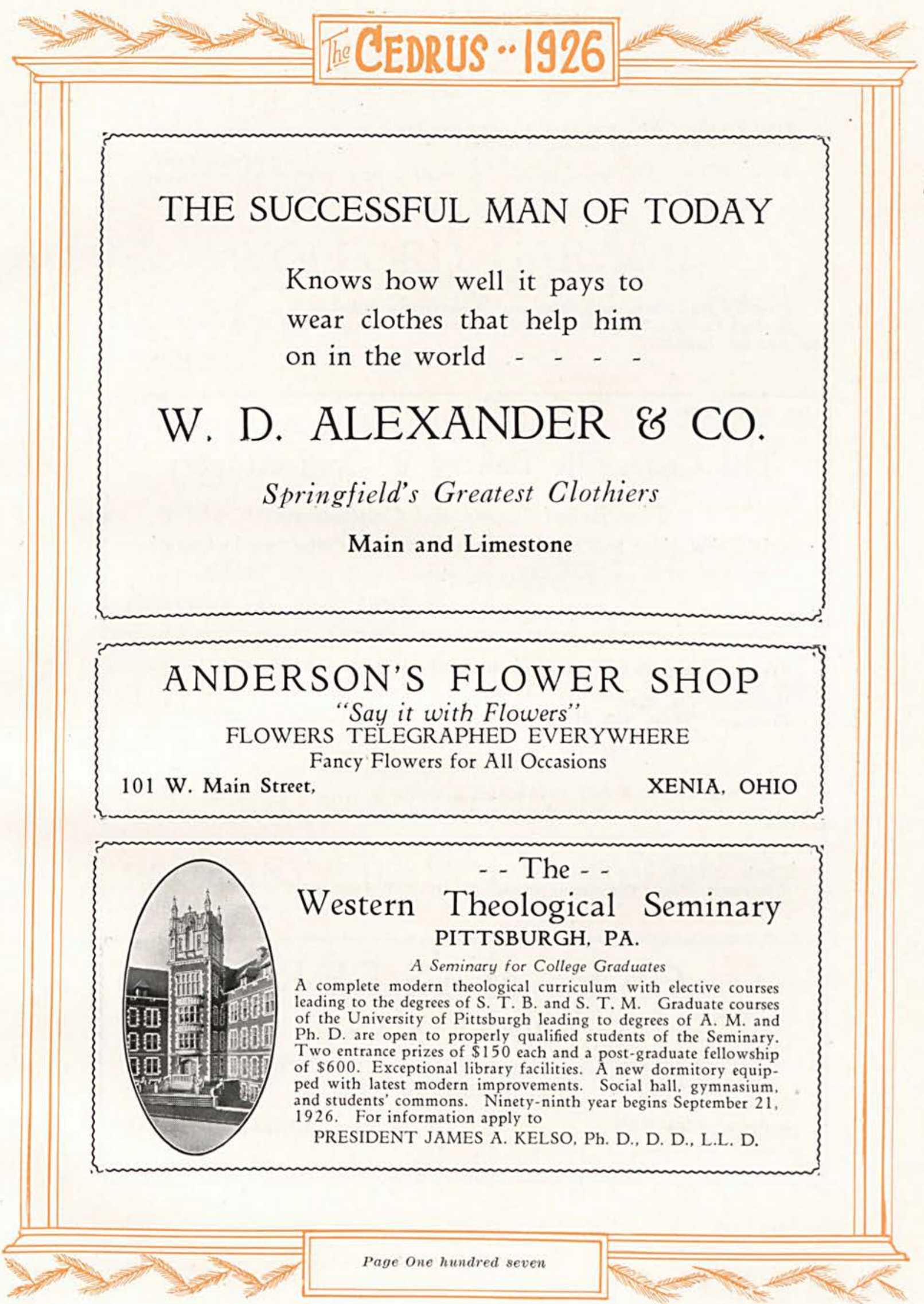




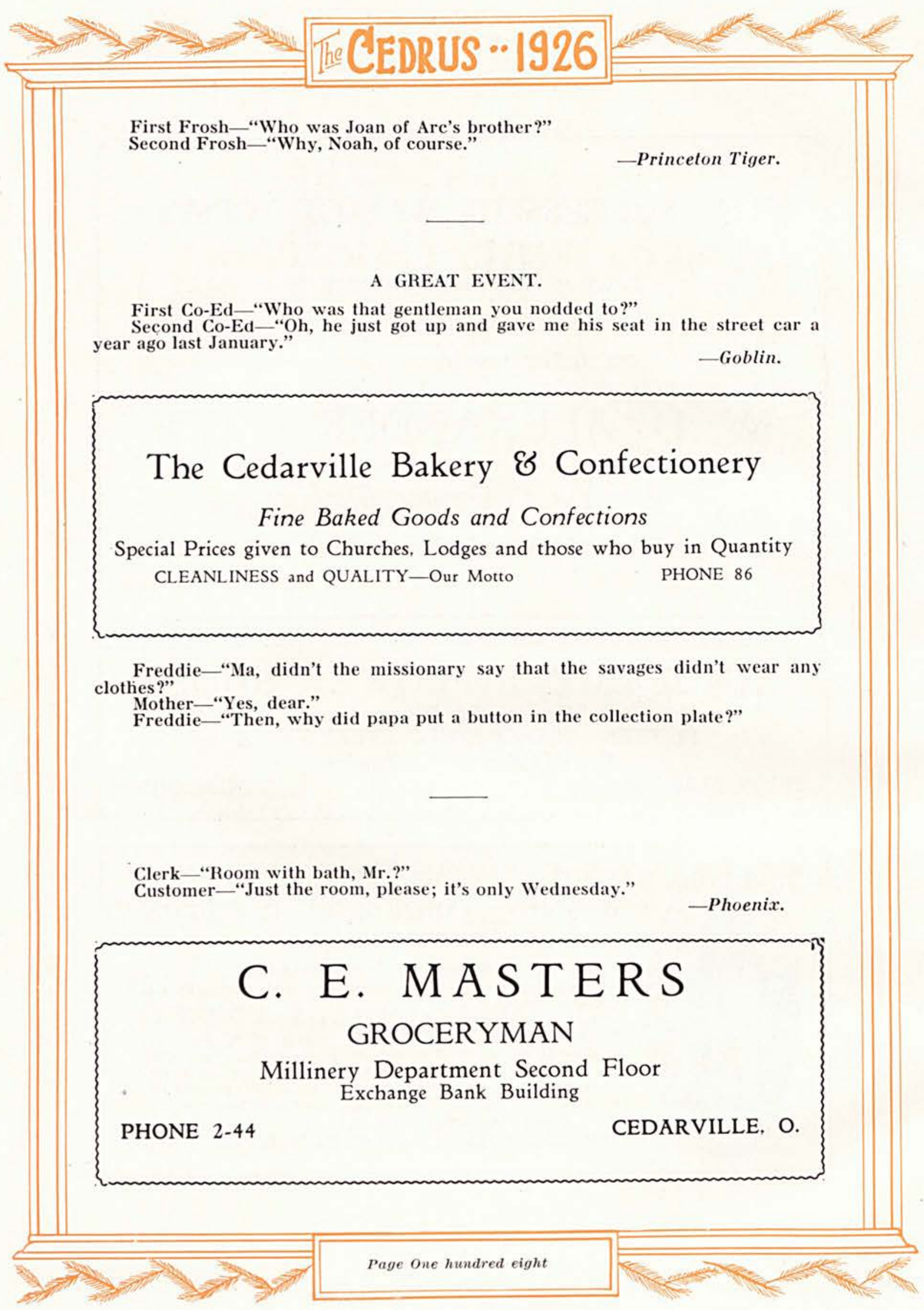




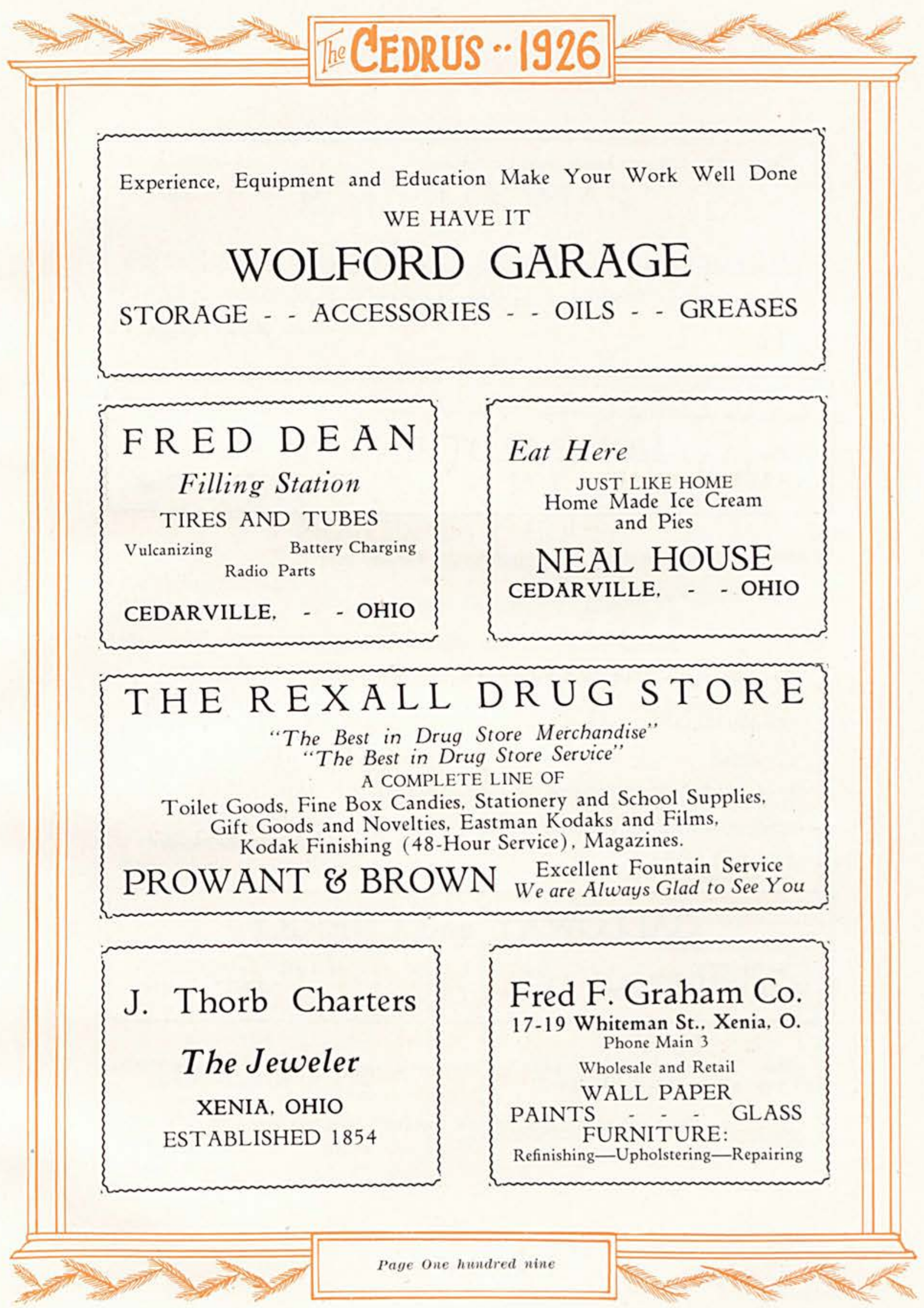




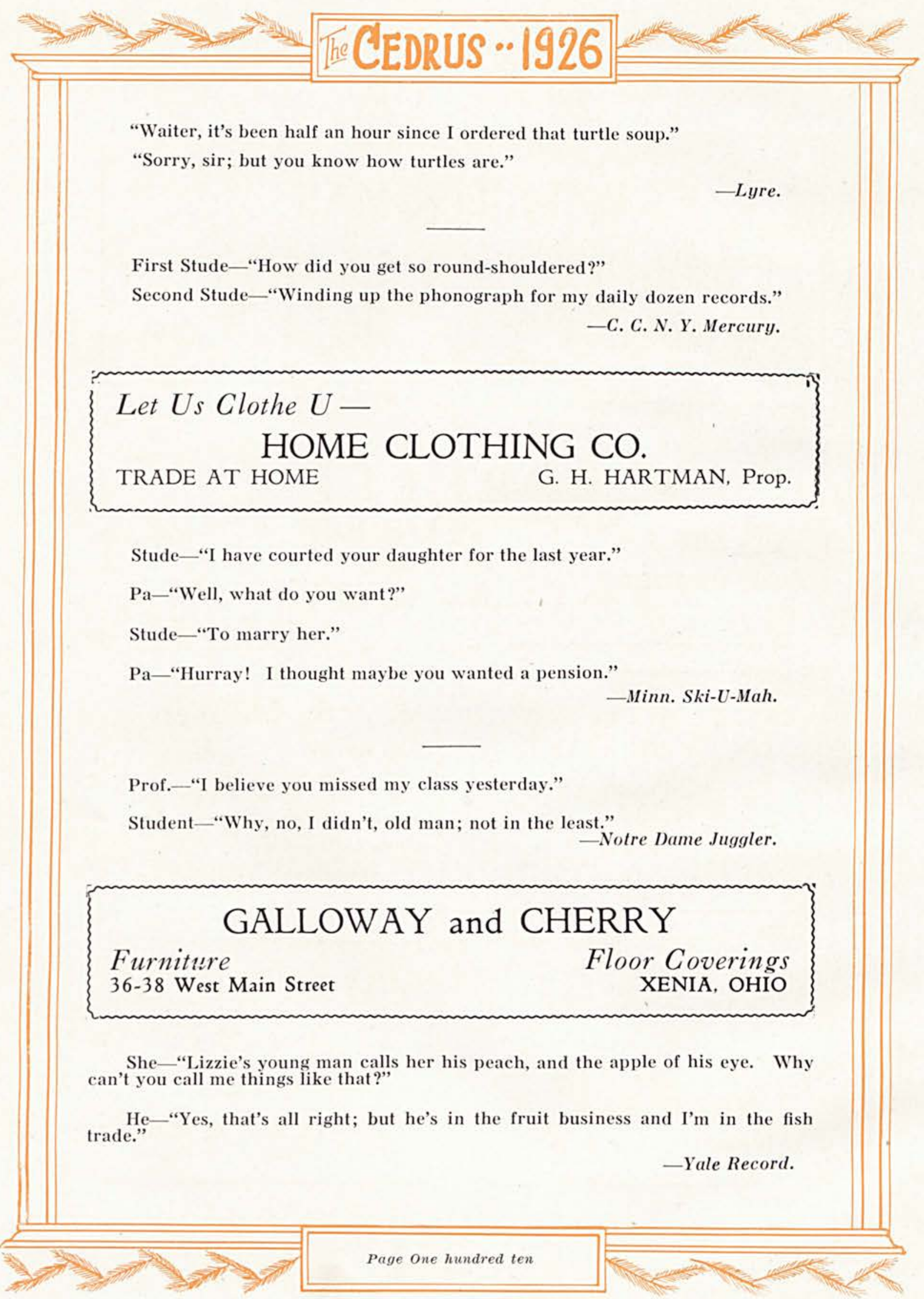




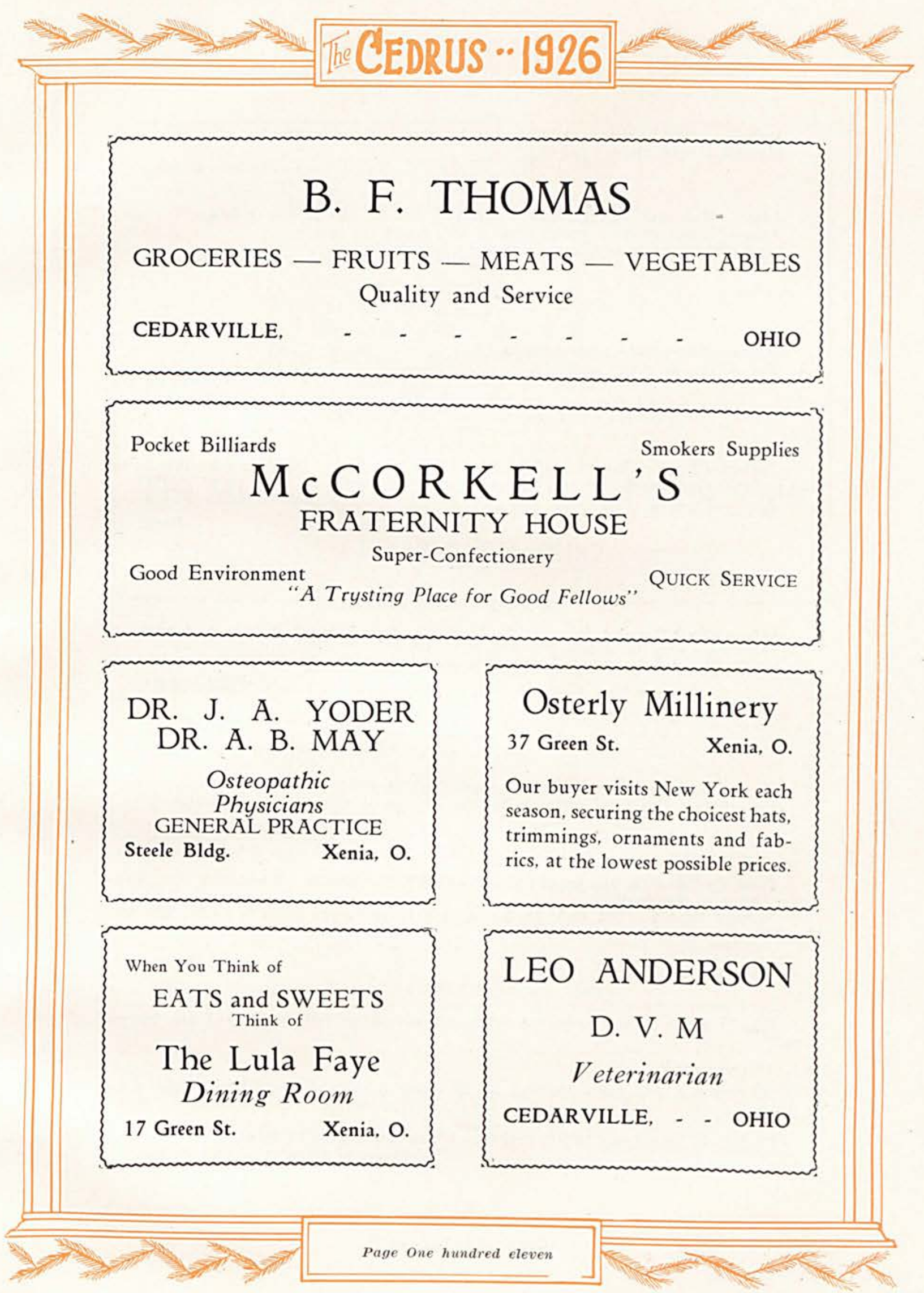




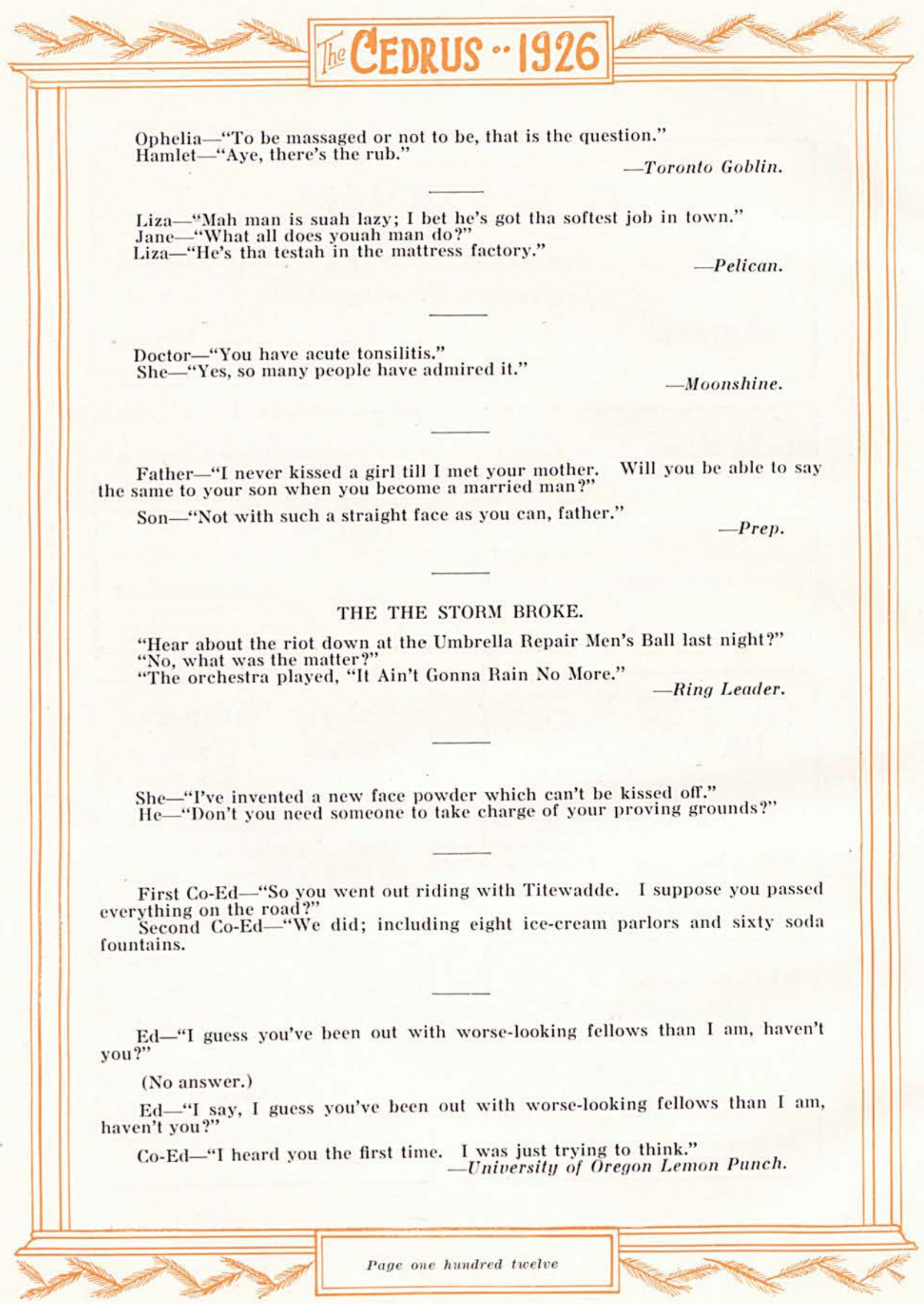




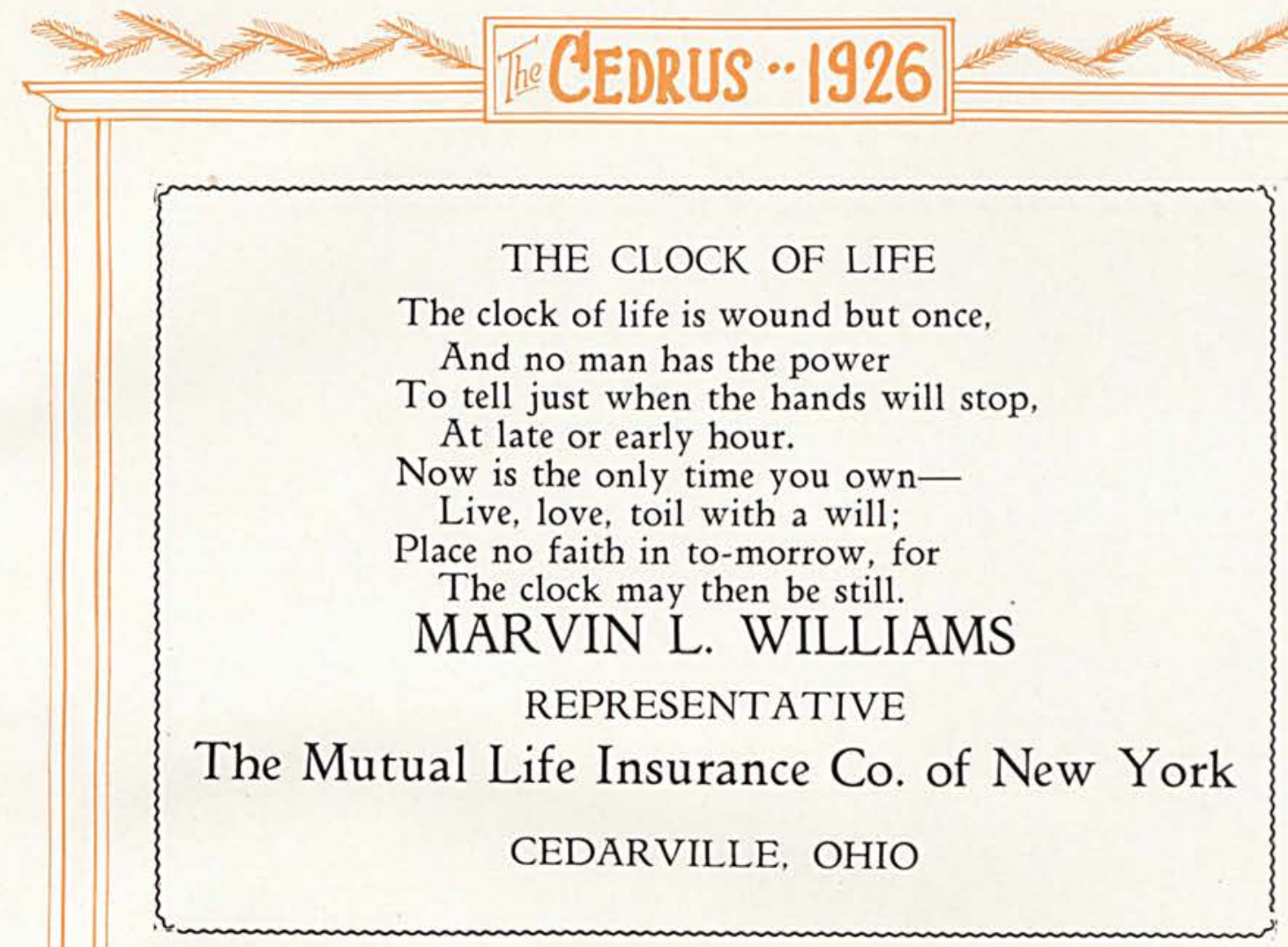

Irate Usher (to man in picture show looking, with the aid of a match, for something on the floor) - "Hey, put out the light! What are you looking for?"

Man With Light- "I'm looking for a piece of taffy I dropped."

Irate One-“You're causing all this trouble looking for a piece of taffy?"

M. W. L.- "But the taffy had my teeth in it."

Landlady - "Isn't this a good chicken?"

Boarder - "It may have been morally, but physically it's a wreck."

-Pitt Panther.

Samson-"Why did you send that poor boy back for your cold cream? He'll never find it.”

Delilah- "I only wanted to get the chap off my hands." -Princeton Tiger.

"Fadder, you told me you would give me a dollar efery time I got an A in collitch. Fadder, I made two last week."

"Vell, here's two dollars. Now quit studying so much. It's bad for you."

-Oklahoma Whirlwind. 

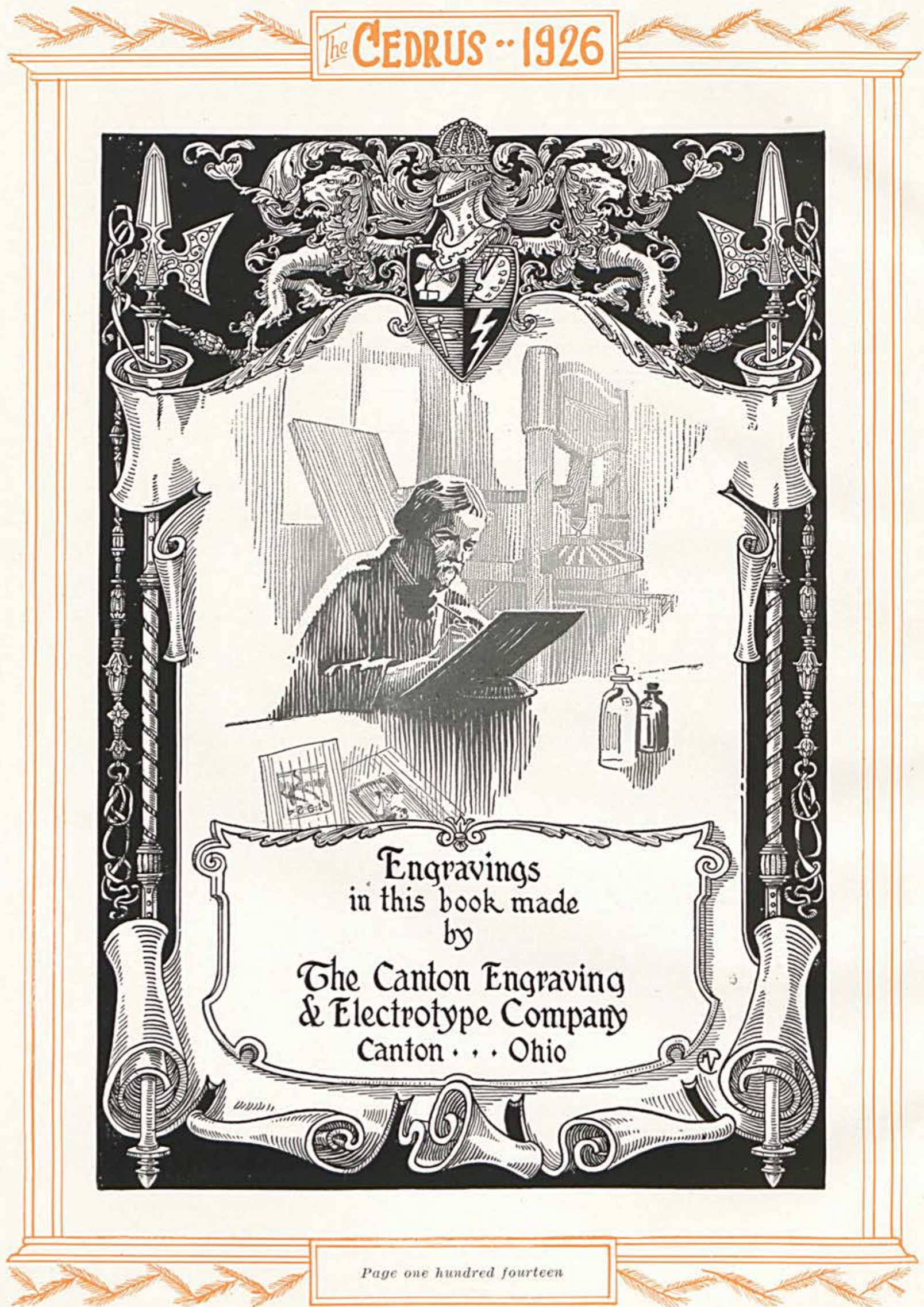


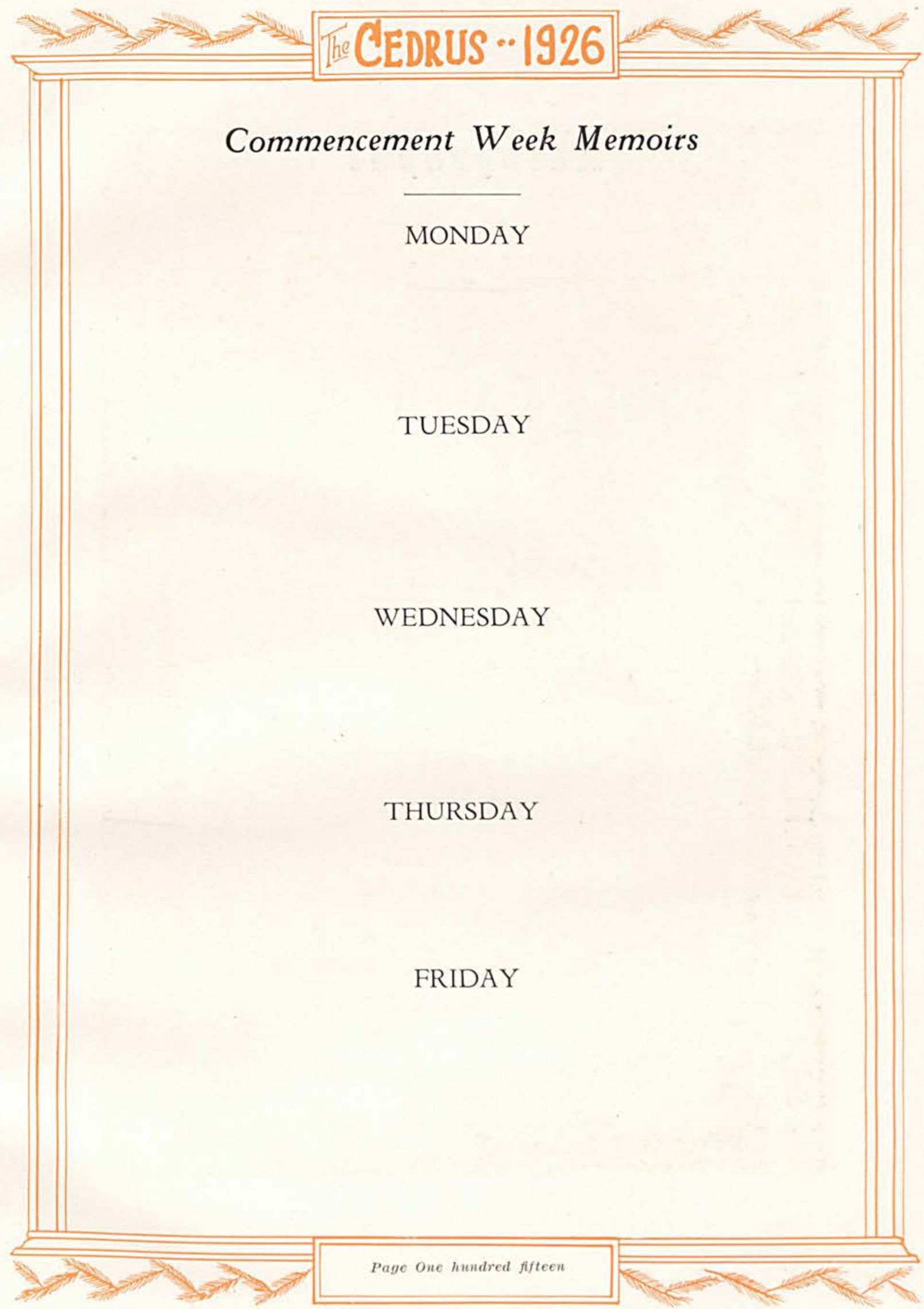




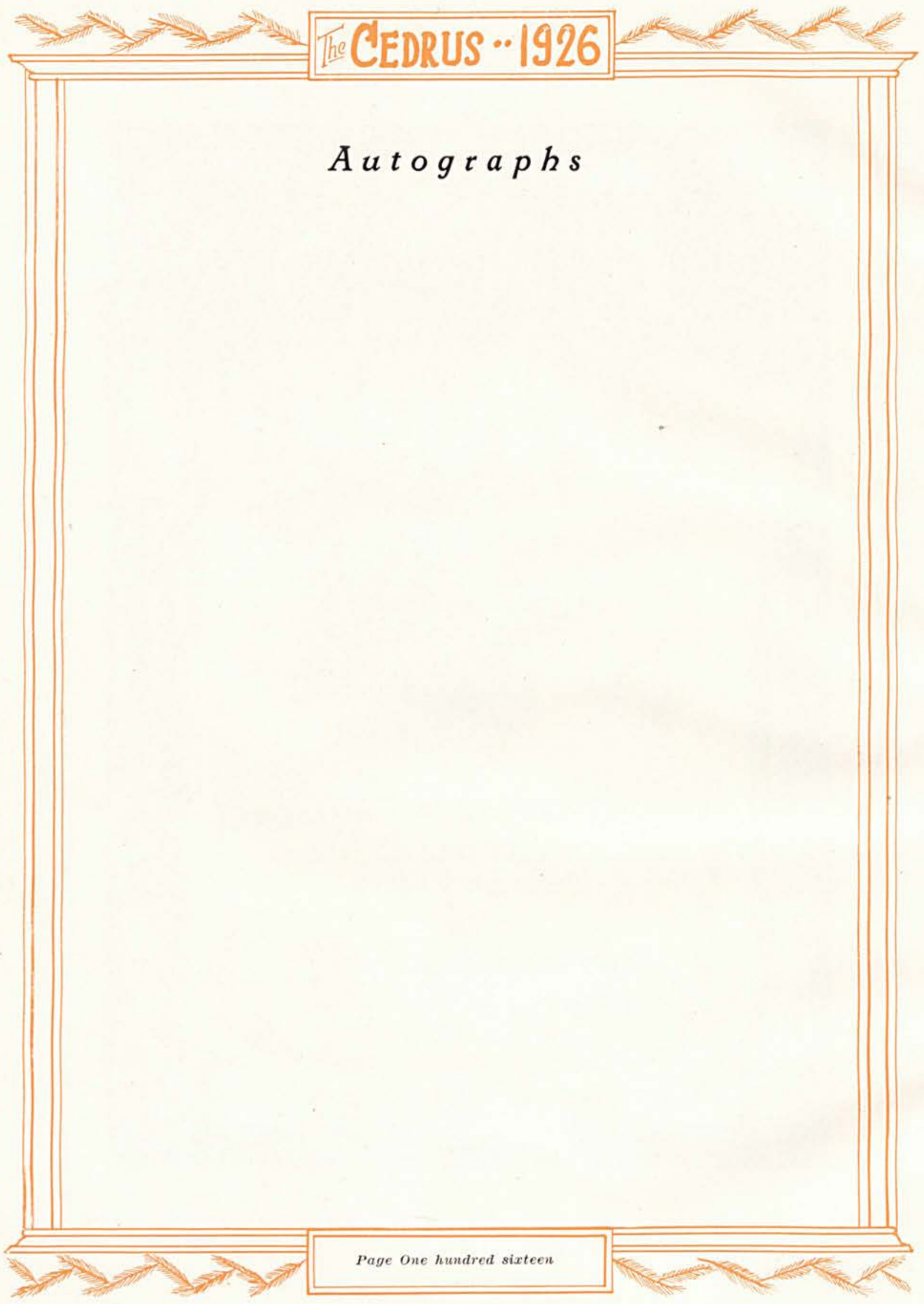




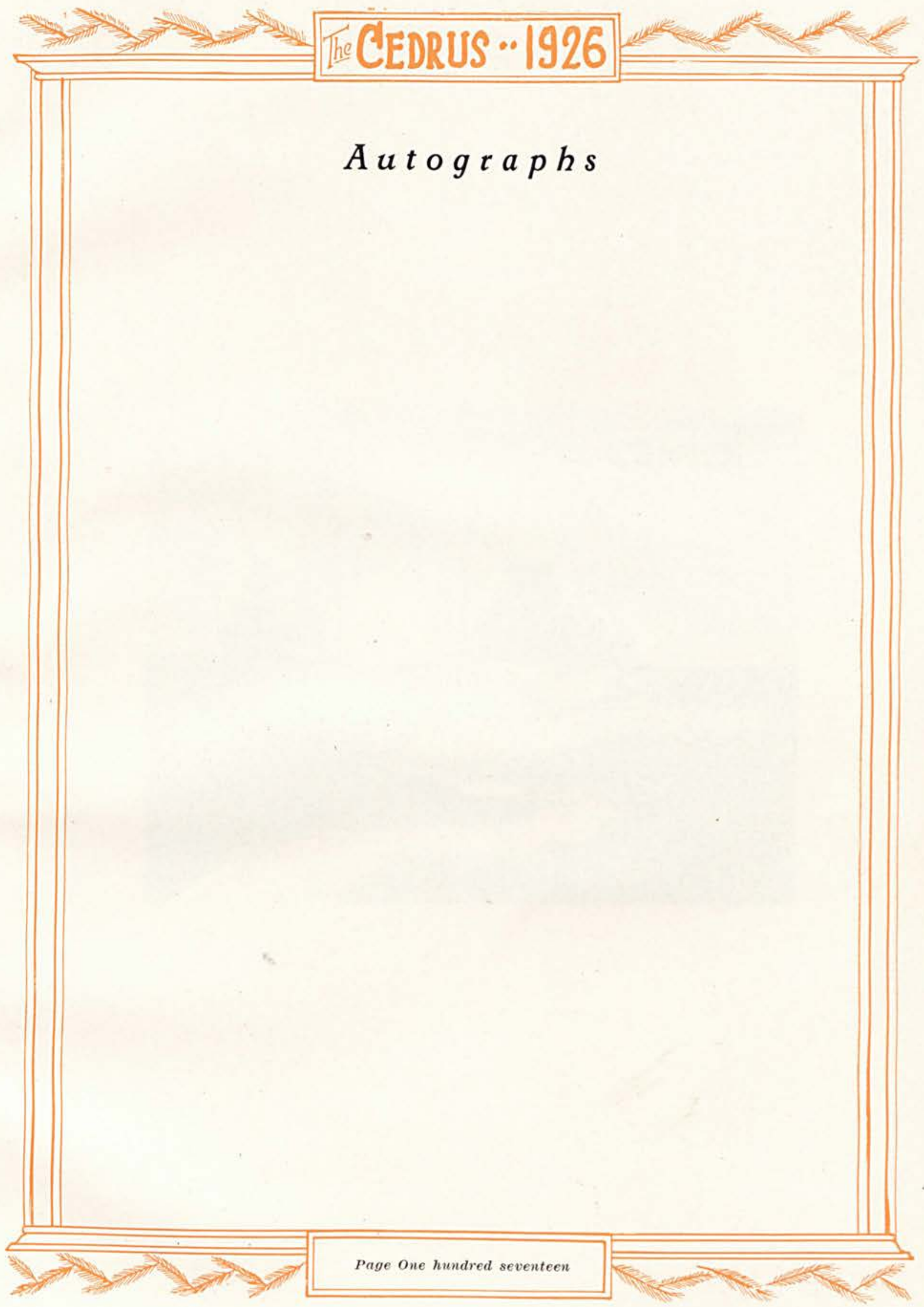



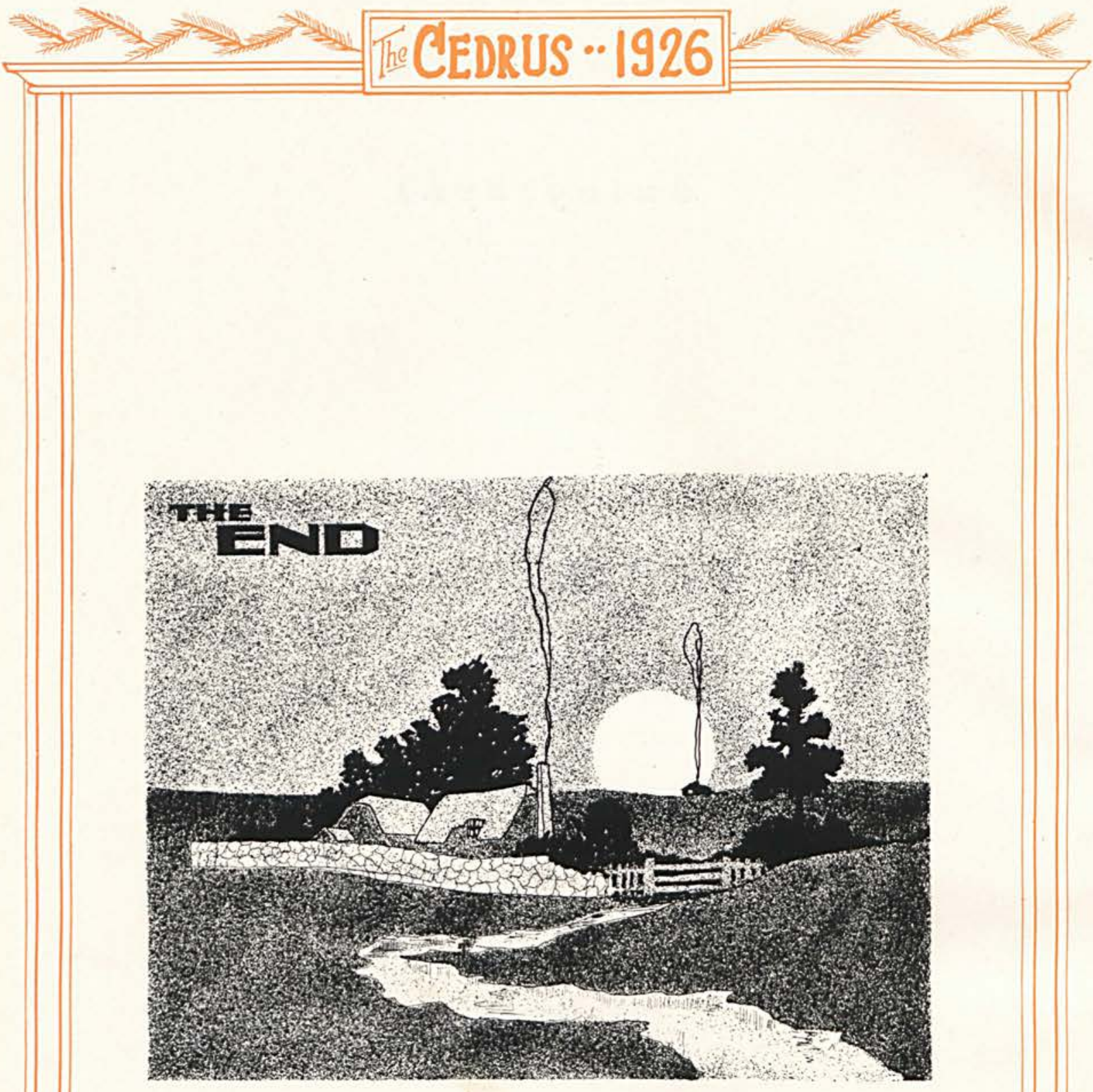



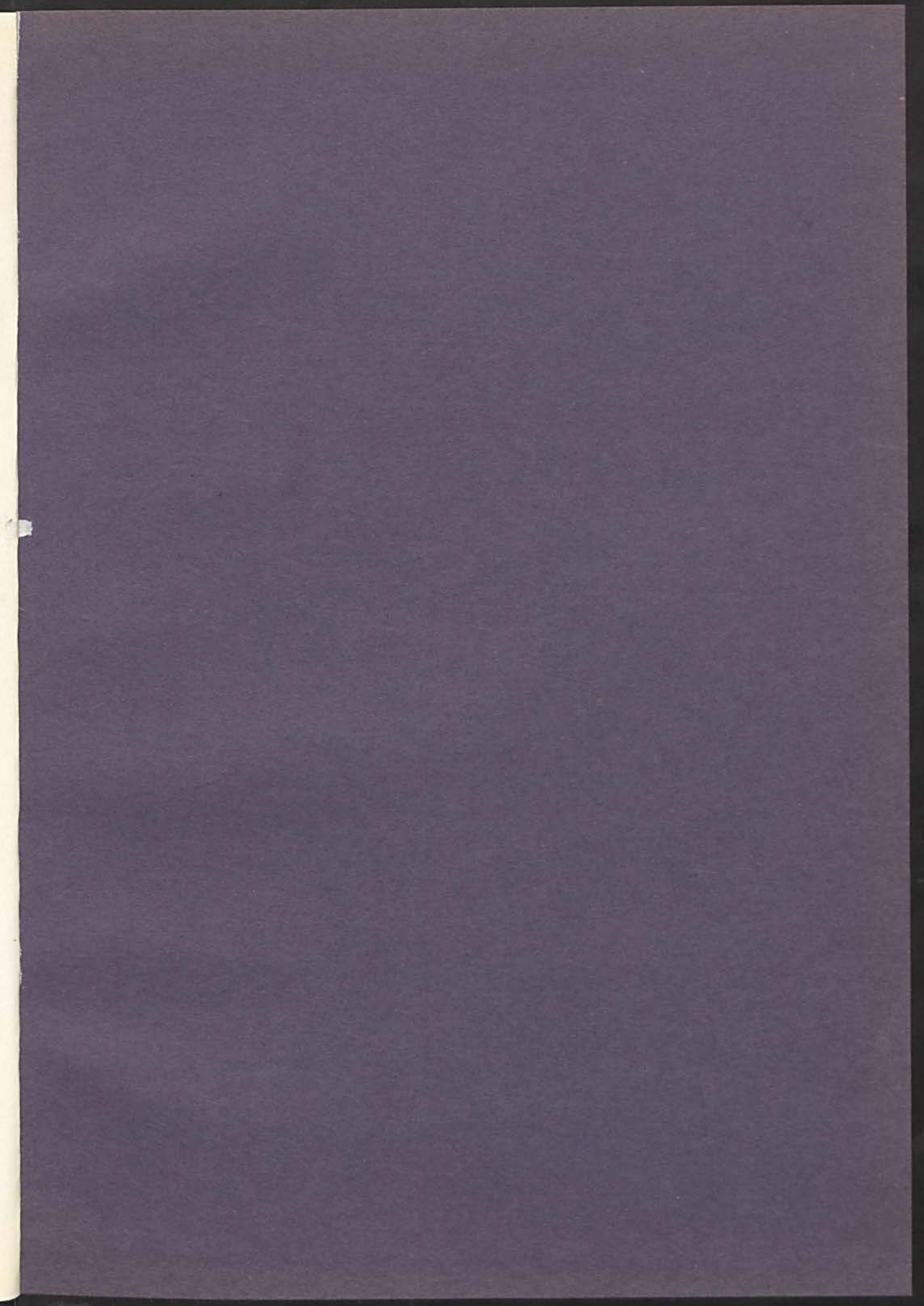


2 

